University of Pennsylvania Carey Law School

Penn Law: Legal Scholarship Repository

Faculty Scholarship at Penn Law

1983

\title{
Element Analysis in Defining Criminal Liability: The Model Penal Code and Beyond
}

Paul H. Robinson

University of Pennsylvania Carey Law School

Jane A. Grall

New Jersey Superior Court

Follow this and additional works at: https://scholarship.law.upenn.edu/faculty_scholarship

Part of the Criminal Law Commons, Criminal Procedure Commons, Legal History Commons, and the Public Law and Legal Theory Commons

\section{Repository Citation}

Robinson, Paul H. and Grall, Jane A., "Element Analysis in Defining Criminal Liability: The Model Penal Code and Beyond" (1983). Faculty Scholarship at Penn Law. 630.

https://scholarship.law.upenn.edu/faculty_scholarship/630

This Article is brought to you for free and open access by Penn Law: Legal Scholarship Repository. It has been accepted for inclusion in Faculty Scholarship at Penn Law by an authorized administrator of Penn Law: Legal Scholarship Repository. For more information, please contact PennlawIR@law.upenn.edu. 


\title{
Element Analysis in Defining Criminal Liability: The Model Penal Code and Beyond $\dagger$
}

\author{
Paul H. Robinson* \\ Jane A. Grall**
}

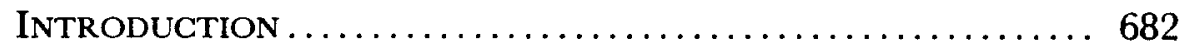

I. Refinements in the Definition of Criminal

LIABILITY .............................. 685

II. Element Analysis in Modern Codes: The Model

Penal Code Culpability Scheme ............... 691

A. Culpability Terms Defined in Relation to Each Objective

Element ............................... 694

B. Culpability Requirements Stated in an Offense Definition ... 699

C. Culpability Requirements Supplied by General Provisions ... 700

III. The Case for Element Analysis ............... 703

IV. Confusion and Ambiguities in Modern

Culpability Schemes ......................... 705

A. The Use of Undefined Culpability Terms ............ 705

B. Difficulties in Determining Whether an Objective Element Is

a Conduct, Circumstance, or Result Element ........... 706

C. Combining Conduct and Result or Conduct and Circumstance Elements in a Single Term .................... 709

D. Failure to Define Recklessness and Negligence with Respect to Conduct ................................... 710

E. Variations on Model Penal Code Section 2.02(3) (Requiring Recklessness Where Culpability Is Not

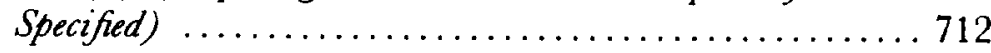

† (C) 1983, Paul H. Robinson.

* B.S. 1970, Rensselaer Polytechnic Institute; J.D. 1973, University of California, Los Angeles; LL.M. 1974, Harvard; Dipl. Leg. St. 1976, Cambridge. Professor of Law, Rutgers University, Camden.

** A.B. 1971, Trinity College (Wash., D.C.); J.D. 1981, Rutgers University, Camden. Member of the Bar of New Jersey. 
F. Conceptual and Practical Difficulties with Model Penal Code Section 2.02(4): Applying a Stated Culpability Term to All Elements of an Offense .................... 714

G. Conflict and Inconsistency Between Model Penal Sections 2.02(3) and 2.02(4): Element Analysis vs. Offense

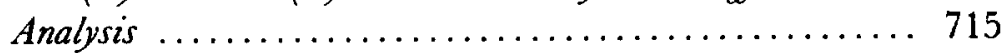

V. Element Analysis in Defining CRiminal Liability .. 719

A. A Proposed Scheme for Defining Offenses ............ 719

B. Element Analysis and Mistake ................. 725

C. Element Analysis in Complicity ................. 732

D. Element Analysis in Attempt .................. 744

E. Element Analysis in Conspiracy ............... 751

SumMary AND Conclusion ........................ 757 APPENDIX: ElEMENT ANALySIS Summaries (Charts III-VI) . . . . ......................... 759

\section{INTRODUCTION}

The pursuit of fairness and effectiveness has inspired and guided criminal code reformers of the past two decades. ${ }^{1}$ Because penal law protects the most important societal interests and authorizes the most serious sanctions the government may impose ${ }^{2}$ - the stigma of conviction, imprisonment, and even death-a criminal code, more than any other body of law, should be rational, clear, and internally consistent. Only a precise, principled code that sufficiently defines forbidden conduct can achieve its goals of condemnation and deterrence. ${ }^{3}$ Such a code gives citizens fair warning of what will constitute a crime, ${ }^{4}$ limits governmental discretion in determining whether a particular individual has violated the criminal law, ${ }^{5}$ and provides the distinctions among degrees of harm and degrees of culpability that create the foundation of a fair sentencing system. ${ }^{6}$

1. See generally Kadish, Codiffers of the Criminal Law: Wechsler's Predecessors, 78 CoLuM. L. Rev. 1098 (1978); Wechsler, The Challenge of a Model Penal Code, 65 HaRv. L. REv. 1097 (1952).

2. Kadish, supra note 1, at 1098.

3. See generally Model Penal Code $\$ 1.02(1)$, (3) (Proposed Official Draft 1962) (Purposes; Principles of Construction); Hart, The Aims of the Criminal Law, 23 LAW \& CONTEMP. Probs. 401 (1958).

4. See notes $96-97$ infra.

5. See notes 97-98 infra.

6. Most modern sentencing systems rely upon the grade of the offense to determine the guideline or fixed sentence. See, e.g., ME. REV. STAT. ANN. tit. 17.A, § 1252 (1983); N.J. Stat. AnN. § 2C:44-1(f) (West 1982). See generally S. REP. No. 97-307, 97th Cong., 1st Sess. 955-77 (1981); P. O'Donnell, M. Churgin \& D. Curtis, Toward a Just and Erfective Sentencing System: Agenda for Legislative Reform (1977); The Twentieth Cen- 
American criminal law has advanced significantly towards providing such precision, clarity, and rationality, owing in large part to the Model Penal Code. The common law and older codes often defined an offense to require only a single mental state. ${ }^{\top}$ Under this "offense analysis," one spoke of intentional offenses, reckless offenses, and negligent offenses. The general culpability provisions of the Model Penal Code, in contrast, recognize that a single offense definition may require a different culpable state of $\operatorname{mind}^{8}$ for each objective element ${ }^{9}$ of the offense.

The majority of American jurisdictions have adopted criminal codes that incorporate this Model Penal Code innovation by requiring courts to apply an element analysis to each offense and theory of liability. ${ }^{10}$ Indeed, element analysis may have constitutional signifi-

tury fund Task Force on Criminal Sentencing, Fair and Certain Punishment (1976). Both the degree of harm and the level of culpability are relevant to the grade of an offense. See, e.g., ME. REv. Stat. ANN. tit. 17-A, $\$ \S 207-208$ (1983) (degree of assault increases with severity of injury caused); N.J. STAT. ANN. $\$ 2$ C:2-2(e) (West 1982) (when grade or degree of offense depends upon the degree of culpability, the grade or degree shall be the lowest for which the determinative kind of culpability is established).

7. The phrases "mental state" and "culpable state of mind" are used throughout this article to refer to any one of the four levels of culpability-purpose, knowledge, recklessness, and negligence. While some might criticize this usage on the ground that negligence is not a state of mind, see, e.g., G. Williams, Criminal LaW: The General Part $§ 14$, at 31 (2d ed. 1961), others have found the phrase a useful shorthand device. See, e.g., G. Fletcher, RETHINking Criminal LAW $\$ 6.8 .1$, at 508-10 (1978); W. LAFAVE \& A. SCOTT, HANDBoOK ON CRIMINAL LAW $\S 2$, at $5 \& \mathrm{n} .2$ (1972). More important, since negligence refers to a state of unawareness, see text accompanying notes $58-63$ infra, to describe it as a state of mind seems appropriate.

This usage also comports with current statutory language. Hawaii, for example, employs the phrase "state of mind" this way. HaWAII REV. STAT. $\S 702-204$ (1976); accord DEL. CODE AnN. tit. 11, § 231 (1974 \& Cum. Supp. 1982); ME. Rev. STAT. ANN. tit. 17-A, §§ 34-35 (1983); see also ALA. CODE $\S 13 A-2-1(6)$ (1982) ("culpable mental state" means intentionally, knowingly, recklessly, or with criminal negligence); ARIZ. REV. STAT. ANN. § 13-105(5) (Supp. 1982-1983); Colo. Rev. STAT. § 18-1-501(4) (1978); ConN. Gen. STAT. ANN. § 53a-5 (West 1972); Criminal Code of 1961, § 4-3, Ill. ANN. STAT. ch. 38, $\$ 4-3$ (Smith-Hurd 1972); KY. Rev. Stat. \$501.010(1) (1975); Mo. ANN. Stat. § 562.016(1) (Vernon 1979); N.Y. PENAL LaW \$15.00(6) (McKinney 1975); OHIO Rev. Code ANN. $\$ \S 2901.21$ (A)(2), (C)(3) (Page 1982); Or. Rev. STat. § 161.085(6) (1981); Tex. Penal Code ANN. $\$ 6.02$ (d) (Vernon 1974); see also S. 1437, 95th Cong., 1st Sess. $\$ 302$ (1977).

8. See note 7 supra.

9. The term "objective element" refers to a conduct, result, or circumstance element of an offense. See text accompanying note 50 infra.

10. See Ala. Code $\S \S 13 A-2-2$ to $-2-4$ (1982); Alaska STAT. $\$ \S 11.81 .600-610, .900$ (a) (Supp. 1982); ARIZ. REv. STAT. ANN. §§ 13-105(5), -202 (1978 \& Supp. 1982-1983); ARK. STAT. ANN. $\S \S 41-202$ to -204 (1977); Colo. REv. STAT. $\S \S 18-1-501(3),-501(5)-(6),-501(8)$, -503 (1978); Conn. Gen. Stat. ANN. $\S \S 53 a-3(11)-(14),-5$ (West 1972); Del. Code AnN. tit. 11, $\$$ 231, 251-253 (1979 \& Supp. 1982); Hawall REV. STAT. $\$ \S 704-204,-206$ to $-208,-212$ to -213 (1976); Criminal Code of $1961, \S \S 4-3$ to $-7,-9$, ILL. ANN. STAT. ch. $38,4-3$ to $-7,-9$ (Smith-Hurd 1972); KY. REv. STAT. $\$ \$ 501.010(1)$, .020, .030(2)-.050 (1975); ME. REv. 
cance. Mullaney v. Wilbur, ${ }^{11}$ Patterson v. New York, ${ }^{12}$ and Jackson v. Virginia $^{13}$ require the prosecution to carry the burden of persuasion and the burden of production for all "elements of the offense."14 Imple-

STAT. ANN. tit. 17-A, $\S \S 34-35$ (1982); Mo. ANN. STAT. $\S \S 562.016, .021, .026$ (Vernon 1979); MONT. Code ANN. $\$ \S 45-2-101(33)$, (37), (58), -103 to-104 (1981); N.H. Rev. STAT. ANN. § 626:2 (1974); N.J. STAT. ANN. § 2C:2-2 (West 1982); N.Y. Penal LaW $\S \$ 15.00(6)$, $.05-.15$ (McKinney 1975); N.D. Cent. Code $\S 12.1-02-02$ (1976); Ohio Rev. Code ANN. $\S \S 2901.21-.22$ (Page 1982); OR. REv. STAT. $\$ \S 161.085(6)-(10), .095(2), .105-.115$ (1981); 18 Pa. Cons. Stat. ANn. $\S \S 302,305$ (Purdon 1973); Tex. Penal Code AnN. $\S \S 6.02-.03$ (Vernon 1974); UTAH CODE ANN. $\$ \S 76-2-101$ to - 104 (1978); WASH. REV. CODE ANN. \$ 9A.08.010 (1977); see also S. 1437, 95th Cong., 1st Sess. $\$ \S 302-303$ (1977). These culpability provisions evince a variety of levels of commitment to, or understanding of, "element analysis." See generally notes 103-82 infra and accompanying text. In addition to the jurisdictions that have adopted an element analysis approach to criminal liability, nine others have emulated the Model Penal Code by defining culpability terms in their codes, thereby taking a step toward element analysis. See note 49 infra.

11. In Mullaney v. Wilbur, 421 U.S. 684 (1974), the Supreme Court held that Maine's practice of requiring the defendant to carry the burden of persuasion for the heat of passion defense, which reduces liability from murder to manslaughter, violated the due process clause. Id. at 704.

12. In Patterson v. New York, 432 U.S. 197 (1977), the Supreme Court upheld New York's practice of requiring the defendant to establish extreme emotional disturbance by a preponderance of the evidence. In both Mullaney and Palterson, the court relied on In re Winship, 397 U.S. 358, 364 (1970), which required proof beyond a reasonable doubt of each fact necessary to establish a crime. See 421 U.S. at $697-701 ; 432$ U.S. at 208-11; see also note 14 infra.

13. In Jackson v. Virginia, 443 U.S. 307 (1979), the defendant challenged the suffciency of the evidence supporting his state court conviction. The Supreme Court found that Jackson's challenge raised a federal constitutional claim cognizable in a federal habeas corpus proceeding. Id. at 321 ; see note 14 infra.

14. The Paltersan court distinguished the Maine and New York practices, see notes 11-12 supra, stating that the former required the defendant to disprove a "part of the definition" of the offense ("absence of provocation"), 432 U.S. at 197, 215-16, while the latter did not require proof of a fact that "serve[s] to negative any facts of the crime." Id. at 206-07. The Court went on to hold that "the Due Process Clause requires the prosecution to prove beyond a reasonable doubt all of the elements included in the defnition of the offense." Id at 210 (emphasis added). The requirement of proof of each element beyond a reasonable doubt is often codified. See note 213 infra.

The Jackson court defined the standard of review for a claim that the evidence is insufficient to support a conviction: "[T] in the light most favorable to the prosecution, any rational trier of fact could have found the essential elements of the crime beyond a reasonable doubt." 443 U.S. at 319 (emphasis omitted). This standard requires the prosecution to introduce the specified quantum of evidence or risk reversal; it imposes, in effect, a burden of production on the prosecution for each element of the offense.

These constitutional mandates seem hollow where offense analysis prevails. For example, an Illinois court recently held that a trial judge need not instruct the jury on the elements of theft, where burglary with intent to commit theft is charged. People v. Johnson, $98 \mathrm{III}$. App. 3d 228, 424 N.E.2d 610 (1981). Many of the elements of theft are elements of burglary in such a case; element analysis reveals the necessity for and permits instructions on all relevant elements. 
mentation of these constitutional demands requires a full and accurate description of all elements.

Despite the importance of the Model Penal Code for precision and clarity in criminal law codification, its overwhelming adoption by the states, and its constitutional significance, neither the Model Penal Code drafters nor the legislatures and courts of jurisdictions following the Code's lead fully appreciate the dramatic nature of the Code's innovation and its far-reaching implications.

This Article seeks to illustrate the importance of the Model Penal Code's "element analysis" concept to a rational, clear, and just system of criminal law. It points out the vestiges of "offense analysis" remaining in the Code and demonstrates how these remnants produce ambiguities in the formulation of offense definitions and in the major doctrines of inculpation. It aims to bring the promise of element analysis to fruition. After a brief review in Part I of the theoretical developments leading to this concept, Part II examines the Model Penal Code provisions that commit the Code to element analysis. Part III summarizes the virtues of such an approach. The Code's implementation of element analysis is, however, defective in many respects. Close scrutiny reveals it to be unworkable in some instances and altogether ignored by courts in others. But these criticisms, described in Part IV, are not meant to impugn the genius of the initial thought. It is the concept of element analysis that facilitates the criticism. Part V proposes a specific culpability scheme for defining offenses and suggests reformulations of the major doctrines of inculpation. These proposals demonstrate the full potential of the concept of element analysis.

\section{Refinements in the Definition of Criminal Liability}

In his classic study of mens rea, Professor Sayre concludes that in early law "mens rea doubtless meant little more than a general immorality of motive." 15 The early conception of mens rea has also been described as "a general notion of moral blameworthiness," 16 an "evilmeaning mind,"17 and a "vicious will."18 In Regina $v$. Prince, ${ }^{19}$ for example, the defendant's reasonable belief that the girl was over six-

15. Sayre, The Present Signification of Mens Rea in the Criminal Law, in HARVARD LeGal EsSays 399, 411-12 (1934).

16. Remington \& Helstad, The Mental Element in Crime-A Legislative Problem, 1952 Wis L. REV. 644, 648-49.

17. Morissette v. United States, 342 U.S. 246, 251 (1952)

18. 4 W. BLACKSTONE, COMMENTARIES *21.

19. 2 L.R.-Cr. Cas. Res. 154 (1875). 
teen did not provide a defense to the crime of taking a girl under sixteen from the possession of her father. The defendant had the necessary mens rea, the court reasoned, because even if the girl had been over sixteen, the defendant's conduct would have been "wrong." 20

Many writers have since quarreled with aspects of Sayre's characterization, ${ }^{21}$ although most agree that the view of mens rea generally has shifted from a vague notion of wickedness to a more definite requirement of a specific state of mind. ${ }^{22}$ "[M]ens rea to-day means something quite different from immorality of motive." 23 It means "a particular kind of intent . . . a criminal intent, that is, the intent to

20. Id. at 173-76 (1875) (because the act was wrong, the absence of mens rea did not prohibit the imposition of the criminal sanction; the defendant took the young woman at the risk of her turning out to be under sixteen). In similar fashion, this broad conception of mens rea as moral blameworthiness gave rise to doctrines that imposed liability for unintended consequences of unlawful acts. See Remington \& Helstad, supra note 16, at 655-58 (discussing moral blameworthiness and the doctrines of felony murder and misdemeanor manslaughter). Hall, too, attributes the evolution and decline of felony murder and misdemeanor manslaughter to refinements in the concept of mens rea. J. Hall, General Principles of Criminal Law 129-30 (2d ed. 1960).

21. For example, Hall, a vigorous critic, takes issue with Sayre's historical analysis, particularly Sayre's emphasis on the significance of motive in early law. See J. HALL, supra note 20 , at 77-83. In addition, Hall criticizes Sayre, as well as his predecessors and followers, for "their failure to appreciate the significance of the general characteristics of the many specific criminal intents." Id. at 103 (footnote omitted). As Hall notes, Sayre was not the first to dispute the conclusion that mens rea defies general description. See Turner, The Mental Element in Crime at Common Law, 6 CAMBridGE L.J. 31,38 (1936) (objecting to Stephen's emphasis of the dissimilarity of the mens rea for various offenses, see note 22 infra, and pointing to common elements).

In contrast to Sayre, Hall stresses the "common, 'essential' characteristic [of mens rea] expressed in the voluntary doing of a morally wrong act." J. HALL, supra note 20, at 103 . Moreover, Sayre and the authors who share his view, see note 22 infra, do not explicitly define mens rea in normative terms, as does Hall. Many have criticized the absence of moral concerns in Sayre's approach. See G. FLETCHER, supra note 7, \$6.2, at 399; J. HALL, supra note 20 , at 71 , 103; Turner, supra note 21 , at 38 . But, in fact, Sayre does not attempt to equate mens rea with moral blameworthiness. In Sayre, as in this article, mens rea describes only a subjective state of mind required by the definition of an offense. One who has the necessary mens rea may nonetheless be blameless because of a general defense, such as insanity, selfdefense, or duress, that precludes moral culpability. By adopting a narrow concept of mens rea, which refers only to elements of an offense definition, one does not necessarily reject a normative view of criminal liability.

22. Sayre, supra note 15 , at 412 . Stephen also came to the conclusion that mens rea did not exist apart from the definition of particular crimes. 2 J.F. STEPHEN, A HiSTORY OF THE Criminal LaW OF ENGLAND 94-95 (1883). Sayre's description of mens rea is echoed today. Williams writes: "[Mens rea] refers to the mental element necessary for the particular crime, and this mental element may be either intention to do the immediate act or bring about the consequence or (in some crimes) recklessness as to such act or consequence." G. WILliams, supra note $7, \S 14$, at 31 ; see also J. HALL, supra note 20, at $71-72$ (discussing various scholars and members of the judiciary who view mens rea as the intention to do a criminal act).

23. Sayre, supra note 15 , at 412 (italics omitted). 
commit a crime . . . [an intent] to do that which, whether the defendant knew it or not, constitutes a breach of the criminal law."24

Sayre, frustrated by "the baffling problem of exactly what constitutes this necessary mens rea," 25 concluded that "it is quite futile to seek to discover the meaning of mens rea by any common principle of universal application running alike through all the cases." 26 "A mens rea does not mean a single precise state of mind which must be proved as a prerequisite for all criminality. Mens rea, chameleonlike, takes on different colors in different surroundings."27 While the old notion of "wickedness" may well have been satisfied by an identical showing for different offenses, the new notion of a specific state of mind could require a different state of mind for each crime or each general group of crimes. "The truth is," Sayre argued, "there is no single precise state of mind common to all crime. . . . The old conception of mens rea must be discarded, and in its place must be substituted the new conception of mentes reae."28

The Model Penal Code's move towards "element analysis" continued this refinement process by adding to the specific mental state concept detailed definitions of the required culpable states of mind. ${ }^{29}$ In addition, the concept of a different mens rea for each offense acquired a larger, more precise meaning. Under the Code, a culpable state of mind requirement may exist for "each material element" of an offense. ${ }^{30}$ Further, the culpability requirement may be different for different elements of the same offense. ${ }^{31}$

24. Id. see, e.g., G. WILliaMs, supra note $7, \S 14$, at 31 n.3; 2 J.F. STEPHEN, supra note 22, at 94-95; $f f . \mathrm{J}$. HALL, supra note 20, at 71, 103 (concluding that the term "mens rea" refers to actual distinctive states of mind as they relate to the actual prohibited harm and that different crimes involve different specific criminal intents).

25. Sayre, supra note 15 , at 411 (italics omitted).

26. Id. at 404 (italics omitted); see Sayre, Mens Rea, 45 HARv. L. Rev. 974, 1021 (1932).

27. Sayre, supra note 15 , at 402 (italics omitted).

28. Id. at 404 (italics omitted) (emphasis added). As another writer explains, "[e]ach crime . . has its distinctive mens rea, e.g., intending to have forced intercourse, intending to break and enter a dwelling-house and to commit a crime there, intending to inflict a battery, and so on. It is evident that there must be as many mentes reae as there are crimes." $\mathrm{J}$. HAlL, supra note 20 , at 142 .

29. See notes 52-82 infra and accompanying text.

30. Model Penal Code $\S 2.02$ (1) (Proposed Official Draft 1962) (emphasis added); accord, e.g., N.J. Stat. ANN. \& 2C:2-2(a) (West 1982); N.Y. Penal Law $\$ 15.10$ (McKinney 1975); 18 Pa. Cons. Stat. ANN. § 302(a) (Purdon 1973).

31. See, e.g., Model Penal CODE $\$ 220.2(3)$ (a) (1980) (a person who knowingly or recklessly fails to take reasonable measures to prevent a catastrophe commits a misdemeanor if he knows he has a duty to take such measures); see also Wechsler, Codification of Criminal Law in the United Siates: The Model Penal Code, 68 Colum. L. Rev. 1425, 1436-37 (1968) ("the required mode of culpability may not only vary from crime to crime but also from one to another 
"Offense analysis"- under which each offense has one state of mind requirement-existed and continues to exist as the dominant view of mens rea. Rather than requiring culpability as to "each material element," for example, several codes require an "act or intent, or criminal negligence" for "every crime or public offense." 32 Courts and statutes continue to speak of "general intent offenses" and "specific intent offenses." 33 Even the modern codes contain references to "an offense for which [a specified level of culpability] suffices to establish culpability," as if only one culpability level applied to each offense. $^{34}$

element of the same offense"). Indeed, the culpability terms are defined with respect to the objective elements of the offense. See MODEL PENAL CODE $\$ 2.02(2)$ (Proposed Official Draft 1962). For a discussion of the culpability terms, see notes 52-82 infra and accompanying text.

32. See Cal. Penal Code $\S 20$ (West 1970) (emphasis added); if. Kan. Stat. AnN. $\$ 21-3201$ (1) (1974) ("[C]riminal intent is an essential element of every crime . . . [and] may be established by proof that the conduct . . . was willful or wanton."); LA. REV. STAT. ANN. $\$ 14: 11$ (West 1974) ("definitions of some crimes require a specific criminal intent," others "consist merely of criminal negligence"). Similarly, other statutes define culpability terms that are applicable when "criminal intent is an element of a crime." See MINN. STAT. ANN. §609.02 (Subd. 9)(1) (West 1964); accord WIS. STAT. ANN. § 939.23(1) (West 1982). The implication is that the "criminal intent" is applicable on an offense-by-offense rather than an element-by-element basis. Indiana's new culpability provisions define the culpability terms only with respect to conduct and refer to the "kind of culpability . . . required for commission of an offense." IND. CODE ANN. § 35-41-2-2(a) (West 1978); see id. §35-41-2-2(b)-(d).

33. See, e.g., Colo. REv. STAT. \$ 18-1-501(5) (1978) (all offenses requiring intentional culpability are "specific intent offenses"); LA. REV. STAT. ANN. § 14:10 (West 1974) ("criminal intent may be specific or general"). Several jurisdictions classify crimes as specific or general intent offenses for the purpose of determining whether to admit evidence of mental disease or defect to negate the requisite mental state. In these jurisdictions, such evidence generally is admissible to negate a specific intent but not a general intent. See, e.g., People v. Wetmore, 22 Cal. 2d 318, 583 P.2d 1308, 149 Cal. Rptr. 265 (1978); Bimbow v. State, 161 Ind. App. 338, 315 N.E.2d 738 (1974); State v. Jacoby, 260 N.W.2d 828 (Iowa 1977); State v. Dargatz, 228 Kan. 322, 614 P.2d 430 (1980); Colo. REv. STAT. \$18-1-803 (1978); see also CAL. PENAL CODE $\S 28$ (a) (West Supp. 1983) (evidence of mental disease or defect admissible on the issue of whether the defendant actually formed specific intent or premeditated or deliberated where a specific intent offense is charged). Similarly, the distinction is determinative of the admissibility of intoxication evidence in several jurisdictions. See, eg., Ashbaugh v. State, -- Ind. -, 400 N.E.2d 767 (1980); Teves v. State, 33 Md. App. 195, 364 A.2d 593 (Md. C. Spec. App. 1976); State v. Lindahl, 309 N.W.2d 763 (Minn. 1981); State v. Kjeldahl, 278 N.W.2d 58 (Minn. 1979); Miller v. State, 567 P.2d 105 (Okla. Crim. App. 1977); State v. Reposa, 99 R.I. 147, 206 A.2d 213 (1965).

34. MOdel Penal Code $\S \S 3.02(2), 3.09(2)$ (Proposed Official Draft 1962) (lesser evils defense and other justification defenses unavailable where actor was reckless or negligent, and recklessness or negligence suffices to establish culpability for the offense charged); accora, e.g., ME. Rev. Stat. ANN. tit. 17-A, $\$ \S 101(3), 103(2)$ (1983); see also ME. Rev. Stat. AnN. tit. 17-A, § 103-A(3)(c) (1983); MODEL Pen.AL CODE $\$ 2.09$ (2) (Proposed Official Draft 1962) (duress defense unavailable where actor negligently placed himself in the situation giving rise to coercion and "negligence suffices to establish culpability"). For a discussion of these Model Penal Code provisions, see notes 170-82 infra and accompanying text. Another example of offense analysis is found in provisions that mandate that a specified culpability term be ap- 
The offense analysis approach continues even though it is not clearly viable even within its own terms. Unlike the "wickedness" notion, which could be applied generally, the specific state of mind requirement necessarily involves recognition of the multifaceted nature of the mental state for each offense. ${ }^{35}$ Under offense analysis, burglary requires an intention to commit a felony within a dwelling at night. ${ }^{36}$ Yet this "intention" requirement has several distinguishable parts: the intent to enter, the intent to do so at night, the intent that the building be a dwelling, and the intent to commit a felony within. Just as a broken clock is correct twice a day, offense analysis can accurately describe the culpability elements of an offense only if the same level of culpability (e.g., intention) is fortuitously the appropriate one for each element of an offense. But where different culpability levels are appropriate for different elements, offense analysis fosters definitions that obscure but do not eliminate the confusion. ${ }^{37}$

For many offenses, one particular element may be of central concern. Some murder statutes require that an actor intend to kill another human being, and some manslaughter statutes require that an actor be reckless as to causing the death of another human being. ${ }^{38}$ Thus, murder is commonly described as an "intentional" or "know-

plied to all offense elements, unless a contrary legislative purpose is evident. See, e.g., N.J. Stat. AnN. § 2C:2-2(c)(1) (West 1982); Model. Penal Code § 2.02(4) (Proposed Official Draft 1962); see also notes 161-82 infra and accompanying text.

35. See, e.g., Regina v. Faulkner, 11 Ir. R.-C.L. 8, 12 (Cr. Cas. Res. 1877) (rejecting proposition that a person who, while attempting to conceal a crime, accidentally causes harm is automatically culpable as to causing that harm and requiring either intention to cause or reckless disregard for causing the specific harm). For a discussion of the wickedness standard, see note 20 supra and accompanying text.

36. See Sayre, supra note 26 , at 1001 (the "present hard and fast technical requisite of an intent to commit a felony within the house invaded" developed during the judicial process that led to the distinction between felony and tort).

37. In Regina v. Prince, 2 L.R.-Cr. Cas. Res. 154 (1875), the confusion created by the offense analysis approach is evident. In dicta, Bramwell reasoned that: "[I]n the case of burglary, could a person charged claim an acquittal on the ground that he believed it was past six [a.m.] when he entered, or in a housebreaking, that he did not know the place broken into was a house?" Id. at 176 . Bramwell's reasoning evinces a common judicial solution to the problem presented when a stated culpability term seems to be improper for each element of the offense-imposition of strict liability as to all elements other than the one to which the stated term immediately applies. See note 51 infra. In addition, offense analysis often obscured the imposition of such strict liability since the culpability requirement that was present was enough to classify the offense as one requiring mens rea. Regina v. Prince, 2 L.R.-Cr. Cas. Res. at 173-76. For a discussion of the distortion inherent in another common judicial solution, that of applying the single specified culpability term to each offense element, see notes 161-82 infra and accompanying text.

38. See, e.g., MOdel Penal Code $\$ \S 210.1(1), 210.2(1)(a), 210.3(1)(a)$ (1980) (defining criminal homicide, murder, and manslaughter respectively). 
ing" offense, and manslaughter as a "reckless" offense. But even with murder, where a single culpability-culpability as to causing death-is of central concern, other culpability issues exist. An independent culpability element of homicide concerns the deceased's status as a "human being." A homicide case may hinge, for example, upon a doctor's state of mind as to whether an aborted fetus had matured into a "human being." 39 While intention may be the proper mental state to require for the objective element of "causing death," it may not be the appropriate mental state to require for the objective element of status as a "human being."

Because such questions can arise, they must be dealt with under any culpability scheme. Under offense analysis, these issues are frequently resolved by reference to a body of law that is conceived as separate from the definition of the offense, such as the law of mistake

39. For example, the Pennsylvania Abortion Control Act, 35 PA. Cons. Stat. AnN. $\S 6605$ (Purdon 1977), which was declared void for vagueness in Colautti v. Franklin, 439 U.S. 379 (1979), required the physician to determine, prior to performing an abortion, whether a fetus was or might be viable. Id. at $380 \mathrm{n} .1$. The statute subjected a physician who failed to do so to "such . . . criminal liability as would pertain to him had the fetus been a child who was intended to be born and not aborted." Id. at 381 n.1. Thus, the Supreme Court construed the term "human being" in the Pennsylvania homicide statute to include a viable fetus. Id. at 394; of. State v. Amaro, - R.I. —, 448 A.2d 1257 (1982) (fetus is not a "person" for purposes of Rhode Island's vehicular homicide statute).

In Pennsylvania, criminal homicide is defined as "intentionally, knowingly, recklessly or negligently caus[ing] the death of another human being." 18 PA. Cons. STAT. ANN. § 2501 (Purdon 1973). General code provisions require culpability as to each material element of a serious code offense. See id. $\S \S 302(a), 305$. Thus, if a physician performing an abortion were charged with homicide, the general culpability provisions of the Pennsylvania code would require culpability not only as to causing the death but also at least recklessness as to the fetus' viability. See id. $\$ 302$ (c)-(d). For a discussion of the ambiguity created by a similar tension between Model Penal Code $\$ \S 2.02(3)$-(4), see notes 170-82 infra and accompanying text. In Colauti, however, the Supreme Court ignored Pennsylvania's general provisions requiring culpability as to each offense element and concluded that while culpability was required as to causing the fetus' death under Pennsylvania law, culpability was not required as to the fetus' status as a "human being," based upon its viability. Colautti, 439 U.S. at 394-95. The Colautti decision illustrates the significance of culpability as to each element of an offense and the importance of clearly articulating the requisite culpability as to each element.

The murderer's guilt in a variety of cases may turn on the recognition that homicide requires culpability not only as to the element of "causing death" but also as to the element "of a human being." For example, if a hunter aims and fires at a creature moving behind cover, he, no doubt, intends to cause death. If, in fact, he kills a fellow hunter, his culpability depends on his awareness of the creature's status as a human being.

Separate culpability as to the victim's status is evident in the Indiana feticide offense, which provides that: "A person who knowingly or intentionally terminates a human pregnancy with an intention other than to . . remove a dead fetus commits feticide . . . " IND. CODE ANN. § 35-42-1-6 (West Supp. 1982-1983) (emphasis added); cf. GA. CODE ANN. § 26-1105 (Supp. 1982) (a person commits feticide if he "willfully kills an unborn child so far developed as to be ordinarily called 'quick' "). 
or accident. ${ }^{40}$ In other instances, such issues are deemed questions of first impression that, in the absence of controlling legislative history, courts feel free to decide on the basis of public policy arguments. ${ }^{41}$ Too frequently, counsel, who view the case from the perspective of offense analysis, simply fail to raise such issues. Element analysis does not create these kinds of issues, but simply acknowledges their existence and dramatically serves to expose and interrelate the variety of issues that are necessarily inherent in the definition of an offense.

\section{Element Analysis in Modern Codes: The Model Penal CODE GulPability SCHEME}

Section 2.02 of the Model Penal Code, which provides general rules for the definition of liability, is perhaps "the single most important provision of the Code"42 and the most significant and enduring achievement of the Code's authors. ${ }^{43}$ Since this portion of the Model Penal Code was drafted in $1955,{ }^{44}$ it has exerted a major influence on criminal law reform in all but two of the thirty-eight jurisdictions

40. For a discussion of the interrelationship between mistake and accident defenses and the culpability requirements of the offense definition under offense analysis, see note 210 infra and accompanying text.

41. In Regina v. Prince, 2 L.R.-Cr. Cas. Res. 154, 173-76 (1875), for example, the court apparently relied on the policy against taking a young woman from her father's care and concluded that the legislature intended to impose punishment regardless of the defendant's culpability as to the victim's age

42. Packer, The Model Penal Code and Beyond, 63 Colum. L. REv. 594, 601 (1963). Before the appearance of the Model Penal Code, Justice Jackson described the mental element in crime as "requisite but elusive," see Morissette v. United States, 342 U.S. 246,252 (1952), and many scholars had pointed to the need for reform. See generally Perkins, A Rationale of Mens Rea, 52 HaRv. L. REv. 905 (1939); Remington \& Helstad, supra note 16. Where the reform movement lags, the plea for and attempt at clarification continues. See Stuart, The Need to Codify Clear, Realistic and Honest Measures of Mens Rea and Negligence, 15 CRIM. L.Q. 160 (1973). The Model Penal Code drafters suggest that one of their goals is to bring rationality to the resolution of mens rea issues. MODEL Penal CODE $\$ 2.02$ comment 6 , at 124 (Tent. Draft No. 4, 1955). This objective is evident in the structural composition of the Code. See notes 43-94 infra and accompanying text

43. See Robinson, A Brief History of Distinctions in Criminal Culpability, 31 HastinGs L.J. 815, 815-21 (1980) (describing the advances made by the drafters of the Model Penal Code and outlining the distinctions among the Code's culpability terms). The praise for refined culpability schemes, however, is not universal. See P. BRETT, AN INQUIRY INTO Criminal GuILT 70-85 (1963) (arguing that culpability should be a simple judgment of moral blameworthiness made by a jury, not the result of codification efforts); Binavince, The Structure and Theory of the German Penal Code, 24 AM. J. CoMP. L. 594, 600 (1976) (complimenting the drafters of the German Penal Code for abandoning the effort to define culpability terms because such definition curtails the dynamic quality of the law).

44. The culpability provision, \$2.02, was presented to the American Law Institute in 1955. Model Penal. Code $\$ 2.02$ note on status of section (Proposed Official Draft 1962). 
where reform has occurred. ${ }^{45}$ Section 2.02 may appropriately be considered the representative modern American culpability scheme. $^{46}$

Section 2.02 has had a significant impact because it clarifies mens rea analysis. ${ }^{47}$ The eighty or so culpability terms existing in prior criminal $\operatorname{codes}^{48}$ narrow in the Code to four: purpose, knowledge,

45. Only 16 American jurisdictions have failed to enact penal codes reflecting the influence of the Model Penal Code culpability refinements. See Cal. Penal Code (West 1970 \& Supp. 1983); D.C. Code ANN. tit. 22 (1981 \& Supp. 1982); FLA. STAT. ANN. $\$ \S 775.01-895.08$ (West 1976 \& Supp. 1983); GA. CODE ANN. tit. 16 (1982); MD. ANN. Code art. 27 (1982 \& Supp. 1982); MASs. Gen. LAws ANN. chs. 263-274 (West 1980 \& Supp. 1983); Мich. СомP. LAWS ANN. §§ 750.1 to 759.END (West. 1968, Supp. 1983-1984 \& Supp. Pamph. 1983-1984); Miss. Code ANN. tit. 97 (1972 \& Supp. 1981); N.M. STAT. ANN. ch. 30 (1978 \& Supp. 1981); N.C. Gen. STAT ch 14 (1981 \& Supp. 1981); R.I. Gen. Laws tit. 11 (1981 \& Supp. 1982); S.C. Code ANN. tit. 16 (Law. Co-op. 1976 \& Supp. 1981); Tenn. Code ANN. tit. 39 (1982); VT. STat. ANN. tit. 13 (1974 \& Supp. 1982); VA. CoDE tit. 18.2 (1982 \& Supp. 1983); W. VA. Code ch. 61 (1977 \& Supp. 1983). But see Cal. Penal Code $\$ 188$ (West Supp. 1983) (defining malice). Only three of these jurisdictions have enacted codes since the advent of the Model Penal Codes: Florida, Georgia and Virginia. See 58 Appendix, 58 A.L.I. PROC. 517 (1981). For the status of criminal law reform in the remainder of these jurisdictions, see id. Some courts in these jurisdictions nonetheless seem to be influenced by the Model Penal Code definitions. See, e.g., People v. Woods, 416 Mich. 581, 331 N.W.2d 707 (1982) (holding that the term "malice" has taken on so many different meanings that it should not be employed in jury instructions and substituting instructions that require the jury to determine defendant's culpability as to causing death); see also notes 69,78 infra.

In two other jurisdictions the impact of the Model Penal Code culpability provisions is so minimal that they arguably should be included in the group showing no influence. Iowa and Nebraska define only "recklessly," and provide no rules of construction. IOWA CODE ANN. § 702.16 (West 1979 \& Supp. 1982-1983) (defining "recklessly"); Neb. REv. STAT. \& 28109(19) (1979 \& Supp. 1982) (defining "recklessly"). For jurisdictions codifying defined culpability terms, see note 49 infra. For jurisdictions adopting provisions similar to Model Penal Code $\$ 2.02$ (3) (Proposed Official Draft 1962), see note 84 infra.

46. Robinson, supra note 43 , at 816 .

47. Kadish, supra note 1 , at 1143 (crediting the drafters of the Montral mens rea issues in dispersing "the obscurantist cloud that hung for so long on the central mens rea issues in criminal law").

48. "The National Commission's [on Reform of the Federal Criminal Law] consultant identified 78 different terms used in present law." S. REP. No. 605, Part 1, 95th Cong. 1st Sess. 55 (1977); see Feinberg, Toward a New Approach to Proving Culpability: Mens Rea and the Proposed Federal Criminal Code, 18 AM. CRIM. L. REv. 123, 125 (1980). Examples of a confusing variety of culpability terms abound. See, e.g., N.J. STAT. ANN. § 2C:11-5 (West 1981) ("criminal homicide constitutes death by auto when it is caused by driving a vehicle carelessly and heedlessly, in a willful or wanton disregard" of the rights or safety of others) (emphasis added) (changed to recklessness standard by 1981 N.J. Sess. Law Serv. 312 (West); current version at N.J. STAT. ANN. § 2C:1 1-5 (West 1982)); see also MAss. GeN. LAWs ANN. ch. 266, $\S 100$ (West Supp. 1982-1983) ("willfully, intentionally and without right or wantonly and without cause, detains" a library book). Where reform lags or is incomplete, not only are a variety of terms used, but the terms are generally undefined and courts commonly supply inconsistent definitions. For example, under current federal case law "willful" has seven different definitions, and "knowingly" has five. See S. REP. No. 605, supra, at 55-56; Feinberg, supra, at 125-29. 
recklessness, and negligence. ${ }^{49}$ Each term is defined in relation to each objective element of an offense- i.e., conduct, attendant circumstance, or result. ${ }^{50}$ In addition, the drafters have developed general rules designed to eliminate confusion created when a legislature fails to specify a culpability requirement or to indicate whether a stated culpability term applies to one or to all of the objective ele-

49. The drafters explain: "[O]nly four concepts are needed to prescribe the minimal requirements and lay the basis for distinctions that may usefully be drawn." Wechsler, supra note 31, at 1436; see Model Penal Code $\S 2.02$ comment 2, at 124 (Tent. Draft No. 4, 1955). Drafters of state codes apparently agree. See, e.g., HAWAII REV. STAT. § 702-204 commentary (1976) ("It is safe to say that, for the purpose of the penal law, there are no subtleties of meaning in the language used in the prior law which cannot be achieved in a clear, lucid fashion by limiting the relevant states of mind to intent, knowledge, recklessness, and negligence'). With the exception of the jurisdictions listed at note 45 supra, American jurisdictions have attempted to reduce and define culpability terms. The jurisdictions listed below have adopted a limited number of defined culpability terms. Most have identified four terms and adopted the distinctions, if not the labels, proposed in MODEL Penal CoDE $\$ 2.02$ (Proposed Official Draft 1962). For a discussion of the distinctions, see notes 52-82 infra and accompanying text. The parentheticals below identify those jurisdictions that alter the Model Penal Code distinctions. Ala. CoDe $§ 13 A-2-2$ (1982); Alaska STat. $\$ 11-81.900(a)(1)$-(4) (Supp. 1982); ARIZ. Rev. Stat. ANN. § 13-203 (1978); ARK. STAT. ANN. § 41-203(1)-(4) (1977); Colo. Rev. Stat. § 18-1-501 (1978); ConN. Gen. Stat. AnN. § 53a-3(11)-(14) (West 1972); Del. CODE ANN. tit. 11, $\$ 231$ (1979 \& Supp. 1981) (Model Penal Code distinctions plus ordinary negligence); HAWAII ReV. STAT. § 702-206 (1976); IDAHO CODE § 18-101(1)-(5) (1979) ("wilfully," "neglect," "corruptly," "malice," and "knowingly"); Criminal Code of 1961, §§ 4-4 to -7, IlL. ANN. STAT. ch. 38, §§ 4-4 to -7 (Smith-Hurd 1972); IND. Code ANN. \$ 35-41-2-2(a)-(c) (West 1978) ("intentionally," "knowingly," and "recklessly"); KAN. STAT. ANN. §21-3201 (1981) ("willful" and "wanton"); KY. REV. STAT. §501.020(1)-(4) (1975) (using labels of "intentionally," "knowingly," "wantonly" (corresponds to recklessly), and "recklessly" (corresponds to negligently), but the distinctions are those of the Model Penal Code); LA. Rev. STAT. ANN. $\$ \S 14: 10-12$ (West 1974) ("specific intent," "general intent," and "criminal negligence"); ME. Rev. Stat. ANN. tit. 17-A, § 35 (1983); MinN. Stat. ANN. $\S 609.02$ (subd. 9) (West 1964) ("know" and "intentionally"); MO. ANN. STAT. $\$ 562.016$ (Vernon 1979); MONT. CODE ANN. § 45-2-101(33), (37), (58) (1981) (only three culpability distinctions; code labels what is usually classified as recklessness-conscious disregard of a risk-as "negligence" and does not impose criminal liability for what is usually considered "negligence"-culpable inadvertence); NEV. REV. STAT. \$ 193.010(12)-(14) (1973) ("knowingly," "maliciously," and "negligently"); N.H. REV. STAT. ANN. §626.2(II) (1974); N.J. Stat. ANN. § 2C:2-2(b) (West 1982); N.Y. Penal LAW § 15.05(1)-(4) (McKinney 1975); N.D. CENT. CODE $\S 12.1-02-02$ (1976) (also retaining "willfully"); OHIO REv. CODE ANN. $\S 2901.22(A)$-(D) (Page 1982); OR. Rev. Stat. § 161.085(6)-(10) (1981); 18 Pa. Cons. Stat. ANN. § 302(b) (Purdon 1973); S.D. Codirted Laws AnN. § 22-1-2(1)(a)-(e) (1979) ("malice," "intent," "knowledge," "recklessness," and "neglect"); TEX. PENAL CODE ANN. \$6.03 (Vernon 1974); UTAh Code ANN. $\S 76-2-103(1)-(4)$ (1978); Wash. Rev. Code AnN. $\S 9 A .08 .010$ (1) (1977) (in addition to the Model Penal Code distinctions, Washington retains "malice" and "willfullness"); id. $\$ \S 9 A .04 .110(12), 9 A .08 .010(4)$ ("willfulness" is defined as satisfied by "knowing"); WIS. STAT. ANN. $\$ 939.23$ (West 1982) ("intentionally" and "knowingly"); WYO. STAT. § 6-1-104(iii), (ix) (1983) ("recklessly" and "criminal negligence"); see also S. 1437, 95th Cong., 1st Sess. $\$ 302$ (1977).

50. See Model Penal Code $\$ 2.02$ (2) (Proposed Official Draft 1962); see notes 65-80 infra and accompanying text. 
ments of an offense..$^{51}$

\section{A. Culpability Terms Defined in Relation to Each Objective Element}

The Model Penal Code distinguishes between culpability terms as follows: A person acts "purposely" with respect to a result ${ }^{52}$ if his conscious objective is to cause such a result. ${ }^{53}$ A person acts "knowingly" with respect to a result if it is not his conscious objective, yet he is practically certain that his conduct will cause that result. ${ }^{54}$ The essence of the narrow distinction between these two culpability levels is the presence or absence of a positive desire to cause the result; purpose requires a culpability beyond the knowledge of a result's near certainty. In the broader sense, this distinction divides the vague notions of "maliciousness" or "viciousness" from "callousness." The former may simply be an aggressively ruthless form of the latter, which is perhaps the very quality that distinguishes the two levels of culpability. ${ }^{55}$

51. See Model Penal Code $\$ 2.02(3)$-(4) (Proposed Official Draft 1962). Prior to the Model Penal Code, the confusion of various undefined culpability terms was complicated by the necessity of determining whether the specified culpability elements applied to one or more of the objective elements. Indeed, this is the issue that brought Morissette v. United States, 342 U.S. 246 (1952), before the Supreme Court. While Morissette had knowingly taken shell casings from government property, he had believed that the property was abandoned. See id. at 248-49. Although the offense prohibited knowing conversion of government property, see id. at 248 , the trial court had imposed strict liability as to the circumstance element-government property-and required only that the taking be knowing. See id. at 249; see also State v. Hofford, 152 N.J. Super. 283, 377 A.2d 962 (Super. Ct. Law Div. 1977) (discussing similar issue raised by statute forbidding a "willful act of commission whereby unnecessary pain and suffering is caused to be inflicted on a child"). stances, at least where such definitions are meaningful. Chart I sets out the Code's definitions of culpable states of mind. See text accompanying notes 65-80 infra. Arguably, for example, to define recklessness or negligence with respect to conduct is not meaningful. Few jurisdictions do so. See note 152 infra; see also MOdel Penal CODE $\$ 2.02$ (2)(c)-(d) (Proposed Official Draft 1962) (apparently omitting these definitions). For a discussion of the omission, see notes 144-54 infra and accompanying text. The meaningfulness of a concept of acting intentionally with respect to circumstances has similarly been called into question. See S. REP. No. 95-605, Part 1, 95th Cong., Ist Sess. 58 n.13 (1977). Several jurisdictions do not define "purpose" with respect to circumstance elements. See note 66 infra.

53. Model Penal Cove $\$ 2.02(1)$ (a) (i) (Proposed Official Draft 1962).

54. Id \& 2.02(2)(b)(ii). Mo " 8 (d) as "aware of a high probability." Id. $\$ 2.02(7)$. This elabored See MODEL PENAL CODE $\$ 2.02$ only to the definition of "knowingly" as suffice to establish knowledge of an existing circumility but who chooses not to confirm his problem of the actor who is aware of a high probabiliticy "willul blindness").

belief-the British label this problem "willful blindness"). 
A person acts "knowingly" with respect to a result if he is nearly certain that his conduct will cause the result. If he is aware only of a substantial risk, he acts "recklessly" with respect to the result. ${ }^{56}$ The narrow distinction between knowledge and recklessness lies in the degree of risk - "highly probable" versus "substantial"- of which the actor is aware. ${ }^{57}$ The important distinction between recklessness (and lower levels of culpability) and both higher levels of culpability is that we condemn purposeful and knowing conduct for being "wilful," while we merely scold reckless conduct for being at most "careless." An offender whose conduct falls within the first category is often condemned for "intentional" conduct; one in the latter is scolded for "taking risks."

A person acts "recklessly" with respect to a result if he consciously disregards a substantial risk and acts only "negligently" if he is unaware of a substantial risk he should have perceived. ${ }^{58}$ The narrow distinction lies in the actor's awareness of risk. ${ }^{59}$ The distinction, one of the most critical to criminal law, between negligence and all three higher levels of culpability, reflects that a defendant acting purposely, knowingly, or recklessly is aware of the harmful consequences that may result and is therefore both blameworthy and deterrable, but a defendant acting negligently is unaware of harmful consequences and therefore is arguably neither blameworthy nor deterrable. While most reject this view of negligent culpability, ${ }^{60}$ all

poseful" and "knowing." See, e.g., G. Williams, supra note $7, \S 18$; Williams, The Mental Element in Crime, 27 REV. JUR. U.P.R. 193, 196-97 (1957-58).

56. MOdel Penal CODE $\$ 2.02(2)$ (c) (Proposed Official Draft 1962).

57. Compare id. $\S 2.02(2)$ (b) with id. $\S 2.02(2)$ (c). The Model Penal Code's drafters are careful to note that the determination of whether risk is "substantial" depends not only upon the particular likelihood of the result occurring, but also upon the situation at hand, including the countervailing interests. See MOdel Penal Code $\$ 2.02$ comment 3, at 125 (Tent. Draft No. 4, 1955). Indeed, they use the phrase "substantial and unjustifiable risk." MODEI Penal Code $\S 2.02(2)$ (c) (Proposed Official Draft 1962) (emphasis added).

58. Model Penal Code $\S 2.02(2)$ (d) (Proposed Official Draft 1962).

59. Compare id. $\S 2.02(2)$ (c) with id. $\S 2.02(2)$ (d). Note that "recklessness" is defined to mean awareness of the risk that the required result element will occur or that the required circumstance exists. "Recklessness" is not defined to require awareness of the risk that the defendant's conduct will break the law or subject him to criminal liability. See id. § 2.02(9); see also People v. Fullerton, 86 A.D.2d 70, 449 N.Y.S.2d 108 (App. Div. 1982) (awareness of the risk distinguishes recklessness and negligence).

60. The dispute over whether negligence or recklessness should mark the outer boundary of criminal liability is carried forward on several fronts. On the one hand, some argue that actual awareness or foresight of the consequences should be required because a person who by definition is unaware of the risk cannot be deterred from taking it. See J. HALL, supra note 20 , at 137 ; G. WILLIAMS, supra note $7, \S 43$, at $122-23$; $\$ 54$, at $150-52$. Further, negligent people arguably do not deserve punishment because their defect is not a moral one, but rather one of knowledge or understanding that particular conduct may cause a particular 
nonetheless recognize that negligence represents a lower level of culpability, qualitatively different from recklessness because the negligent actor fails to recognize, rather than consciously disregards, a risk. $^{61}$ For this reason, recklessness is considered the norm for criminal culpability, and negligence is punished only in the exceptional case. ${ }^{62}$

A person who fails to appreciate the risk that his conduct will cause a specific result is "negligent" only if that failure "involves a gross deviation from the standard of care that a reasonable person would observe in the actor's situation." 63 Thus, unless he grossly deviates from the standard of care that a reasonable person would observe, an actor is not negligent and, at least in the eyes of criminal law, is without cognizable fault. Liability imposed for faultless conduct is termed "absolute" or "strict" liability. The narrow distinction between negligence and strict liability focuses on whether the defendant's unawareness of the risk is a failure to meet the objective standard of the reasonable person. The broader distinction between the four categories of culpability and faultlessness is between conduct that grossly deviates from that of the reasonable, law-abiding person and conduct that does not and is therefore not blameworthy. Theoretical objections to strict liability understandably stem from a reluctance to punish conduct that is not unreasonable. ${ }^{64}$

Model Penal Code section 2.02(2) defines each culpability term with respect to each of the three kinds of objective elements: conduct, circumstance, and result. Chart I gives the section 2.02(2) definition for each variation.

harmful result. To punish such defendants is to punish them for being stupid. See Keedy, Criminal Law, 22 HARV. L. REV. 75, 84 (1908).

hand, many argue that just as the threat of punishment can cause people to

列 exercise greater control over their conduct, it can also cause thern to be $126-27$ (Tent. Draft
about potential harms. See MODEL. PENAL CODE $\$ 2.02$ comment 3, at 126 . REV. No. 4, 1955); Wechsler \& Michael, $A$ Rationale of the they 701, 751 (1937). Moreover, because inattention and thoughe frady, Runishment for Negligence: A Reply to Professor may be considered to be blameworthy. Seeller, On Common Law Mens Rea, 42 MiNN. L. REV. Hall, 22 BUFFaLO L. REV. 107 (1972), Metor is unaware in spite of an abil1043, 1063-64 (1958) (negligence is culpable because the 1962 SUP. CT. REV. 107, 144 (negligent ity to be so); Packer, Mens Rea and The Supreme Coun, 1960 drom acceptable standards of conduct).

actors are blameworthy because they deviate from acceptable standability share reliance on an

61. See Packer, supro note 60, at 144 ("negligence and sth

external standard that ignore

62. See note 87 infral Code $\$ 2.02(2)$ (c) (Proposed Official Draft 1962); see People v. Ful63. MODEL PENAL CODE $\$ 2.02(2)$ (c) (Proposed Official Draft 1962 ),
lerton, 86 A.D.2d 70, 449 N.Y.S.2d 108 (App. Div. 1982) (majority finds defendant's conduct
not a gross deviation under the circumstances; dissent disagrees).

64. For citations to relevant literature, see note 88 infra. 


\section{Chart I: Model Penal Code $§$ 2.02(2) Culpability DEFINITIONS}

A person acts [culpability level] with respect to [type of objective element] when:

\begin{tabular}{|c|c|c|c|}
\hline \multicolumn{4}{|c|}{ Type of Objective Element } \\
\hline & Circumstance & $\underline{\text { Result }}$ & Conduct \\
\hline Purposely $^{65}$ & $\begin{array}{l}\text { "he is aware of } \\
\text { such } \\
\text { circumstances } \\
\text { or hopes that } \\
\text { they exist" }\end{array}$ & $\begin{array}{l}\text { "it is his } \\
\text { conscious object } \\
\text { such a cause } \\
\text { suchult"67 }\end{array}$ & $\begin{array}{l}\text { "it is his } \\
\text { conscious object } \\
\text { to engage in } \\
\text { conduct of that } \\
\text { nature"68 }\end{array}$ \\
\hline$\underline{\text { Knowingly }}^{69}$ & $\begin{array}{l}\text { "he is aware } \\
\text { circumst that such } \\
\text { exist"70 }\end{array}$ & $\begin{array}{l}\text { "he is aware } \\
\text { that it is } \\
\text { practically } \\
\text { certain that his } \\
\text { conduct will } \\
\text { cause such a } \\
\text { result" }\end{array}$ & $\begin{array}{l}\text { "he is aware } \\
\text { that his } \\
\text { conduct is of } \\
\text { that nature" }\end{array}$ \\
\hline$\underline{\text { Recklessly }}^{73}$ & $\begin{array}{l}\text { "he consciously } \\
\text { disregards a } \\
\text { substantial and } \\
\text { unjustifiable } \\
\text { risk that the } \\
\text { material } \\
\text { element } \\
\text { exists""7 }\end{array}$ & $\begin{array}{l}\text { "he consciously } \\
\text { disregards a } \\
\text { substantial and } \\
\text { unjustifiable } \\
\text { risk that the } \\
\text { material } \\
\text { element . . } \\
\text { will result from } \\
\text { his conduct"75 }\end{array}$ & $-{ }^{76}$ \\
\hline Negligently $^{77}$ & $\begin{array}{l}\text { "he should be } \\
\text { aware of a } \\
\text { substantial and } \\
\text { unjustifiable } \\
\text { risk that the } \\
\text { material } \\
\text { element } \\
\text { exists"78 }\end{array}$ & $\begin{array}{l}\text { "he should be } \\
\text { aware of a } \\
\text { substantial and } \\
\text { unjustifiable } \\
\text { risk that the } \\
\text { material } \\
\text { element. . } \\
\text { will result from } \\
\text { his conduct"79 }\end{array}$ & $-^{80}$ \\
\hline
\end{tabular}

65. In addition to the definitions of "purpose" with respect to conduct, circumstance, and result, see text accompanying notes 66-68 infra, Model Penal Code $\$ 2.02(6)$ provides: "When a particular purpose is an element of an offense, the element is established although such purpose is conditional, unless the condition negatives the harm or evil sought to be prevented by the law defining the offense."

Several jurisdictions use the label "intentional" to refer to the Model Penal Code's "purposeful" culpability. See, e.g., Criminal Code of 1961, § 4-4, ILL. ANN. STAT. ch. 38, § 4-4 (Smith-Hurd 1972); N.Y. Penal Law \$ 15.05(1) (McKinney 1975); 18 PA. Cons. STat. AnN. $\S 302$ (b) (1) (Purdon 1973); see also S. 1437, 95th Cong., 1st Sess. $\$ 302$ (a) (1977). The drafters 
the terms. Model Penal Code $\$ 1.13(12)$ ("in-

of the Model Penal Code themselves equate the terms. Mode also People v. Frysig, - Colo. -, 628 P.2d tentionally or with intent means purposely" "intent" to "purpose" did not alter the intent 1004 (1981) (statutory change from inten requirement). Penal CoDe \$ 2.02(2)(a)(ii) (Proposed Official Draft 1962). Some jurisdic-

66. Model Penal Code \$ 2.02(2)(a)(ii) (Proposed Se, e.g., Colo. Rev. Stat. \$ 18-1tions do not define "purposeful" as to circumstance. See, STAT, ch. 38, $\$ 4-4$ (Smith-Hurd 503(1) (1978); Criminal Code of 1961, Vernon 1974); see also S. 1437, 95th Cong. 1st Sess. 1972); Tex. Penal Code AnN. \$ 6.03(a) (Nernon 1974); (1977).
$\$ 302(a)$ (i) (Proposed Official Draft 1962). Some jurisdic-

67. Model Penal Code $\$ 2.02(a)$ (i) (Proposed Official Draft 1962). Some jurisdictions define "specific intent" as a desire to produce the

68. MODEL PENAL CODE \$ 2.02(2)(a)(i) (Proposed Official Draft

. (8) provides that: A requect to the material elements of the willfully is satisfied if a person acts knowing wo further requirements appears." MODEL PeNAL CODE offense, unless a purpose to impose

$\$ 2.02(8)$ (Proposed Official Draft 1962) "knowingly" but they do not refer to each

California courts use a similar definition of kalban, 65 Cal. App. 3d 578, 135 Cal. Rptr. kind of element of an offense. See, e.g., People v. Calles (1976) ("knowingly" requires an awareness of the facts that bring the proscribed act within the terms of the statute).

70. MODEl Penal Code \$ 2.02(2)(b)(i) (Proposed Official Draft 1962). In addition, Model Penal Code $\$ 2.02(7)$ provides that: "When knowledge of the existence of a particular in element of an offense, such knowledge is established if a person is aware of a high probability of its existence, unless he actually believes that it does not exist." Id. $\$ 2.02(7)$.

71. Id. $\$ 2.02(2)$ (b) (ii)

72. Id. $\$ 2.02(2)$ (b)(i).

73. In addition, Model Penal Code $\$ 2.02(2)(\mathrm{c})$ provides the of the actor's conduct and the a nature and degree that, considering the nature and purposs deviation from the standard of circumstances known to him, its disregard inverve in the actor's situation." MODEL PENAL conduct that a law-abiding person would observe in

CoDe $\$ 2.02(2)$ (c) (Proposed Official Draft 1962).

74. Id.

75. Id.

76. Recklessness as to conduct is not defined. See id. For

this definition, see notes 144-54 infra and accompanying (d) provides that:

77. In addition, Model Penal Code $\$ 2.02(2)(d)$ prove foilure to perceive it

The risk must be of such a nature and degree that the and the circumstances known to considering the nature and purpose of his conduct and care that a reasonable person him, involves a gross deviation from the

would observe in the actor's situation.

MOdel Penal CODE \$ 2.02(2)(d) (Proposed

The Commentary acknowledges that the phrase in the actor's situactics, such as blindmuch flexibility. The Commentary notes that $\$ 2.02$ comment 3 , at 126 (Tent. Draft No. 4, ness, may be included. MODEL PENAL CODE $\$ 2.02$ co the phrase "considering the . . . cir1955). Even greater flexibility, however, is created by a subjective factor to an orherwise objective cumstances known to him." Both phrases adda determination. Other jurisdictions have codified purely Ala. Code § 13A-2-2(4) (1982); Alaska Stat. \$11.819 $18-1-501$ (1978); Conn. Gen. Stat. Stat. AnN. \$ 13-105(5)(d) (1978); Colo. REV. STAT. \$ 18-1-501(d)-(e) (1979 \& Supp. 1982) ANN. § 53a-3(14) (West 1972); DEL. Cone ArN. "' Kr. REv. STAT. \$ 501.020 (1975) (culpability la("criminal negligence" and "negligence"), KX" belled "reckless," but the substance of the deficis. \$193.010(14) (1981); N.H. REv. STAT. ANN. 
The Code's definition of each culpability term with respect to each kind of objective element of an offense reflects a fundamental and critical principle of the Code's culpability scheme: Different degrees of culpability may be required with respect to different elements of the same offense. For example, indecent exposure may be defined as follows:

A person commits a misdemeanor if, for the purpose of arousing or gratifying sexual desire . . . he exposes his genitals under circumstances in which he knows his conduct is likely to cause affront or alarm. ${ }^{81}$

Thus, knowledge is required as to some elements, while purpose is required as to others. ${ }^{82}$

\section{B. Culpability Requirements Stated in an Offense Definition}

As the offense definition quoted above illustrates, more than one mental state requirement for an offense may be stated explicitly in the offense definition. But while some level of culpability must be required for each element of an offense, ${ }^{83}$ offense definitions rarely include a culpability requirement for every objective element of the offense. The indecent exposure offense definition quoted above, for example, does not specify the culpability requirement that is applicable to the element of "exposes his genitals." Must the defendant be

$\$ 626.1$ (II)(d) (1974); N.D. Cent. CODE $\$ 12.1-02-02$ (d) (1976); Ohlo Rev. Code AnN. $\S 2901.22$ (D) (Page 1982); S.D. Codified Laws ANN. \$ 22-1-2(1)(e) (1979): TEX. PENAL CODE ANN. $\$ 6.03$ (d) (Vernon 1974) ("circumstances viewed from the actor's standpoint"); UTAH CODE ANN. $\$ 76-2-103(4)$ (1978) ("circumstances viewed from the actor's standpoint"); WASH. Rev. Code ANN. § 9A.08.010(d) (1977); S. 1437, 95th Cong., 1st Sess. § 302(d) (1977).

Several jurisdictions use the label "criminal negligence" to denote the Model Penal Code's "negligent" culpability. See, e.g., Ala. CODE § 13A-2-2(4) (1982); AlaskA STAT. $\S 11.81 .610$ (c) (Supp. 1982); Cal. Penal Code $\$ 20$ (West 1970); Colo. Rev. Stat. \& 18-1501 (3) (1978); Conn. Gen. Stat. AnN. §53a-3(14) (West 1972); Del. Code AnN. tit. 11, §231(c) (1979); LA. Rev. Stat. ANN. \$ 14-12 (West 1974); ME. Rev. STAt. ANN. tit. 17-A, $\S 35(4)$ (1983); Mo. ANN. STaT. § 562.016(5) (Vernon 1979); N.Y. Penal Law § 15.05(4) (McKinney 1975).

78. Model Penal Code $\$ 2.02(2)$ (d) (Proposed Official Draft 1962). Louisiana defines "general intent" in a similar fashion. See, e.g., State v. Elzie, 343 So. 2 d 712 (La. 1977) (a defendant will be held to have a "general intent" as to a result if the result would be reasonably expected to follow from the offender's voluntary act).

79. Model Penal Code $\S 2.02(2)$ (d) (Proposed Official Draft 1962).

80. Negligence is not defined with respect to conduct. Id.; see notes 144-54 infra and accompanying text.

81. Model Penal Code $\S 213.5$ (1980) (emphasis added)

82. The conceptual importance of recognizing that different culpability requirements may apply to different elements is discussed at notes 155-82 infra and accompanying text.

83. See Model Penal Code $\$ 2.02(1)$ (Proposed Official Draft 1962) ("a person is not guilty of an offense unless he acted purposely, knowingly, recklessly or negligently, as the law may require, with respect to each material element of the offense"). There are rare exceptions to this general rule. For Model Penal Code exceptions, see note 89 infra. 
purposeful, knowing, reckless, or only negligent as to exposing his genitals? General rules of construction supply the appropriate culpability requirement when the Model Penal Code offense definition leaves a gap as to an objective element.

\section{Culpability Requirements Supplied by General Provisions}

Model Penal Code section 2.02(3) supplies culpability requirements where offense definitions do not specify culpability for particular objective elements. Section 2.02(3) reads in "recklessly" for all circumstance and result elements. And, because of the Code's failure to define reckless conduct, it reads in "knowingly" for all conduct elements. ${ }^{84}$ An application of section 2.02(3) to the definition of the indecent exposure offense quoted above ${ }^{85}$ results in the following complete offense definition:

A person commits a misdemeanor if, for the purpose of arousing or gratifying sexual desire . . . he [knowingly engages in conduct by which he recklessly causes the exposure of what he is aware of a substantial risk (i.e., reckless) are] his genitals under circumstances in which he knows his conduct is likely to cause affront or alarm. ${ }^{86}$

84. Model Penal Code $\$ 2.02(1)$ demands proof of some culpability-purpose, knowledge, recklessness, or negligence- as to each objective element of an offense, see note 83 supra, but as illustrated in the text, such culpability requirements are rarely specified in the offense definition. Section 2.02(3) provides that: "When the culpability sufficient established if a person terial element of an offense is not prescribed by law, such element is estable CODE $§ 2.02(3)$ acts purposely, knowingly or recklessly with respect thereto. "MoDis "reckless" with respect to (Proposed Official Draft 1962). Thus a person "knowing" with respect to conduct elements. circumstance and result elements and at least knements and conduct elements The difference between circumstance and result elements an a discussion of the omission of cause "recklessly" is not defined with respect to conying text; text accompanying notes 144-54 this definition, see note 146 infra and accompanying text, text accockless with respect to the infra. Apparently the drafters believed that a person could nanying text.

nature of his conduct. See notes $145-46$ infra

The following states have codified provisions like $\$ 2$ in the definition of a crime. See lessness whenever a culpability requirement is not speco ANN tit. 11, § 251 (1979); HAWAI ARK. STAT. ANN. \$\$ 41-202(2), -204(2) (1977); Del. CODE ANN. 191, -104 (1981) (Montana's REV. STAT. $\S \S 702-204,-212$ (1976); MONT. CoDE Aally recklessness, see note 49 supra); $18 \mathrm{PA}$ definition of negligence is not negligence, but is act3ally Other jurisdictions codify a similar rule CONS. STAT. ANN. $\$ \S 302(\mathrm{c}), 305$ (a) (Purdon 1973 ). but allow the culpability requirement to be sa $\$ 501.010(1), .050$ (1975) (Kentucky's definitio not specify culpability. See KY. REV. STAT. $\$ 3501.010(1)$, OR. REV. STAT. \$\$ 161.105(1) of "recklessness" encompasses negligence, see id. clarity and ensure a minimum culpabilit $.115(2)$ (1981). These rules of

in every criminal offense.

85. See text accompanying note 81 supra.

86. MODel Penal CoDe $\$ 213.5$ (1980) (defining indecenty required is not prescribe CODE $\$ 2.02(3)$ (Proposed Official Draft 1962) (whely, knowingly, or recklessly).

an element is established if the person acts purposely, $\mathrm{kn}$ 
Obviously, such a comprehensive statement is rather contorted and difficult to understand. Moreover, the culpability requirements read in to complete the offense definition present significant issues less frequently than do the other elements. Precisely for. these reasons, a general provision such as Model Penal Code section 2.02(3) is most useful. It provides a comprehensive statement of all culpability requirements as well as a readable offense definition. Such general provisions can be used to provide the proper mental state requirements because recklessness is generally accepted as the theoretical norm. ${ }^{87}$

The absence of a specified culpability requirement does not mean that culpability is not required. Modern codes permit strict liablity in very limited instances, generally only for the least serious offenses, such as traffic violations. ${ }^{88}$ Model Penal Code sections 2.02(1) and 2.05 , and similar provisions in state codes, require culpability for all

87. The commentary to section 2.02(3) states that by imposing liability for recklessness, unless otherwise specified, the drafters establish "as the basic norm what usually is regarded as the common law position." MOdel Penal CoDe $\$ 2.02(3)$ comment 4, at 127 (Tent. Draft No. 4, 1955); see G. WilliaMs, supra note $7, \S 14$, at 31 (recklessness suffices to establish criminal liability in most cases). The punishment of reckless actors, in contrast to the punishment of negligent actors, supports both the deterrent and just punishment purposes of criminal law. See note 60 supra. That a reckless actor-one who consciously risks wrongdoing, see texts accompanying notes $58-62,74-76$ supra-can be deterred seems to be accepted without question. See J. HALL, supra note 20, at 135-41; W. LAFAVE \& A. SCOTT, supra note 7, § 30, at 216-17; Packer, supra note 60, at 143. The reckless actor "is conscious of a forbidden harm, he realizes that his conduct increases the risk of its occurrence, and he . . . decide[s] to create the risk. [Recklessness] is volitional in a wrong direction." J. HALL, supra note 20 , at 115.

The appropriateness of punishment for negligence is debatable. All agree that negligence should rarely be punished. See, e.g., MODEL PENAL CODE $\S 2.02$ comment 3, at 126-27 (Tent. Draft No. 4, 1955) (negligence should not generally be deemed sufficient in the definition of specific crimes); Williams, supra note 55, at 206 (punishing negligence should be limited to specific circumstances where the actor can be made to know that he ought to take special care). Others argue that negligence should never warrant the imposition of criminal sanctions. See note 60 supra.

Purposefulness is similarly infrequently required for the commission of an offense. See Model Penal. Code $\$ 2.02(2)$ (a) comment 3, at 125 (Tent. Draft No. 4, 1955) (noting that purposeful culpability is normally applicable only where prior law required specific intent or where it is desirable to distinguish between actors for sentencing purposes).

The norm of recklessness, however, does not always prevail. Where the offense definition does not specify a culpability for each objective element, but instead mentions only one culpability level, that level will frequently be applied to all elements unless a contrary purpose plainly appears. See MODEL PENAL Code $\S 2.02$ (4) (Proposed Official Draft 1962). The intended interaction of $\S 2.02(3)$ and $\S 2.02(4)$ is unclear. See notes 161-82 infra and accompanying text.

88. The scholarly comment opposing imposition of criminal sanctions for strict liability offenses is overwhelming. See, e.g., J. HALL, supra note 20, at 279-322; G. WILliams, supra note 7, §§ 75-90; Perkins, The Civil Offense, 100 U. PA. L. Rev. 832 (1952); Sayre, Public Welfare Offenses, 33 Colum. L. REv. 55 (1933); Sayre, supra note 26. 
elements of all offenses other than offenses classified as "violations." In some jurisdictions, when culpability is not required, a phrase such as "in fact" is inserted at the appropriate place in the offense definition to signal the absence of any culpability requirement. ${ }^{90}$

Legislatures can deviate in two ways from the Model Penal Code's norm of recklessness contained in section 2.02(3). First, as illustrated above, the legislature may modify a code offense definition by explicitly designating a culpability requirement other than recklessness for a particular objective element. Second, the legislature may provide that a single culpability requirement will apply to every element of an offense. ${ }^{91}$ This second alternative is provided by section 2.02(4), which codifies a general rule of statutory construction requiring that a stated culpability term be applied to all elements of the offense. ${ }^{92}$ Thus, where the offense of causing a suicide is defined to punish one who "purposely causes such suicide by force,"93 the actor must be purposeful as to the conduct, the effecting force, and the result of causing another to commit suicide. Normal rules of statutory construction would no doubt generate the same result. ${ }^{94}$

Model Penal Code sections 2.02(1), 2.02(2), and 2.02(3) commit the Code, and nearly all modern codes following its lead, to a system of element analysis.

89. See Model Penal Code $\S 2.05$ (Proposed Official Draft 1962). A violation cannot give rise to civil disability or legal disadvantage. Id. $\S 1.04(5)$. Where the offense is a violation, strict liability is imposed unless the offense states a culpability requirement or a court determines that application of a culpability requirement is consistent with effective enforcement of the law. If $\$ 2.05(1)(\mathrm{a})$. Where the offense is a non-Code offense, strict liability may be imposed where a legislative purpose to do so plainly appears. Id. $\S 2.05$ (1)(b). Where nonCode offenses are strict liability offenses, however, the offense must be punished as a violation unless a subsequent non-Code statute explicitly provides otherwise. Id. $\$ 2.05(2)(a)$.

90. ME. Rev. STAT. ANN. tit. 17-A, \& 34(4)(B) (1983); see also S. 1437, 95th Cong., 1st Sess. $§ 303(a)$ (2) (1978). Maine undercuts the clarity of this drafting device, however, by also allowing strict liability if a legislative intent to impose it otherwise appears. ME. REV. STAT. ANN. tit. 17-A, §34(5)(B). North Dakota adopts a device that is superior to Maine's. For strict liability to be imposed, the statute must state that "a person may be guilty without culpability." See N.D. CENT. CODE \& 12.1-02-02(2) (1976).

91. E.g., Model Penal Cone $\$ 212.2$ (1980) ("a person commits a felony ... if he knowingly holds another in a condition of involuntary servitude").

92. Section 202(4) provides that: "When the law defining an offense prescribes the kind of culpability that is sufficient for the commission of an offense, without distinguishing among the material elements thereof, such provision shall apply to all the material element: of an offense, unless a contrary purpose plainly appears." MODEL PENal CODE $§ 2.02(4$ (Proposed Official Draft 1962).

93. Model Penal Code $\S 210.5(1)$ (1980).

94. See Morissette v. United States, 342 U.S. 246, 263 (1952) (applying rule of stric construction to hold that knowledge element of a knowing conversion must apply to all objec tive elements of the offense). 


\section{The Case for Element Analysis}

Element analysis provides the comprehensiveness, clarity, and precision needed to give fair notice and to limit govermental discretion, as required by the legality principle. ${ }^{95}$ Taken together, the offense definition and the general culpability provisions can generate a comprehensive list of the minimum requirements for the offense. Such precise and clear offense definitions provide fair notice of the scope of the prohibition, ${ }^{96}$ eliminate the need for judicial construction that may expand or reduce that scope, ${ }^{97}$ and delineate the scope

95. The legality principle protects against punishment for activities not prohibited by law; it insures that the penal sanction will not be imposed without warning or arbitrarily. For a discussion of the legality principle and its demands, see notes 97-98 infra. See generally J. HALL, supra note 20, at 27-69. Historically, the principle has been most significant as a limitation on the power of the state. Id. at 27. The principle is applicable to all offense elements, both objective and mental. See, e.g., Colautti v. Franklin, 439 U.S. 379, 390 (1979) (objective element of abortion statute requiring viability determination is impermissibly vague and the statute is therefore void); Morissette v. United States, 342 U.S. 246, 263, 270-72 (1952) (employing the rule of strict construction, a corollary of the legality principle, see note 97 infra, as one basis for holding that the government must prove "knowledge" of each fact necessary to establish the prohibited conversion); Martin v. State, 261 Ark. 80, 547 S.W.2d 81 (1977) (the defendant challenged a battery statute on the ground that the offense definition did not specify the applicable mental state; the court upheld the statute on the ground that the general provisions of the code did identify the mental state).

96. A theory of just punishment relies upon the fact that the offender could have avoided the violation, and thus the punishment, by conforming his conduct to the requirements of the law. See A. von Hirsch, Doing Justice: The Choice of Punishments 45-55 (1976). Such conformity is not possible, of course, without notice of the requirements of the law. "The citizen must be able to ascertain beforehand how he stands with regard to the criminal law; otherwise to punish him for breach of that law is purposeless cruelty." $G$. WILLIAMS, supra note $7, \S 184$, at 575 .

In the United States, the fair notice aspect of the legality principle has been given constitutional significance under the void-for-vagueness doctrine. In Connally v. General Constr. Co., 269 U.S. 385 (1926), the Supreme Court held that: "[A] statute which either forbids or requires the doing of an act in terms so vague that men of common intelligence must necessarily guess at its meaning . . . violates the first essential of due process of law." Id. at 391. The Court has since explained the rationale: "The underlying principle is that no man shall be held criminally responsible for conduct which he could not reasonably understand to be proscribed." Palmer v. City of Euclid, 402 U.S. 544, 546 (1971) (per curiam) (quoting United States v. Harriss, 347 U.S. 612,617 (1954)). The principle thus requires legislatures to define offenses precisely. See, e.g., Colautti v. Franklin, 439 U.S. 379, 390 (1979).

97. As the legality principle requires prospective application of definite and predictable criminal laws, it necessarily limits judicial expansion of common law and statutory crimes. See J. Hall, supra note 20, at 31; W. LAFAVE \& A. ScotT, supra note 7, §9, at 67 . The force of the principle as a limitation on judicial authority is evident in: (1) the increased legislative role in the definition of criminal offenses, see J. HALL, supra note 20 , at 31 ; (2) the abolition of common law crimes, see note 102 infra; (3) the rule requiring strict construction of penal statutes, see, e.g., Morissette v. United States, 342 U.S. 246, 263 (1952); McBoyle v. United States, 283 U.S. 25, 27 (1931); and (4) the more recent rule that requires courts to adhere to the plain meaning of a penal statute, thus limiting the court's power to either significantly 
so as to limit the arbitrary administration and application of criminal laws. 98

Element analysis, by providing a precise statement of all separate elements of an offense definition, has the conceptual advantage of increased simplicity. It eliminates the need for separate bodies of law such as mistake and accident by demonstrating that these apparently independent doctrines are actually concerned with culpability as to particular objective elements. ${ }^{99}$ In addition, the clarity and precision of element analysis has the practical effect of reducing litigation by reducing ambiguities in offense definitions. Element analysis also has the practical advantage of reclaiming for the legislature the role of defining the requirements for criminal liability. Indeed, this may be its most important practical advantage. As noted previously, a variety of potential culpability issues exists in every offense, even though offense analysis may not consider them. When an offense analysis code definition fails to resolve a culpability issue, the courts must supply the answer. ${ }^{100}$ Thus, under offense analysis, a legislature in effect delegates to the courts certain authority to define crimes, a practice that is neither a wise ${ }^{101}$ nor a likely choice for a legislature of today. ${ }^{102}$

expand or restrict an offense definition. See, e.g., Cal. Penal Code $\$ 4$ (West 1970); DeL. Hawall Rev. STAT. \& 701-104 (1976); N.J. STAT. ANN. CODE ANN. tit. 11, § 203 (1979); HaWAII REV. STAT. $\$ 701-104(1976)$; 8 2C:1-2(c) (West 1982).

98. The legality principle and the vaguene Goguen, 415 U.S. 566, 575-76 (1974) (statuernment enforcement powers. See, e.g., Smith v. Goguen enforcement); Papachristou v. City of tory guidelines must be clear enough to anoid artate held void for vagueness because it enJacksonville, 405 U.S. 156 (1972) (vagrancy statictions); Grayned v. City of Rockford, 408 couraged arbitrary and erratic arrests and is to be avoided, laws must provide specific stanU.S. 104 (1972) (if arbitrary enforcemer Fair Freaks \& Attractions, Inc. v. Hodges, 267 So. 2d dards for those who apply them), World Faition of deformed persons or animals was unconsti817 (Fla. 1972) (statute prohibiting exhesonable standards for its application). See generally W. tutional because it failed to set forth reasonable stanc. THE LiMTrs OF THE Griminal. SANCLAFAVE \& A. SCOTT, supra note 7, \$11; H. PACKER, THE (1968)

99. See notes 210-30 infra and accompanying text.

100. See, e.g., Morissette v. United States, 342 U.S. 246 (19.5), State discussed at note 51 Super. 283, 377 A.2d 962 (Super. Ct. Law Div. 1978) (both cases are divan prospective definition o supra).

101. The practice requires case-by-case definition rather the its traditional limitation or

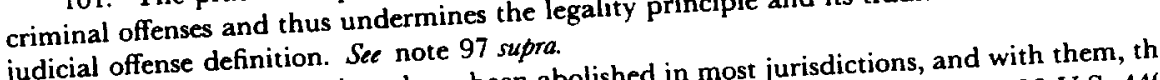
judicial offense definition. See have been abolished in most jurisdictions, and with them, th 102. Common law crimes have been abolished in mrulewitch v. United States, 336 U.S. 441 judiciary's authority to create offenses. (every federal prosecution must be sustained by stat 456-57 (1949) Uackson, J., concurring) (every $18-1-105(3)$ (1978); Del. CODE ANN. tit. 1 tory authority); accord COLO. REV. Se defined by statute); HAWAII REV. STAT. § 701-102( $\$ 202$ (a) (1979) (all offenses must be defan unless defined by code or another statute); $N$. (1976) (no act constitutes a crime or violatio 


\section{Confusion AND Ambiguities IN MODERN Culpability SCHEMES}

The Model Penal Code culpability scheme is a great improvement over "the variety, disparity, and confusion" of judicial definitions of "the requisite but elusive mental element" 103 that existed prior to its advent. As is nearly always the case with reform, however, even this great advance has its shortcomings. All jurisdictions that follow the Model Penal Code's formulation face a variety of common difficulties, ${ }^{104}$ and in some cases, states have made matters still worse by tinkering with the scheme's provisions without fully understanding the implications of their changes. ${ }^{105}$

\section{A. The Use of Undefined Culpability Terms}

Despite their adoption of a limited number of defined culpability terms, many jurisdictions have failed to restrict their drafting to the defined terms. For example, while purporting to adopt the Model Penal Code scheme of precisely defined culpability terms, New Jersey at one time used terms such as "carelessly,"106 "heedlessly,"107 "wanton,"108 "willful,"109 "intent,"110 and "criminal negligence""111 with-

STAT. ANN. § 2C:1-5(a) (West 1982) (no conduct constitutes an offense unless defined by code or another statute); see also State v. Pierre, 320 So. 2d 185 (La. 1975) (definition of crimes is a purely legislative function); note 97 supra (discusses statutes requiring a construction of code provisions in light of legislative intent).

103. Morissette v. United States, 342 U.S. 246, 252 (1952). For a brief discussion and for citations to more elaborate discussions of problems under prior law, see notes 42,48 supra.

104. For an identification and discussion of the state codes that follow particular provisions of the Model Penal Code scheme, see notes 95-102 supra and accompanying text; notes 105-82 infra and accompanying text. Only Pennsylvania has adopted verbatim every culpability provision of the Model Penal Code. See 18 PA. Cons. STAT. ANN. §§ 302, 305 (Purdon 1973).

105. See notes $157-60$ infra and accompanying text. Some jurisdictions have improved upon the Code's provisions: See notes 152-53 infra and accompanying text.

106. N.J. STAT. ANN. § 2C:11-5 (amended 1981). This error has been corrected recently. The New Jersey death-by-auto statute that employed the term "carelessly" has been amended to substitute the term "recklessly." Id. § 2C:11-5 (West 1982).

107. See, e.g., id. \$ 2C:11-5 (amended 1981). "Heedlessly" has also been replaced by "recklessly." Id. § 2C:11-5 (West 1982).

108. See, e.g., id. § 2C:11-5 (amended 1981). "Wanton" has also been replaced by "recklessly" in this statute. Id. $\S 2 \mathrm{C}: 11-5$ (West 1982).

109. See, e.g., id. § 2C:24-5 (West 1982) (defining willful nonsupport). While the Model Penal Code contains a provision establishing that the requirement of "willfully" is satisfied by "knowingly" unless a purpose to impose further requirements appears, see MODEL PENAL CODE $\S 2.02(8)$ (Proposed Official Draft 1962), New Jersey has failed to adopt the provision.

110. See, e.g., N.J. STAT. ANN. $\S 2$ C:21-6(b)-(c) (West 1982). Of course the use of the culpability term "intent" does not present a problem where a jurisdiction defines that term. See, e.g., note 65 supra (discusses statutes that use the term "intentional" to refer to the Model 
out defining them. ${ }^{12}$ Such undefined terms obviously undercut the Model Penal Code's advances in clarity, consistency, and predictability, characteristics particularly important in a criminal code.

\section{B. Difficulties in Determining Whether an Objective Element Is a Conduct, Circumstance, or Result Element}

A major defect of the Model Penal Code is its failure to define adequately the three kinds of objective elements of an offense-that is, to distinguish conduct, circumstance, and result elements. For example, is "obstructs"113 a conduct or a result element? Does "insults another in a manner likely to provoke violent response" ${ }^{114}$ consist of a single conduct element or of one conduct element and one or more

Penal Code's "purposeful" culpability). The problem is also eliminated where a jurisdiction equates "intent" and "purpose" in a general definition section. See, e.g., MODEL PENal CODE $\$ 1.13(12)$ (Proposed Official Draft 1962). Unfortunately, New Jersey has done neither, but it nonetheless employs the term.

111. See, e.g., N.J. Stat. ANN. \$2C:2-3(c) (West 1982). Some jurisdictions, unlike New Jersey, define "criminal negligence," see statutes cited at note 77 supra (using the term "criminal negligence" to refer to the Model Penal Code's "negligence" culpability), and thus avoid the problem.

112. Other examples are more subtle. For example, the drafters of the Model Penal Code codify an offense of nonsupport, which they define as "persistent" nonsupport. MODEL PENAl CODE $\$ 230.5$ (1980). "Persistent" implies a certain culpable state of mind, seeming to connote more than a repeated failure to provide support. The difficulty in determining which of the four defined culpable states of mind reflects the appropriate culpability may suggest that the culpability distinctions embodied in the four terms are insufficient. One could therefore argue that additional culpability terms are required. It seems more likely, however, that recklessness as to the circumstances "regular and timely payment" would suffice.

Similarly, verbs that seem to require "purposeful" action should be equated explicitly with "purpose" or avoided. They may be misinterpreted as requiring an undefined culpability. For example, criminal coercion may be defined to prohibit an act "calculated" to harm. See, e.g., N.J. STAT. ANN. \& 2C:13-5(a)(7) (West 1982). Such an act is arguably performed with the purpose of harming. The potential problem may be clarified, arguably, by a New Jersey general part provision which states that "designed" and "equivalent terms" have the same meaning as "purposely." Id. \$2C:2-2(b)(1). However, one may wonder why, for the sake of clarity, "designed" was not used in the criminal coercion statute. Similarly, one may ask why the phrase "negligent as to being observed" is rejected in favor of the undefined "reasonably expects is likely to be observed" in the lewdness statute. See id. § 2C:14-4. A similar problem emerges when adverbs like "surreptitiously" are employed. See id. § 2C:18-2 (defining burglary). Such terms hint at, but do not express, specific culpability requirements and will no doubt generate unnecessary litigation.

113. Model Penal Code $\S 250.7$ (1980). For a brief discussion of this provision, see note 129 infra and accompanying text. For a discussion of the problem created by verbs combining conduct and result, or conduct and circumstance elements, in a single term, see notes $128-43$ infra and accompanying text.

114. Model Penal Code $\$ 250.4$ (b) (1980). 
circumstance elements? Does "the death of another human being"115 consist of a single result element or of a result element and a circumstance element?

Precise definitions of these three categories are important because such categories are used as terms of art in many places in the Code. ${ }^{116}$ Perhaps even more important, a precise definition is essential for proper application of the defined culpability terms. For example, to act "purposely" with respect to "conduct" or in causing "a result," an actor must have such elements as his conscious object;117 but to act "purposely" with respect to "an attendant circumstance," an actor need only be aware of such circumstance or hope that it exists. ${ }^{18}$ Because of this asymmetry in the definitions of culpability as to different kinds of elements, the classification of an element becomes critical. The precise culpability requirements cannot be determined until each objective element of an offense definition is properly characterized as involving either "conduct," "an attendant circumstance," or "a result." The Code does not define "result" or "circumstance." It defines "conduct," but uses seemingly contradictory forms of that term in different Code provisions. Section 1.13 takes a narrow view, suggesting that "conduct" simply requires a bodily movement. ${ }^{119}$ Section 2.02 , in contrast, uses "conduct" in a broad sense to mean bodily movement and all its relevant characteristics. ${ }^{120}$

The practical problems created by the absence of a definition of the three types of objective elements-conduct, circumstance, and result - severely undercut the usefulness of defined culpability terms. For example, "theft by deception" entails purposely obtaining prop-

115. Id. $\S 210.1$.

116. See, e.g., Model Penal Code $\S 2.03$ (Proposed Official Draft 1962) (defining the necessary causal relationship between conduct and result elements; id. $\S 5.01(1)$ (b) (providing special culpability requirements as to a result element where attempt is charged); see also note 186 infra (discusses § 2.03); notes 299-303 infra and accompanying text (discusses $\S 5.01(1)(b))$.

117. See text accompanying notes $67-68$ supra.

118. See text accompanying note 66 supra.

119. See Model Penal Code $\S 1.13(2)$ (Proposed Official Draft 1962) (an act is a bodily movement); id. $\S 1.13(5)$ (conduct means an act or series of acts and its accompanying state of mind). For a proposal including a narrow definition of conduct, see notes 183-203 infra.

120. The Code defines the culpability terms not with respect to one's "conduct," but rather with respect to the "nature of" one's conduct. See MODEL PENAL CODE $\$ 2.02$ (2)(a)(i), (b) (i) (Proposed Official Draft 1962); texts accompanying notes 68, 72 supra. This "nature of" language suggests that the conduct element must incorporate more than a mere bodily movement. 
erty through deceit. ${ }^{121}$ A person "deceives" if he purposely "[c]reates or reinforces a false impression [as to value]."122 Assuming, arguendo, that the prohibited "conduct" is "creates" or "reinforces," the proscribed "result" may be interpreted as either (a) a false impression as to value (with no "attendant circumstance"), (b) a false impression (with value as a "circumstance"), or (c) an impression (with both falsity and value as "circumstances"). Or, one might argue that the definition contains only a single elaborate conduct requirement: "creates or reinforces a false impression as to value."

Assume that a court applies section $2.02(4)^{123}$ and requires that the defendant have acted purposely with respect to each element of this offense. The actor's conscious object must then encompass all conduct and results, ${ }^{124}$ but because of the way "purposeful" as to a circumstance is defined, the actor need only be aware of the existence of a circumstance element, or hope that the circumstance element exists. ${ }^{125}$ If the court applies interpretation (a) described above, the actor's conscious object must encompass every element of the offense because all elements are either conduct or results. ${ }^{126}$ If interpretation (b) is applied, however, the actor's conscious object must encompass only "creating" and a "false impression"; he need only be aware that the false impression that was purposely created concerns "value." Finally, if the court applies interpretation (c), the actor's conscious object need only encompass "creating an impression"; he need only be aware of the fact that the impression is "false" and concerns "value." These differences create the potential to manipulate improperly the defendant's liability by altering the content of the categories "conduct," "result," and "circumstance," thereby altering the applicable

121. Model Penal Code $\S 223.3$ (1980).

122. Id. § 223.3(1).

123. Model Penal Code $\$ 2.02(4)$ (Proposed Official Draft 1962). See also notes 161-69 infra and accompanying text (discusses $\S 2.02(4)$ ).

124. See text accompanying notes $67-68$ supra.

125. See text accompanying note 66 supra.

126. See text accompanying notes 67-68 supra. "Conscious object" will apply to the conduct "creates" and to the result "creates a false impression as to value." As the text indicates, however, this construction is not the only possible one, because the terms "conduct," "circumstance," and "result" are undefined. Whenever the definition of a culpability term varies with the kind of objective element to which it applies, there are, in effect, as many culpability terms as there are kinds of objective elements. For a discussion of an additional ambiguity created by a failure to define the objective elements, see Rothstein, Special ReportFederal Criminal Code Revision: Some Problems With Culpability Provisions, 15 CRIM. L. BULL. 157, 160 (1979) (arguing that the undefined phrase "nature of the conduct" might be construed so broadly as to encompass the "moral" nature of the conduct). 
culpability definition. ${ }^{127}$

\section{Combining Conduct and Result or Conduct and Circumstance Elements in a Single Term}

Difficulties in distinguishing conduct, circumstance, and result elements also arise because most modern codes, including the Model Penal Code, use terms that combine "conduct" and "result" or "conduct" and "circumstance" elements. Verbs like "damages,"128 "obstructs,"129 "destroys,"130 "falsifies,"'131 "kills,"132 and "desecrates"133 all combine both an act and a result of that act. Verbs like "compels," 134 "agrees,"135 and "removes"136 all combine both conduct and circumstance elements. Such combinations create ambiguities ${ }^{137}$ and undermine consistency in the operation of the Code. ${ }^{138}$

127. For some workable definitions for distinguishing "conduct," "circumstance," and "result" elements, see notes 183-203 infra and accompanying text.

128. MODEl PeNal CODE $\S 220.3$ (1980) (defining offense of criminal mischief).

129. Id. $\S 250.7$ (defining offense of obstruction of a highway). This verb seems to require a result: A prosecutor must establish that the road became impassable.

130. Id. $\$ 224.3$ (defining offense of destruction of recordable instruments).

131. Id. $\$ 224.4$ (defining offense of falsification of records)

132. Id. $\S 250.11$ (defining offense of cruelty to animals); $c f . i d . \$ 210.1$ (defining homicide as causing the death of, rather than killing, a human being).

133. Id. $\S 250.9$ (defining offense of desecration of venerated objects).

134. Id. $\$ 213.1(1)$ (a) (defining the offense of rape). The term "compels" implies an unstated yet required circumstance element: lack of consent.

135. Model Penal Code $\$ 5.03$ (1) (a) (Proposed Official Draft 1962) (defining conspiracy). The term "agrees" in the definition of conspiracy implies an unstated circumstance requirement of a meeting of the minds.

136. MODEl PENAL CODE $\S 212.1$ (1980) (defining kidnapping). The actor must "remove" his victim from the victim's residence or place of business. Like the term "compels," the term "removes" implies the absence of consent.

137. On the one hand, a court may divide these combined terms into separate conduct and result elements, as the Code does with other offenses (homicide, for example, is not defined as killing but rather as causing "the death of another human being," MODEL PENAL CODE $\S 210.1(2)(1980)$ ), and apply the appropriate culpability term. On the other hand, the court may treat the combined form as either a single broad conduct or a single broad result element and apply the culpability definition for either conduct or results. See notes 119-20 supra and accompanying text.

138. The drafters of the Model Penal Code admit that "the problem of the kind of culpability that is required for conviction must be faced separately with respect to each material element of the offense. . . " MODEL PENAL CODE $\$ 2.02$ comment 1, at 124 (Tent. Draft No. 4, 1955). Perhaps the drafters "faced the issue separately" with respect to conduct and result in defining the offenses discussed above and determined that, in cases where conduct and result are combined in one element, the same culpability term should apply to both elements. This approach undermines the precision of the culpability definitions, however, because in order to apply those definitions the court must segregate the conduct and result aspects of these verbs. Recall that with the exception of "purposeful," the definitions of culpability terms vary depending on whether the objective element is a conduct or a result ele- 
Consider a statute that forbids "recklessly obstructing any highway." What culpability should be required as to obstructing? A court might take any of three possible approaches. Because "recklessly" is not defined with respect to conduct, ${ }^{139}$ a court may determine that "knowing" is the appropriate culpability for obstructions, since it is the minimum culpability defined with respect to conduct. ${ }^{140}$ Second, a court may attempt to define reckless conduct, ${ }^{141}$ but given the enactment of a comprehensive culpability scheme, this seems clearly a legislative task. A third, and perhaps the best, approach may be for a court to observe that the verb "obstructing" is a combination of separate conduct and result elements. The term " 'obstructs' means to render impassable without unreasonable inconvenience or hazard." 142 In essence, the offense imposes liability when an actor engages in conduct by which he causes-i.e., "renders"any highway to be impassable. ${ }^{143}$ The culpability term "recklessly," under this approach, can be meaningfully read to apply to the result element of causing the highway to be impassable. The separate conduct element may be interpreted as requiring "knowing" conduct because that is the minimum culpability defined as to conduct.

\section{Failure to Define Recklessness and Negligence with Respect to Conduct}

As illustrated previously, the Model Penal Code's failure to define recklessness and negligence in relation to conduct creates certain difficulties. ${ }^{144}$ One explanation for this failure is that the drafters determined that neither recklessness nor negligence as to conduct is likely to arise. The Model Penal Code commentary notes that "[w]ith respect to each of [the] three types of elements, the draft attempts to

ment. See text accompanying notes 65-80 supra. The drafters' combination of result and conduct elements treats the two as if they were interchangeable, a practice that invites courts to do the same and to misapply the culpability terms.

139. See text accompanying note 76 supra. For a discussion of this omission, see notes 144-54 infra and accompanying text.

140. See texts accompanying notes $68,72,76,80$ supra.
141. For a jurisdiction defining "recklessness" as to conduct, see note 152 infra and accompanying text.

142. Model Penal Code § 250.7(1) (1980) (emphasis added).

143. This is the format frequently but not uniformly employed in the proposed Federal Criminal Code. Compare S. 1437, 95th Cong., 2d Sess. $\$ 1601$ (1978) ("homicide" defined as engaging in conduct by which one causes the death of another) with id. $\$ 1511$ ("obstructing" elections; conduct and result elements are combined).

144. See Model Penal Code $\$ 2.02(2)(c)-(d)$ (Proposed Official Draft 1962); see also texts accompanying notes 76,80 supra. For a discussion of the ambigness and negligence with respect to conduct, see note 146 infra. 
define each of the kinds of culpability that may arise."145 Other sections of the commentary, however, might be interpreted to suggest that the drafters did contemplate the possibility of recklessness or negligence as to conduct. ${ }^{146}$ Indeed, certain Code offenses appear specifically to cover reckless conduct. For example, one who "recklessly tampers with tangible property of another so as to endanger person or property" commits criminal mischief. ${ }^{147}$ Similarly, one who "purposely or recklessly. . . kills or injures any animal" is guilty of cruelty to animals. ${ }^{148}$

One resolution of this difficulty is to argue that since some culpability is required as to each element of the offense ${ }^{149}$ and since "recklessness" and "negligence" as to conduct are not defined, "knowledge" - the minimum culpability that is defined with respect to conduct-should be required. ${ }^{150}$ This argument can be buttressed

145. Model Penal Code $\S 2.02$ comment 2, at 124 (Tent. Draft No. 4, 1955) (emphasis added).

146. The commentary accompanying the definition of recklessness states that: "Whether the risk relates to the nature of the actor's conduct or to the existence of the requisite attendant circumstances or the result that may ensue is immaterial; the concept is the same." Id. at 125 (emphasis added). At least one author thinks the Model Penal Code definition may include recklessness as to conduct, but he does not give a rationale in support of his position. See Karlen, Mens Rea: A New Analysis, 9 U. Tol. L. ReV. 191, 199 n.25 (1978). But of. Williams, supra note 55, at 202 (suggesting that the Model Penal Code definition of recklessness applies only to circumstance and result elements). A comparison of the definitions of "purposely" and "knowingly" with the definitions of "recklessly" and "negligently" suggests that only the former terms are defined with respect to conduct. "Purposely" is defined using the phrases "nature of his conduct," "result thereof," and "attendant circumstances." MODEL Penal CODE $§ 2.02$ (2)(a)(i)-(ii) (Proposed Official Draft 1962). "Knowingly" is defined using the phrases "nature of his conduct or the attendant circumstances" and "result." "Recklessly" and "negligently," in contrast, are defined using the phrases "material element exists or will result from his conduct." Id. $\S 2.02(2)(\mathrm{c})-(\mathrm{d})$. In the definition of "knowingly" and "purposely," the term "exists" is used to refer only to attendant circumstances. Normal rules of construction would give it the same meaning in the parallel subsection defining "recklessly" and "negligently." The absence of a phrase like "conduct of that nature" or "conduct is of that nature" would most likely be construed to be an intentional omission when these four definitions are compared. Some may argue that the phrase "material element exists" applies to conduct. Beyond the inconsistency in the use of this phrase, the result is illogical on its face. Can one "disregard[ ] a substantial and unjustifiable risk that [one's conduct] exists"? See id. $\$ 2.02(2)$ (c). Perhaps because the definitions of "recklessly" and "negligently" do not appear to apply to conduct, several jurisdictions have explicitly statcd that recklessness and negligence do not apply to conduct. See note 153 infra and accompanying text. Others have redefined these culpability terms to supply the omitted definitions. See note 152 infra
and accompanying text.

147. E.g., Model Penal Code $\S 220.3(1)$ (b) (1980).

148. E.g., id. § 250.11

149. Model Penal Code $\S 2.02$ (1) (Proposed Official Draft 1962). See note 84 supra; text accompanying notes $88-90$ supra.

150. See note 84 supra and accompanying text. 
by referring to section $2.02(5)$, which states that: "When recklessness suffices to establish an element, such element also is established if a person acts purposely or knowingly." 151 Another solution is to define expressly "recklessness" and "negligence" with respect to conduct, ${ }^{152}$ or, alternatively, to provide clearly that recklessness and negligence do not apply to a conduct element and that knowledge is the minimum culpability as to conduct. ${ }^{153}$ Perhaps the best approach is to define "conduct" narrowly so as to limit the significance of the culpability as to that element to involuntary acts and to consider all issues raised by the nature of one's conduct as circumstance elements, for which "recklessness" and "negligence" are defined. ${ }^{154}$

\section{E. Variations on Model Penal Code Section 2.02(3) (Requiring Recklessness Where Culpability Is Not Specified)}

Model Penal Code section 2.02(3) requires recklessness for any element for which the offense definition does not specify culpability. As noted previously, this critical provision assures readable yet comprehensive offense definitions. ${ }^{155}$ Some jurisdictions clarify the drafting problems that complicate the application of section $2.02(3) .{ }^{156}$ Unfortunately, some jurisdictions deviate from the Code's approach by failing to include any provision like section $2.02(3) .{ }^{157}$ This creates greater ambiguity, especially because these jurisdictions commonly include a code provision that requires culpability as to each

151. Model Penal Code $\$ 2.02(5)$ (Proposed Official Draft 1962).

152. See, e.g., Hawail Rev. STAT. $\S 702-206(3)$ (b) (1976) (defining "recklessness" as to conduct); IND. CODE ANN. \$ 35.41-2-2(c) (West 1978) (same).

153. See, e.g., Al.ASKA STAT. $\$ \$ 11.81 .610(\mathrm{~b}), .900(\mathrm{a})(2)$-(4) (Supp. 1982); see also S. 1437, 95th Cong., 2d Sess. $\$ \S 302$ (c), 303(b)(1) (1978) (recklessness as to conduct undefined; minimum state of mind that must be proved with respect to conduct is knowledge). The following jurisdictions also clearly exclude conduct from their definitions of recklessness and negligence, but they do not provide specifically that knowledge is required where no culpability as to conduct is specified in the offense definition. ARIz. REV. STAT. ANN. § 13105(5)(c)-(d) (1978); Colo. Rev. Stat. § 18-1-501(3), (8) (1978); Ky. Rev. STAT. $\S 501.020(3)$-(4) (1975); Mo. AnN. STat. § 562.016(4)-(5) (Vernon 1979); Ohio Rev. Code ANN. \$ 2901.22(c)-(d) (Page 1982); Or. Rev. Stat. \$ 161.085(9)-(10) (1981); TeX. Penal CODE ANN. §6.03(c)-(d) (Vernon 1974); UTAH CODE ANN. § 76-2-103(3)-(4) (1978).

154. See notes $183-200$ infra and accompanying text.

155. See text accompanying notes 84-87 supra.

156. See, e.g., note 153 supra (discusses statutes that eliminate confusion in the application of $\S 2.02(3))$.

157. In fact, only a few jurisdictions adopt a provision that is equivalent to the Code'si.e., one that prohibits the imposition of criminal sanctions without culpability for all but minor violations and at the same time requires at least recklessness where culpability is required but not specified. See note 84 supra. 
objective element. ${ }^{158}$ In the absence of a general section to supply unstated culpability requirements, it is left to the court to select the applicable culpability requirement. ${ }^{159}$ This delegation to the courts undercuts predictability and permits inconsistency between similar cases-just the sort of ambiguity and confusion that spurred the development of modern culpability schemes. Further, absent a provision like section 2.02(3) that reads in "recklessly" or "knowingly" for an unstated culpability term, judges may consider the general requirement of some culpability to be satisfied by negligence; this vitiates the commonly stated preference against criminal liability for negligence. ${ }^{160}$

158. Several jurisdictions do not have a general gap-filling provision that specifies the culpability that should be required when the offense definition does not provide one, but have nonetheless adopted provisions that require some culpability always to be present, at least in offenses of a certain severity. See CAL. PENAL CODE $\$ 20$ (West 1970) (every crime must have union of act and intent, or criminal negligence); KAN. STAT. ANN. \$ 21 -3204 (1981) (absolute liability for misdemeanors only); LA. REV. STAT. ANN. $\$ 14.11$ (West 1974) (crime requires either specific intent, general intent, or criminal negligence); NEV. REV. STAT. \$ 193.190 (1981) (every crime requires a union of act and guilty mind). Many state codes, however, merely create a presumption that culpability is required where none is specified. The presumption is strong where the penalty is severe. Some of these states direct the court to require at least recklessness if the presumption is not defeated by a contrary indication of legislative intent and thus avoid ambiguity. More frequently, the court is permitted to apply any of the defined culpability requirements. See Criminal Code of $1961, \$ \$ 4-3,-9$, ILL. ANN. STAT. ch. 38, $\S \S 4-3,-9$ (Smith-Hurd 1972); ME. REV. STAT. tit. 17-A, § 34(1), (5) (1981); N.Y. PeNal. LAW $\S \S 15.05, .15(2)$ (McKinney 1975); OHro Rev. Code ANN. \$ 2901.21(B) (Page 1975).

The provisions specifying that recklessness or a higher culpability satisfies the mental element are superior to the provisions that allow a court to read in any culpability. First, the former approach assures that negligence is not punished absent a specific legislative judgment. Second, it also assures that the court may not set the culpability requirement higher than the legislature may have intended. Third, the specific designation approach is easier to apply in practice and provides more consistency and predictability. Compare these statutes with those cired at note 84 supra, which always require culpability as to every element of a criminal offense and specify the applicable culpability term where none is stated, and with Colo. REV. STAT. § 18-1-502 (1978) (not even creating a presumption of required culpability).

159. The position of the court in such a jurisdiction can be analogized to the pre-Code situation in which a court was required to determine the level of culpability where none was specified. See note 51 supra. Previously, however, the court would have been governed by common law rules that would typically require recklessness as a minimum level of culpability. See, e.g., Eggman v. Scuurs, 311 N.W.2d 77 (lowa 1981) (mens rea is an element of every offense). See generally Model Penal Code $\$ 2.02(3)$ comment 4, at 127 (Tent. Draft No. 4 , 1955). The provisions that allow the court to select any culpability term, see note 158 supra, do not bar the court from deviating as its discretion from the recklessness norm.

160. The propriety of criminal liability for negligence is open to debate. See note 60 supra. Negligence is rarely an acceptable basis for criminal liability. See, e.g., Model PeNal CODE $§ 2.02$ comment 4, at 127 (Tent. Draft No. 4, 1955); see also note 87 supra. 
F. Conceptual and Practical Difficulties with Model Penal Code Section 2.02(4): Applying a Stated Culpability Term to All Elements of an Offense

Model Penal Code section 2.02(4) provides that where an offense definition specifies one culpability term, the term shall be applied to all elements of the offense, unless a contrary purpose plainly appears. ${ }^{161}$ The commentary supports this provision as one that will embody the most probable legislative intent. ${ }^{162}$ Scholars have praised the provision as one that eliminates the gross disparities that may occur between the culpability requirements of different elements of the same offense. ${ }^{163}$ In reducing disparity, however, the provision may well go too far, allowing in some instances an exceptional culpability requirement, which is intended to apply only to one element of the offense, to govern the culpability requirements for the other offense elements.

Consider, for example, the offense of burglary. An actor commits burglary when he "enters a building or occupied structure . . . with purpose to commit a crime therein, unless the premises are at the time open to the public or the actor is licensed or privileged to enter." 164 As "purpose" is the only culpability element prescribed and as no contrary legislative purpose plainly appears, Model Penal Code section 2.02(4) would seem to require that the actor must act purposely with respect to each element. ${ }^{165}$ In other words, the actor must be aware of or believe or hope that all the circumstance elements

161. Section 2.02(4) provides that:

Prescribed Culpability Requirement Applies to All Material Elements. When the law defining an offense prescribes the kind of culpability that is sufficient for the commission of an offense, without distinguishing among the material elements thereof, such provision shall apply to all the material elements of the offense, unless a contrary purpose plainly appears.

Model Penal. Code $\S 2.02$ (4) (Proposed Official Draft 1962) (emphasis added).

162. Model Penal Code $\S 2.02$ comment 6, at 129 (Tent. Draft No. 4, 1955) (the "normal probability" is that an articulated culpability requirement "was designed to apply to all material elements").

163. Wechsler stresses that the virtue of addressing culpability with respect to each of fense element is that it invites attention to the wisdom of "stark distinctions as to culpability respecting different elements of an offense." Wechsler, supra note 31 , at 1437 . He explains that $\$ 2.02(4)$ is "an attempt to promote uniformity on the issue." Id.; see also Williams, The Mental Element in Crime: The Law Commission's Report No. 89: (I) The Meaning of Terms, 1978 CRIM. L. REV. 588, 590-91 (criticizing the Law Commission for failing to resolve ambiguities and for not adopting a provision similar to Model Penal Code $\$ 2.02(4)$ ).

164. Model Penal Code $\S 221.1$ (1980).

165. MOdel Penal Code $\$ 2.02(4)$ (Proposed Official Draft 1962). For the text of $\S 2.02(4)$, see note 161 supra. 
exist. ${ }^{166}$ But burglary is typically understood to require purpose only as to the "intent to commit a crime therein."167 "Purpose" is an unusually stringent culpability requirement; "acting knowingly is ordinarily sufficient." 168 There are a few areas where legislatures want a stringent, "purposeful" requirement; in these areas the awkward concept of "specific intent" has traditionally been used. ${ }^{169}$ A straightforward application of section 2.02(4), however, would allow the exception to become the rule.

\section{G. Confict and Inconsistency Between Model Penal Code Sections 2.02(3) and 2.02(4): Element Analysis vs. Offense Analysis}

Model Penal Code section 2.02(3) requires recklessness whenever the offense definition fails to specify the culpability with respect to a particular element. ${ }^{170}$ On the other hand, when the offense definition specifies only one culpability element, section $2.02(4)$ requires that this culpability requirement apply to all objective elements of the offense, unless a contrary purpose plainly appears. ${ }^{171}$ Consider the definition of harassment:

A person commits a petty misdemeanor if, with purpose to harass another, he . . . insults . . . another in a manner likely to provoke violent or disorderly response. ${ }^{172}$

If section 2.02(3) is applied, the defendant must be purposeful only as to harassing another, and need be only reckless with respect to all other elements. If section 2.02(4) is applied, the actor must act purposely with respect to all elements. For the reasons stated above, the section 2.02(3) recklessness requirement should be preferred. Section 2.02(4) should apply only when the placement and effect of the stated culpability term suggest that it is intended to govern the culpability requirements for the other offense elements.

166. See Model Penal Code $\$ 2.02$ (2) (a)(ii) (Proposed Official Draft 1962).

167. "[B]urglary, though a crime exclusively of intention in respect of the felony to be committed in the house, is also a crime of recklessness (perhaps even strict responsibility) in respect of the time and place." G. WILLIAMS, supra note $7, \S 22$, at 52 ; see Karlen, supra note 146 , at 238; Mueller, supra note 60 , at 1062 . While it may be interesting to question the wisdom of stark distinctions between culpability elements of the same offense, see note 163 supra, the intent accompanying burglary illustrates that some difference in levels among the elements of an offense may be appropriate.

168. Model Penal. Code $\$ 2.02$ comment 3, at 125 (Tent. Draft No. 4, 1955).

169. Id.; see also id. $\$ 2.02$, comment 1 , at 124 (noting that the "purpose" requirement in rape does not extend to lack of consent).

170. See notes 155-60 supra and accompanying text.

171. See notes 161-69 supra and accompanying text.

172. Model Penal Code $\S 250.4(2)$ (1980). 
The conflict between sections 2.02(3) and 2.02(4) reflects the two modern forms of the definition of offenses - element analysis and offense analysis - described in Part I of this Article. In providing that any stated culpability level applies to all elements of the offense, section 2.02(4) is characteristic of an offense analysis model of offense definition. Section $2.02(3)$, on the other hand, reflects the element analysis approach adopted in sections $2.02(1)$ and $2.02(2)$, which allow and facilitate the application of different culpability requirements to different elements of the same offense. Section 2.02(3) is, in fact, central to the implementation of element analysis. It assures that each objective element has an accompanying culpability requirement, but does not assume that such culpability is the same for each different element.

The coexistence of these two disparate models in different subsections of section 2.02 suggests that the drafters of the Code were either ambivalent about the merits of their element analysis innovation or simply carelessly inconsistent in effecting it. This inconsistency extends beyond the conflicting subsections of section 2.02; several other provisions of the Code appear to require offense analysis. In each instance, the provision improperly assumes that a single level of culpability will always suffice to establish culpability for an offense. For example, an actor who is reckless or negligent in forming a belief as to the justifiability of his own use of force is denied a justification defense if "recklessness or negligence, as the case may be, suffices to establish culpability for the offense charged." 173 Similarly, an actor who is reckless or negligent either in causing the situation that requires a choice of evils or in appraising the need for conduct to protect himself from harm, is deprived of the choice of evils defense "in a prosecution for any offense for which recklessness or negligence, as the case may be, suffices to establish culpability." ${ }^{174}$ As a final illustration, one who is negligent in placing himself in a situation where coercion is probable is deprived of the duress defense "whenever negligence suffices to establish culpability for the offense charged."175

In presuming that a single level of culpability can "suffice[] to establish culpability" for an offense, these provisions are predicated on the offense analysis model and not on the Code's element analysis scheme. Arguably, the quoted phrase "recklessness or negligence" is designed to refer to one of the several culpability requirements of an

173. Model Penal Code $\S 3.09(2)$ (Proposed Official Draft 1962).

174. Id $\$ 3.02(2)$.

175. Id. $\S 2.09(2)$. 
offense definition. But if this is the design, should these provisions turn on the highest level of culpability required for any element of the offense, the lowest level of culpability, the level most commonly required among all elements, or the culpability required as to some particular objective element-such as a result element, if present? ${ }^{176}$

176. There are difficulties with each of these suggested constructions of the phrase "suffices to establish culpability for the offense charged."

First, if the highest level of culpability is the culpability that suffices, the provisions discussed in the text are only meaningful where the offense charged either does not require culpability as to conduct or does not contain a conduct element. Recall that recklessness and negligence are not defined with respect to conduct; where a Model Penal Code offense definition requires culpability as to conduct, knowledge is the minimum level of culpability. Thus, where culpability as to conduct is required, as it always is, neither recklessness nor negligence will be the highest level of culpability.

Second, if the lowest level of culpability is the level that "suffices to establish culpability," then Model Penal Code $\$ \$$ 3.02, 3.09 (Proposed Official Draft 1962), would be available to bar justification defenses where the defendant is charged with an offense that requires either recklessness or negligence as to a culpability element, even if purpose or knowledge is required for other elements of the offense. See text accompanying notes 173-74 supra. Similarly, $\$ 2.09$ would be available to bar a duress defense if the defendant is charged with any offense that requires negligence as to any objective element. But these results seem anomalous. For example, under the Model Penal Code, "simple assault" is committed if a person "purposely, knowingly, or recklessly causes bodily injury to another." MODEL PENAL CODE $\$ 211.1$ (1)(a) (1980). "Aggravated assault" is committed if a person "purposely or knowingly causes bodily injury to another with a deadly weapon." Id. $\$ 211.1$ (2)(b). The latter offense requires only recklessness as to the circumstance element "deadly weapon," but clearly requires purpose or knowledge as to the result element "bodily injury." See MODEL PENAL CODE $\$ 2.02$ (3) (Proposed Official Draft 1962); notes 83-94 supra and accompanying text. Thus, if the lowest culpability is the "culpability that suffices," a defendant could be convicted of aggravated assault if he recklessly appraised the need for self-defense and responded with a deadly weapon. Yet, this result would seem to undermine the distinction the drafters have made between simple and aggravated assault. Recklessness as to causing "bodily injury" only suffices to establish aggravated assault "under circumstances manifesting extreme indifference to the value of human life." Model Penal CODE $\$ 211.1$ (2)(a) (1980). If the defendant shot at another's foot, recklessly (and mistakenly) believing the victim to be an attacker, simple assault would seem to be the appropriate charge.

Third, if the most common level of culpability is the level that "suffices to establish culpability," the provision is merely mechanical and seems absurd. For example, the definition of burglary contains many circumstance elements as to which the actor need only be reckless. These elements far outnumber the single purpose requirement in the offense definition. Y'er who would conclude that the drafters meant recklessness to be the culpability that "suffices to establish the culpability" for burglary?

Fourth, if some kgy element "suffices to establish culpability," the phrase is fraught with ambiguity. For example, is the key element in burglary the entry or is it the purpose to commit a crime? The purpose to commit a crime is only punishable if accompanied by the entry, or if the actor satisfies the elements of attempt or conspiracy. The truth is that neither element is key but that both elements in combination are central and that both, together with all other elements, are necessary to accurately describe the harm of burglary. For example, an entry alone constitutes at most criminal trespass. See generally O.W. HOLMES, THE COM- 
The commentary does not explain. ${ }^{177}$ It is possible that the drafters of these other sections of the Code lacked a full understanding of the culpability concepts embodied in section 2.02, or were unfamiliar with that section's commitment to an element analysis culpability scheme. ${ }^{178}$

To confirm that the Code is indeed inconsistent, one can find several sections which, although analogous in function to those cited above, employ element analysis. One such section, for example, provides that a voluntarily intoxicated actor cannot claim that his intoxication negates an element when recklessness establishes that element. ${ }^{179}$ In proper element analysis fashion, this provision requires an examination of the actor's culpability with respect to each element, implicitly recognizing that the requisite culpability may vary. ${ }^{180}$ Similarly, section 2.05(2)(a) of the Code classifies as a mere "violation" any offense for which absolute liability is imposed "with respect to any material element of an offense," ${ }^{181}$ thereby recognizing that the culpability requirements for different elements may be different. Section 2.05(2)(b) similarly speaks of absolute liability imposed by law "with respect to one or more of the material elements of

MON LAW 146 (M. Howe ed. 1963) (noting that the criminality of a certain course of conduct depends on the totality of the circumstances; acts themselves are indifferent).

All of the suggested constructions of the phrase "suffices to establish culpability" share a common flaw that is inherent in the statutory phrase: The phrase suggests that the culpability required for an offense can be characterized by a single culpability level. This "offense analysis" approach ignores the Code drafters' view of culpability: "[C]lear analysis requires that the question of the kind of culpability required to establish the commission of an offense be faced separately with respect to each material element of the crime." MODEL PENAL CODE $\S 2.02$ comment 1 , at 123 (Tent.Draft No. 4, 1955).

177. Section 2.02(10) offers some guidance: "When the grade or degree of an offense depends on whether the offense is committed purposely, knowingly, recklessly or negligently, its grade or degree shall be the lowest established with respect to any material element of the offense." Model Penal Code $\S 2.02(10)$ (Proposed Official Draft 1962). This provision is only useful, however, where the grade or degree of the offense depends on the level of culpability. Further, the provision does not state a rule for determining the culpability that "suffices to establish" such an offense; it merely states a rule for determining the degree or grade of the offense.

178. The culpability scheme was included in Tentative Draft No. 4 and considered at the 1955 meeting of the Institute. The justification provisions discussed here, MODEL PENAL CODE $\$ \S 3.02,3.09$ (Proposed Official Draft 1962), were included in Tentative Draft No. 8 and presented in 1958. The duress defense, contained in $\S 2.09$, was included in Tentative Draft No. 10 and presented in 1960. Thus, the element analysis scheme was available, but was not used.

179. See Model Penal Code $\S 2.08(2)$ (Proposed Official Draft 1962).

180. See, e.g., text accompanying note 81 supra. See generally notes 155-69 supra and accompanying text.

181. Model Penal Code $\S 2.05(2)$ (a) (Proposed Official Draft 1962). 
an offense . . ."182 The intoxication and absolute liability provisions illustrate the feasibility of drafting provisions that effectuate element analysis and provide a model for redrafting provisions that improperly regress to an offense analysis scheme.

\section{Element Analysis in Defining Criminal Liability}

As Part IV makes clear, the Model Penal Code's implementation of the element analysis concept is seriously flawed, if not entirely unworkable. But the significant advantages of such an approach make it worth salvaging, if possible. This part of the Article proposes, in section A, a culpability scheme that resolves most of the difficulties with the Model Penal Code provisions. Section B discusses the relationship between culpability requirements under element analysis and the law of mistake and concludes that the latter is for the most part rendered obsolete by a comprehensive culpability scheme.

Sections C, D, and E take up the three most important general provisions that impose criminal liability-the provisions defining complicity, attempt, and conspiracy liability. Each section offers an element analysis critique of the governing Model Penal Code provisions to illustrate the Code's weaknesses and ambiguities. Then, drawing upon case law to determine the current consensus, if any, on substantive issues, each section proposes an element analysis formulation for the provisions.

\section{A. A Proposed Scheme for Defuning Offenses}

Nearly all of the difficulties with the Model Penal Code scheme described in Part IV can be avoided with the following revisions. These revisions not only make the Code's fundamental scheme workable, but they also reflect a sounder theoretical position than that of the Code. Five revisions are urged.

First, "conduct" elements should be defined literally, and thus narrowly, to mean pure conduct, that is, to mean the actual physical movement of the actor. Thus, objective elements of an offense definition that might otherwise be classified as conduct elements, but which actually describe characteristics of the conduct-i.e., elements concerning the "nature of conduct"183 — should be treated as circum-

182. Id. $\S 2.05(2)$ (b). Similarly, Model Penal Code $\S 2.05(1)(\mathrm{b})$ speaks of absolute liability "for such offenses or with respect to any material element thereof . . . " /d. $\S 2.05(2)$ (b) (emphasis added). For a Code provision that is ambiguous on this issue, see id. $\S 2.06(2)$ (a). For a discussion of $\S 2.06(2)$ (a), see notes 231-78 infra and accompanying text

183. See Model Penal Code $\$ 2.02(2)$ (a)(i), (b) (i) (Proposed Official Draft 1962) (de- 
stance elements. For example, according to the definition of harassment, a person commits an offense if he "insults ... another in a manner likely to provoke violent . . response."184 Here, the conduct element is the simple act of speaking; the conduct's characteristics-its insulting character, its likelihood of provoking a violent response--should be treated as circumstance elements.

As a corollary to this first revision, whenever a single verb compounds a conduct element with a result element or a conduct element with a circumstance element, the legislature should redraft the language to express each element in a separate word. Absent such redrafting, courts should separate the elements by interpretation. ${ }^{185}$ This approach also clearly identifies where result elements in fact exist and, therefore, where the special requirements of causation apply. ${ }^{186}$

The conduct element therefore emerges as a relatively unspecific and unimportant aspect of an offense. In homicide, for example, the particular conduct the actor engages in to cause the death of another human being does not matter. ${ }^{187}$ What matters is that the actor's conduct, of whatever nature, did cause the prohibited result. The

fining "purposely" and "knowingly" with respect to the nature of conduct). For a discussion of the ambiguity surrounding the proper scope of conduct elements under the relevant Model Penal Code provisions, see notes $119-20$ supra and accompanying text.

184. Model Penal Code $\S 252.4(4)$ (1980).

185. This proposal does not require that all offense definitions be rewritten literally to separate the conduct elements and the result elements. Yet this can be and has been done. The proposed federal criminal code, for example, provides that an actor commits homicide when he "[1] engages in conduct [2] by which he . . . causes the dearh of another person." $S$. 1437,95 th Cong., 2d Sess. $\$ 1061(a)(1)-(2)(1978)$. As long as the conduct and result elements are understood to be distinct, terms such as "kills," "damages," "destroys," and "desecrates" may properly be retained.

186. See Model. Penal Code $\$ 2.03$ (Proposed Official Draft 1962) (defining the necessary causal relationship between conduct and results). The existence of hidden result ele ments may obscure the necessity of establishing the requisite causal relationship. Consider the offense of indecent exposure. See text accompanying note 81 supra. The offense requires that the actor, with the purpose of arousing sexual desire, expose his genitals-i.e., engage in conduct by which he causes his genitals to be exposed under circumstances in which he knows his conduct is likety to cause affront. If an actor, with purpose of arousing sexual desire, exposes anther part of his body, the offense is not committed. Suppose that a young man, with the requisite purpose, intends to "moon" a passerby and, as he does so, is knocked by a prankster friend into a position in which he exposes his genitals to, rather than merely "moons," the passerby. The prosecution must then establish that the actual result. exposure of his genitals, "is not too remote or accidental in its occurrence to have a [just] bearing on the actor's liability ... . "Id $\$ 2.03(2)$ (b) (brackets in original). If one views "expose" as a conduct element, however, this requirement will be bypassed.

187. See People v. Dixie, 98 Cal. App. 3d 852, 856, 159 Cal. Rptr. 717, 720 (1979) (means of commission is not an element of homicide). 
most significant elements of an offense definition, then, are the circumstance and result elements.

This narrowly defined conduct element will still adequately serve the important purposes of an act requirement: to limit omission liability, ${ }^{188}$ to give a point of reference for such collateral issues as the statute of limitations, ${ }^{189}$ to permit enforcement of the concurrence requirement, ${ }^{190}$ to establish jurisdiction ${ }^{191}$ and venue, ${ }^{192}$ and to help distinguish single and multiple offenses for the application of double jeopardy and related multiple offense limitations. ${ }^{193}$ Moreover, because it provides a more definite and specific point of reference, this narrow definition of conduct may satisfy many of these purposes more effectively than would the broader definition of conduct elements. ${ }^{194}$

The second revision, which follows logically from the narrow scope of the conduct element definition, is to give the culpability re-

188. The act requirement defines those cases in which the special requirements of omission liability-proof of a duty and the capacity to perform the required act-are not imposed. See, e.g., Model Penal CoDe $\$ 2.01(1)$, (3) (a) (Proposed Official Draft 1962) (conduct establishing liability must include a voluntary act or an omission to perform an act that the actor is physically capable of performing and has a duty to perform).

189. Sec, e.g., id. $\$ 1.06(4)$ ("[a]n offense is committed . . . when every element occurs"). A narrow definition of conduct facilitates the determination of whether the necessary conduct
element of the offense has occurred.

190. The concurrence requirement prohibits labeling conduct as criminal unless the required mental culpability exists at the time of the required conduct. See J. HalL, supra note 20 , at 179. Where the definition of conduct is broad, the application of the concurrence requirement is more difficult. Cf. W. LAFAVE \& A. SCOTT, supra note $7, \S 34$, at 241 (If attention is not focused upon the proper act it may appear that the concurrence requirement has not been met. Or, it may appear that it has been satisfied when it has not.). For example, if one were to define conduct broadly to include the accompanying circumstances and results, see J. HALL, supra note 20, at 172-73 (describing Salmond's definition of act), a person who accidentally wounded another in a hunting accident could be held liable for intentional homicide if he later learned the victim's identity and hoped that the victim would die while en route to the hospital. There would then be concurrence between the death, the required result, and the actor's conscious desire for the death, the required mens rea.

191. See Model Penal Code \$ 1.03(1)(a) (Proposed Official Draft 1962) (describing jurisdiction in terms of the place of either the conduct or the result).

192. See, eg., N.M. STAT. ANN. \$30-1-14 (1978) (trial may be held in any county in which a material element of the offense is committed). Thus, venue is proper where the
conduct element of an offense occurs.

193. "When the same conduct of a defendant may establish the commission of more than one offense, the defendant may be prosecuted for each such offense." MODEL PENAL CODE $\$ 1.07$ (1) (Proposed Official Draft 1962) (emphasis added). Where two offenses arise from the "same conduct," however, the defendant may usually be convicted of only one unless each offense "requires proof of a fact which the other does not." Blockburger v. United States, 284 U.S. 299, 304 (1932).

194. For a discussion of the conduct-result problem in the context of the concurrence requirement, see note 190 supra. 
quirement accompanying the conduct element a similarly narrow meaning and to recognize it as having little practical significance. Since conduct encompasses only a simple act, not the circumstances accompanying or the results following the act, the culpability requirement for the conduct should encompass only the mental state as to the simple act and not as to the circumstance or result. Otherwise, "knowing" conduct_-"being aware of the nature of" one's conduct ${ }^{195}$ - could be all-encompassing, possibly requiring that the actor be aware of the pertinent attendant circumstances of his conduct or be aware that the pertinent result is likely to follow from his conduct. But, insofar as the Model Penal Code gives a definition of "knowing" as to circumstance and result elements different from that it gives as to conduct elements, such a broad interpretation of culpability as to conduct would short-circuit this definitional scheme and thereby undermine element analysis generally.

Under the narrow definition of conduct, the accompanying culpability-being aware of one's conduct-mimply requires, for example, that an actor be aware that he is moving his trigger finger or swinging his arm. In other words, conduct culpability does nothing more than encompass the voluntariness requirement of Model Penal Code section 2.01 and is therefore superfluous. ${ }^{196}$ Perhaps more important, the only cases at issue under such a narrowly defined conduct element would involve an actor suffering a considerable disability-e.g., an actor who is unaware that he is moving his finger or arm. Such abnormalities require detailed consideration, and distinct provisions, such as the voluntariness requirement, or excuse defenses, such as insanity, can and do permit more detailed

195. See Model Penal Code $\$ 2.02(2)$ (b) (i) (Proposed Official Draft 1962). For a discussion and expositions of the definition of culpability terms with respect to different kinds of objective elements of an offense, see notes $52-64,81-82$ supra and accompanying texts; text accompanying notes $65-80$ supra.

196. $\$ 2.01(1)-(2)$ provides that:

(1) A person is not guilty of an offense unless his liability is based on conduct which includes a voluntary act....

(2) The following are not voluntary acts...

(a) a reflex or convulsion;

(b) a bodily movement during unconsciousness or sleep;

(d) a bodily movement that otherwise is not a product of the effort or determination of the actor, either conscious or habitual.

Model Penal CoDe $\S 2.01(1)-(2)$ (Proposed Official Draft 1962). The Code's definition of "purposely" as to conduct-having as one's "conscious objective to engage in conduct of that nature," id. $\$ 2.02(2)(a)(i)$-is equally redundant after the voluntariness requirement of $\S 2.01$. See id. $\S \S 2.01(2)(\mathrm{d}), 2.02(2)(\mathrm{a})(\mathrm{i})$. 
consideration than can an offense definition. ${ }^{197}$ The culpability requirements of an offense definition, in contrast, are most effective at describing the liability of normal persons who are responsible for their conduct. ${ }^{198}$

Furthermore, such a narrow interpretation of conduct solves the problems created by the drafters' possibly inadvertent failure to define recklessness and negligence as to conduct. This solution is preferable to creating a definition of recklessness and of negligence as to conduct ${ }^{199}$ because the narrow definition of conduct proposed here is more consistent with the common meaning of that term as well as with its defined meaning in the Code. ${ }^{200}$ Once defined narrowly, this culpability requirement would be easily satisfied, and therefore generally would be unimportant in the average case.

Offense definitions, then, would consist primarily of a series of circumstance and/or result elements and their accompanying culpability requirements. ${ }^{201}$ This points to the importance of another reform. While the Model Penal Code contains excellent provisions that precisely define each level of culpability as to a circumstance or a result element, distinguishing circumstance elements from result elements can be difficult. ${ }^{202}$ The Code provides no guidance on this

197. This point no doubt will raise the persistent debate over the propriety of distinguishing culpability requirements of an offense definition from general excuses. I have argued elsewhere that such a distinction would be a theoretically useful one. See Robinson, Criminal Law Defenses: A Systematic Analysis, 82 Colum. L. Rev. 199, 203 (1982). Others disagree. For example, Hall states that: "If the defendant was insane at the time of the conduct in issue, the requisite mens rea was lacking and no crime was committed." J. Hall, supra note 20 , at 449 (italics omitted). My proposal, however, suggests only a particular drafting approach to defining liability; it does not depend on the outcome of the theoretical debate, nor does it dispute the conceptual similarities between culpability element issues and general
excuses.

198. Excuse defenses generally include requirements designed to distinguish an excused actor as abnormal, and therefore excusable, without undermining the general deterrent function of the criminal law. These requirements may be termed "disability elements." See Robinson, supra note 197, at 221 . To undercut an actor's responsibility, his disability must cause one of the four excusing conditions. Id. at 221-25. These excuse conditions provide the necessary protection for the truly "irresponsible" actor, while maintaining the integrity of the criminal prohibitions for normal actors.

199. See note 152 supra and accompanying text. For a discussion of whether the Model Penal Code defines these culpability terms with respect to conduct, see note 146 supra.

200. See Model Penal Code § 1.13(4)-(5) (Proposed Official Draft 1962). For a discussion of the Code's definition of conduct, see note 119 supra.

201. Turner attributed some of the confusion in the law of mens rea to the failure to distinguish the issue of the voluntariness of an act from the actor's attitude toward the consequences of his act. Turner, supra note 21 , at 34 . He concluded that only the latter inquiry was significant to the recognition of a mental element in crime.

202. For an illustration of the difficulty of distinguishing circumstance elements from 
issue. For example, is causing the "obstruction of a highway" a single result element? Or is it a result element of causing an "obstruction" and a circumstance element of "a public highway"?

To resolve such problems, the third revision would define a result as a circumstance changed by the actor. All elements that did not fit this definition would be independent circumstance elements. In the hypothetical above, the actor creates only the obstruction; he cannot create or alter the road's status as a "public highway." Under this revision, "causing an obstruction" would be a result element, and "public highway" would be a circumstance element. ${ }^{203}$

The net effect of these three revisions is to make the Model Penal Code culpability scheme notably easier to apply. In every offense, the conduct element, although perhaps linguistically merged with other elements, would simply perform the function of the act requirement. Result elements would be easy to detect; they would be circumstances changed by the actor. All other elements would be circumstance elements.

The fourth and fifth revisions concern unstated culpability requirements. Both flow from the fundamental premise of element analysis_different elements of the same offense may have different culpability requirements. The fourth proposal, governing those instances in which an offense definition expressly provides one or more culpability requirements, entirely eliminates section 2.02(4), a misbegotten section ${ }^{204}$ which now requires that any stated culpability term be applied to all elements of an offense. ${ }^{205}$ This proposal replaces that section with the following provision: A stated culpability term should apply to the remainder of only the particular grammatical clause in which it appears unless the context plainly demonstrates that it is intended to apply to other, subsequent clauses as well. ${ }^{206}$ In

result elements, see notes $113-27$ and accompanying text. Criminal homicide, for example, is generally defined to include causing "the death of another human being." MODEL Penal CODE $\S 210.1$ (1980). It is not clear, however, whether the result element is "death of a human being," or whether the result is "death," and "human being" is a circurnstance element.

203. It is not necessary here to determine whether there are one or two circumstance elements in "public highway." The same culpability definition will apply to both. See notes 52-82 supra and accompanying text.

204. See notes 161-69 supra and accompanying text.

205. Model Penal CoDe $\$ 2.02$ (4) (Proposed Official Draft 1962). For a discussion of this Code section, see notes 91-94, 161-82 supra and accompanying texts.

206. See notes 170-82 supra and accompanying text (proposing that Model Penal Code $\$ 2.02(4)$ should be read in such a manner); text accompanying notes 85-87 supra (applying such a rule of construction in interpreting the definition of indecent exposure). 
order for this fourth revision to be effective, it must rely on the fifth, and final, revision to complete the scheme. The fifth proposal provides that recklessness is the appropriate mental state requirement for all unstated culpability requirements without regard to the culpability requirements specified for other offense elements, unless the legislature more specifically expresses a contrary purpose. For example, in the absence of legislative direction to the contrary, recklessness would be required as to the circumstance element of an unlicensed or unprivileged entry in burglary. This proposal incorporates the Model Penal Code position that the culpability level of recklessness should be applied when the required culpability is unstated, a position that is appropriate because recklessness is generally accepted as the appropriate norm for imposing criminal liability. ${ }^{207}$

Thus, the fourth and fifth revisions neither raise $^{208}$ nor lower ${ }^{209}$ the culpability requirements that are stated in an offense definition. They are, rather, drafting techniques by which the legislature can, as effectively, as easily, and as clearly as possible, define the culpability requirements it desires. If a culpability requirement other than recklessness is to apply to a particular element, the legislature need only state such culpability requirement in the offense definition. Under the proposal, the legislature may state the requirement without fear that it will be mistakenly interpreted to apply to all of the elements.

\section{B. Element Analysis and Mistake}

Offense analysis relies on the law of "mistake" to resolve most

207. See note 87 supra and accompanying text.

208. Some would argue that in the absence of a stated culpability requirement, only strict liability need be proven. See W. LAFAvE \& A. ScOTT, supra note 7, \$31, at 219 (noting that courts sometimes hold "that the statute means what it says and so imposes criminal liability without regard to fault"); cases cited at note 51 supra (trial courts imposed strict liability by applying stated culpability term to the conduct element alone). See generally $W$. LAFAVE \& A. SCOTT, supra note 7, \&31, at 219-22 (analyzing the factors courts consider in evaluating offenses defined without a stated culpability term). But most would agree that liability for negligence is, and nearly all would agree that strict liability is, inappropriate except in rare cases. See notes 87-88 supra and accompanying text.

209. Those supporting a literal reading of Model Penal Code $\$ 2.02(4)$ may claim that this interpretation would improperly reduce the culpability requirements for the many offenses with intent requirements specifically stated. The commentary to $\$ 2.02(4)$ states that, "The draft proceeds in the view that if a particular kind of culpability had been articulated at all by the legislature . . the normal probability is that it was designed to apply to all material elements." MOdel PeNal Code $\$$ 2.02(4) comment 6, at 129 (Tent. Draft No. 4, 1955). Of course, this nonliteral reading of $\$ 2.02(4)$ would result in higher culpability requirements than would a literal reading where an offense required negligence or strict liability as to one element. 
unanswered questions concerning the culpable state of mind requirements for liability. ${ }^{210}$ Under element analysis, however, determining whether a reasonable or an unreasonable mistake as to a particular circumstance will provide a defense requires nothing more than determining what culpable state of mind is required as to that circumstance element. The Model Penal Code expressly recognizes the interdependence, and indeed the interchangeability, of culpability requirements and mistake defenses when it provides that "[i]gnorance or mistake as to a matter of fact or law is a defense if ... the ignorance or mistake negatives the purpose, knowledge, belief, recklessness, or negligence required to establish a material element of the offense." 11 Many states have similar provisions. ${ }^{212}$

Technically, such provisions are unnecessary. They simply confirm what is stated elsewhere: "No person may be convicted of an offense unless each element of such offense is proven beyond a reasonable doubt." 213 If the defendant's ignorance or mistake makes proof of a required culpability element impossible, the prosecution will

210. "It is true, of course, that whether recklessness or negligence suffices as a mode of culpability with respect to a given element of an offense is often raised for the first time in dealing with a question of mistake." MOdel Penal CoDe $\$ 2.04$ comment 1 , at 136 (Tent. Draft No. 4, 1955); see, e.g., Regina v. Prince, 2 L.R.-Cr. Cas. Res. 154 (1875) (requisite culpability as to victim's age discussed because defendant raised a defense of reasonable mistake as to age). Regina v. Prince is discussed at notes 19-20 supra and accompanying text.

211. Model Penal Code $\S 2.04(1)$ (a) (Proposed Official Draft 1962). The mistake defenses relevant to culpability elements are those that negate such elements. All references here to mistake and mistake defenses are to this limited area of the law of mistake. Mistake defenses, such as those based upon the unavailability of a law or upon reliance upon an official misstatement of the law, are general defenses that are available even when the defendant has satisfied the elements of the offense. For a discussion of the distinction between general excuse defenses and defenses negating an offense element, see Robinson, supra note 197, at 205 .

212. See, e.g., Criminal Code of $1961, \S 4-8(a)$, Ill. ANN. STat. ch. 38, § 4-8(a) (SmithHurd 1972); Kan. STAT. ANN. \$ 21-3203(1) (1974); WIS. STAT. ANN. $\$ 939.43(1)$ (West 1982). Many other jurisdictions adopt a variation of the Model Penal Code approach and permit only factual mistakes to negate an element. See ALASKA STAT. $§ 11.81 .620(\mathrm{~b})(1)(1978)$; ARIZ. REV. StAT. ANN. § 13-204(A)(1) (1978); Colo. Rev. STAT. § 18-1-504(1)(a) (1978); Conn. Gen. Stat. ANN. \$ 53a-6(a)(1) (West 1972); Del. Code ANN. tit. 11, § 441(1) (1979); GA. Code ANN. $§ 26-705$ (1977); Hawali Rev. Stat. $§ 702-218(1)$ (1976); N.H. Rev. STAT. ANN. § 626.3(I)(a) (1974); N.Y. Penal LaW § 15.20(1)(a) (McKinney 1975); UTAH Code ANN. $\$ 76-2-304$ (1) (1978). But see In re Luis C., 66 Misc. 2d 107, 323 N.Y.S.2d 267 (Crim. Ct. 1971) (because actual knowledge of illegality of the entry is an element of criminal trespass, mistake as to legality is a defense).

213. Model Penal CoDe $\$ 1.12(1)$ (Proposed Official Draft 1962) (requiring the prosecution to prove each element of the offense beyond a reasonable doubt); see also Robinson, supra note 197, at 204 n. 10 (lists jurisdictions that codify this standard of proof). 
necessarily fail in its proof of the offense. ${ }^{214}$ Assume, for example, that incest is defined as "having intercourse with a person the actor knows to be an ancestor, descendent, or sibling." 215 If the evidence suggests that the defendant honestly believed that the person with whom he was having intercourse was entirely unrelated to him, the prosecution will be unable to prove, as required, the defendant's knowledge of his familial relationship to his partner; the defendant's mistake will provide a "defense."216

Offense analysis resolves the issue of mistake as to family relation in an incest prosecution under what is perceived to be an independent law of mistake, developed primarily by the courts. But such a "law of mistake" violates the notice and precision requirements of the legality principle and improperly delegates to the courts a criminalization decision that belongs to the legislature. ${ }^{217}$ Element analysis, in contrast, clearly defines every culpability requirement as to every objective element, thus avoiding these criticisms.

Habit will no doubt provide a continuing temptation to speak of mistake defenses rather than culpability requirements. Element analysis does not require using the "culpability requirement" rather than "mistake defense" terminology. The choice is simply one between a positive and a negative statement of the issue. The former focuses on what will suffice to establish liability, the latter on what will suffice to

214. For a general discussion of "failure of proof" defenses, see Robinson, supra note 197, at 204-08.

215. E.g., Colo. Rev. Stat. $§ 18-6-301$ (1978); Model Penal Code $\$ 230.2$ (1980).

216. The defendant may, as a practical matter, have to act affirmatively to raise the mistake issue in order to carry the burden of pleading, see Robinson, supra note 197, at 250 \& n. 189 , or to undercut the prosecution's prima facie case. But this is true whenever the defendant seeks to negate an offense element, not just in those situations where we would describe defendant's rebuttal evidence as a "mistake defense." Whether the defendant will be obliged to present evidence on the issue will not depend on any special characteristic or status of the mistake as a "defense," but rather it will depend on whether the prosecutor can introduce evidence suggesting that the required culpability element does exist. See Jackson v. Virginia, 443 U.S. 307, 319 (1979); notes 13-14 supra. A mistake negating an element, however, is not a true defense. See note 218 infra.

The Model Penal Code also permits code drafters to write a specific mistake defense into an offense provision. MODEl PENAL CODE $\S 2.04$ (1)(b) (Proposed Official Draft 1962); accord Ala. Code $\S 13 A-2-6(a)(2)$ (1982); Alaska Stat. $\$ 11.81 .620(b)(2)$ (1978); Ark. StaT. AnN. § 41-206(1)(a) (1977); Colo. Rev. Stat. § 18-1-504(1)(b) (1978); ConN. Gen. STAT. AnN. $\S 53 a-6(a)(2)$ (West 1972); Del. Code ANn. tit. 11, §441(2) (1979); Hawail Rev. Stat. $\S 702-218(2)$ (1976); KY. REv. STAT. $\$ 501.070(1)$ (b) (1975); N.H. REV. Stat. ANN. $\S 626: 3(\mathrm{I})(\mathrm{b})$ (1974); N.J. STAT. ANN. $\S 2 \mathrm{C}: 2-4(\mathrm{a})(2)$ (West 1982); N.Y. PENAL LAW $\S 15.20(1)$ (b) (McKinney 1975); 18 PA. Cons. STAT. ANN. $\S 304$ (2) (Purdon 1973). But since a drafter may write any culpable state of mind requirement into any offense definition or element thereof, such an approach is unnecessary.

217. See notes 100-01 supra and accompanying text. 
prevent liability. ${ }^{218}$ Columns 1 and 2 of Chart II show the ease with which "requirements" translate into "defenses." If recklessness, for example, as to a circumstance element inculpates, then a merely negligent or faultless mistake as to that circumstance provides a defense.

\section{Chart II: Culpability Requirements and Mistake Defenses}

1. Culpability $\underline{\text { Requirement }}$

"purposely"

"knowingly"

"recklessly"

"negligently"

absolute

liability
2. Will Be Negated by (i.e., actor will get defense for):

any mistake

any mistake (i.e., reckless, negligent, or faultless)

a negligent or faultless mistake

a faultless mistake no mistake (not even faultless)
3. In Language of "Reasonable" and

"Unreasonable" Mistake, Will Be Negated by (i.e., actor will get defense for):

any mistake

any mistake (i.e., reasonable or unreasonable)

an unreasonable (in the sense of a "negligent"*) or a reasonable mistake

a reasonable mistake

no mistake (not even reasonable)

"There is no defense, however, for an unreasonable, in the sense of a "reckless." mistake. It is this point at which the reasonable-unreasonable terminology breaks down in its translation of modern culpability terms. This is a particularly serious error given the fact that "recklessly" is the norm, the most common culpability required as to circumstance elements.

Some people may have to adjust their usual terminology to speak of reckless and negligent mistakes, but this language has the advantage of drawing upon the precise culpability definitions of most modern codes. An actor makes a "reckless mistake" if he is not substantially certain that an element exists, but is aware of a "substantial . . . risk that the ... element exists." "219 An actor makes a "negligent mistake" if he is not, but should be, aware of a substantial risk that the element exists, and such unawareness is "a gross devia-

218. The term "defense" is used here in its broad sense. A mistake negating an element is not truly a "defense," as that term is more appropriately used to refer to general defenses that bar liability although the elements of an offense have been satisfied. See Robinson, supra note 197 , at 203.

219. Model Penal Code $\$ 2.02(2)$ (c) (Proposed Official Draft 1962). See notes 73-76 supra and accompanying text. 
tion from the standard of care that a reasonable person would observe in the actor's situation." 220 An actor makes a "faultless mistake" if he is neither reckless nor negligent, as defined above, as to the existence of an element.

The Model Penal Code and most modern codes do not always take advantage of these clear terms. They frequently revert to the common law terminology of "reasonable and unreasonable" mistakes, as if these mistakes were unrelated to the culpability requirements provided in the offense definitions. ${ }^{221}$ This failure to see the interchangeability of culpability requirements and mistake defenses is yet another example of the drafters' failure to understand the full implications of their element analysis scheme.

One can roughly translate the "reasonable" and "unreasonable" mistake language into the culpability requirement of the Code. But as column 3 of Chart II illustrates, the translation is uncertain at its most critical point: in determining the kind of mistake that provides a defense when recklessness, the most common culpability level, as to a circumstance is required. Recall that a negligent or faultless mistake negates (necessarily precludes the existence of) recklessness. While a "negligent mistake" may be said to be an "unreasonable mistake," all "unreasonable mistakes" are not "negligent mistakes." A mistake may also be unreasonable because it is reckless. Reckless mistakes, although unreasonable, will not negate recklessness. Thus, when offense definitions require recklessness as to circumstance elements, as they commonly do, the reasonable-unreasonable mistake language inadequately describes the mistakes that will provide a defense because of the imprecision of the term "unreasonable mistake." Reckless-negligent-faultless mistake language is necessary for a full and accurate description.

This weakness in the reasonable-unreasonable mistake language has a devastating effect on the interpretation of criminal statutes, as most codes, even modern codes, still use this language. Such delegation of legislative decisionmaking is a typical flaw of offense analysis;

220. Id. $\$ 2.02(2)(\mathrm{d})$. See notes 77-80 supra and accompanying text.

221. See, eg., Model Penal Code $\$ 213.6(1)$ (1980) (when criminality of conduct depends on a child's being below the age of ten, "it is no defense that the actor did not know the child's age, or reasonably believed the child to be older. . . [otherwise] it is a defense for the actor to prove that he reasonably believed the child to be above the critical age" (emphasis added)); id. $\S 223.9$ (if the actor "reasonably believed that the owner would have consented" to his use of an automobile, the actor may establish a defense to unauthorized use); accord, e.g., N.J. STAT. ANN. § 2C:20-10(a) (West 1982); see also id. § 2C:14-5(c) (reasonable mistake as to a critical age never a defense to a sexual offense). 
the courts must decide whether a provision that allows an "unreasonable mistake" as a defense permits both reckless and negligent mistakes as a defense, or only negligent mistakes. The same problem arises when a provision describing a defense requires that an actor have a particular "belief," whether reasonable or unreasonable, in an exculpatory circumstance or result. Will an actor's belief that there is a substantial risk that the element exists-i.e., a reckless mistakeprovide a defense? Not surprisingly, courts, and even code commentators, have interpreted the language both ways. ${ }^{222}$ The preferable view is that only special circumstances justify admitting a reckless mistake as a defense. ${ }^{223}$ For the same reasons that recklessness is con-

222. Culpability as to falsity in perjury offenses is often described in terms of the defendant's "belief." See, eg., Hawall REV. STAT. \$§ 710-1060 to -1063 (1976); ME. REv. STAT. ant's "belief." ANN. tit. 17-A, $\$ 452$ (1) (A) (1982); N.J. STAT. ANN. $\$ \$ 2 C: 28-1$ to -3 (West 1982); N.Y. PENAL LAW $\$ 210.00$ (5) (McKinney 1975). Under these statutes, a defendant commits a false swearing offense if he makes a false statement that he does not believe to be true. Courts and commentators have not been successful in identifying the type of mistake as to truth that will negate this culpability requirement. The Hawaii commentary, for example, is inconsistent. It states that an inadvertent falsity will not suffice but that a "reckless disregard" for the truth of the statement will. Hawall REv. STAT. $\$ \$ 701-1060$ to -1063 commentary at $434-35$ (1976). From this it would appear that an unreasonable-negligent mistake, but not an unreasonable-reckless mistake, will be a defense. On the other hand, the Hawaii commentary also states that once a lack of belief is established, there is no further need to inquire into culpability. Id. at 435. This standard suggests that even a reckless disregard, or an unreasonablereckless mistake, will be a defense if there is a belief in truth. The Model Penal Code commentary suggests that a reckless mistake will excuse. It states that liability "require[s] more than recklessness." The defendant will not be liable if he believes that what he says is true, even though he is aware of the possibility that he might be wrong. MODEl. Penal CodE $\$ 241.1$ comment 3, at 114-15 (1980). The Maine Supreme Court has reverted to pre-Code language in an attempt to articulate the culpability reflected by the term "belief" and has construed the term to require a willfully and corruptly false statement. Shorette v. State, 402 A.2d 450, 454 (Me. 1979). This construction would appear to allow any mistake, even a reckless one, as a defense. New York courts have construed the language to require intention and apparently allow any mistake as a defense. See People v. Rosano, 69 A.D.2d 643, 659, 419 N.Y.S.2d 543, 552 (App. Div. 1979), affd, 50 N.Y.2d 1013, 409 N.E.2d 1357, 431 N.Y.S.2d $683(1980)$. This construction may be explained by the fact that New York defines false swearing as intentionally mating a statement that one does not believe to be true. N.Y. PENAL LAW $\S 210.005$ (McKinney 1975). Note that where a code defines reasonable belief, use of that term, as opposed to either belief or unreasonable belief, is not ambiguous; negligence suffices to establish liability. See, e.g., MOdel Penal CoDE $\S 1.13$ (16) (Proposed Official Draft 1962) (a reasonable belief is one that is neither recklessly nor negligently held); accord, e.g., N.J. STAT. ANN. § 2C:1-14(j) (West 1982).

223. For example, where theft of lost property is proscribed, the Model Penal Code requires knowledge as to the circumstance element "lost." See Model Penal Code $§ 223.5$ (1980). Where theft of services is charged, the Code requires the prosecution to prove that the defendant obtained services "which he knows are available only for compensation." Id. $\S 223.7(1)$. Where theft by unlawful taking is charged, however, the Code apparently requires the more typical culpability of "reckless." Id. \$223.2; see MODEL Penal CODE 
sidered the norm for penal liability, ${ }^{224}$ only negligent mistakes should normally provide a defense.

Analogous to the unnecessary and inadequate common law of mistake are court decisions discussing the defenses of accident and misfortune. ${ }^{225}$ Indeed, several jurisdictions have codified a defense for an actor who commits an offense "through misfortune or by accident, when it appears that there was no evil design, intention, or culpable negligence." ${ }^{226}$ A number of other states have a similar defense provision applicable only to homicide. ${ }^{227}$ While these provi-

$\$ 2.02(3)$ (Proposed Official Draft 1962) (recklessness is the prescribed culpability when none is specified).

224. See notes 60-61, 87 supra and accompanying texts.

225. See, e.g., State v. Hofford, 152 N.J. Super. 283, 377 \.2d 962 (Super. Ct. Law Div. 1978). In Hofford, the defendant-parents, charged with cruelty, argued that the trial judge erred in refusing to instruct the jury that in order to return a guilty verdict, it must find that the defendants intended to injure their children or to cause pain when they gave the children a controlled dangerous substance. Id. at 292-93, 377 A.2d at 967 . The trial judge had denied defendants' motion for a new trial, concluding that the instruction was proper. He reasoned that the state was merely required to show an "intentional, nonaccidental act that resulted in pain and suffering." Id. at 297,377 A.2d at 969 . The trial judge relied on State v. Burden, 126 N.J. Super. 424, 426-27, 315 A.2d 43, 44-45 (Super. Ct. App. Div.), certif. denied, 65 N.J. 282, 321 A.2d 243 (1974). In Burden, the court held that the word " 'willfully' in the context of [the child neglect statute] means intentionally or purposely as distinguished from inadvertently or accidentally. [The prosecution need not prove] that defendant acted with an evil intent and knew that harm would result." Id. at 427,315 A.2d at 45 . Both the Burden and Hofford opinions address the issue of culpability in terms of accident, and it was this methodology that obscured the real issue-the culpability required as to causing the resulting harm to the child. Both decisions are inadequate because neither gives notice of what constitutes a nonaccidental injury. Indeed, although the trial judge in Hofford refers to "nonaccidental acts," it is unclear whether an act can ever be "accidental." Only results are generally described as accidental. A person "intentionally" or "knowingly" moves his arms, but "accidentally" harms his child in the process. Perhaps for this reason, most modern codes do not define recklessness and negligence with respect to conduct. See, e.g., MOdEL PENal CodE $\S 2.02(2)(c)-(d)$ (Proposed Official Draft 1962). See notes 144-54 supra and accompanying text.

226. Cal. Penal Code $\S 26(5)$ (West Supp. 1983); Nev. Rev. Stat. § 194.010(7) (1981); accord IDAHO CODE $\S 18-201$ (3) (1979). GA. CODE ANN. $\S 16-2-2$ (1982) uses slightly different language, referring to "misfortune or accident where it satisfactorily appears there was no criminal scheme undertaking, or intention, or criminal negligence." See DeBerry v. State, $241 \mathrm{Ga}$. 204, 243 S.E.2d 864 (1978) (instruction on accident or misfortune should have been given where defendant alleged that bullet struck victims by accident although deliberately fired). Arizona has recently repealed a similar statute. See ARIZ. REV. STAt. ANN. § 13$134(3)$ (current version at $\S 13-204$ (1978) (accident defense apparently treated as any other mistake that negates an offense element)).

227. These defenses are usually labelled "excusable homicide" and commonly have a variety of other limitations-e.g., the act must be lawful and done by lawful means with ordinary care or done in the heat of passion, upon sudden combat, and without a dangerous weapon. See, e.g., Fla. STAT. ANN. $\$ 782.03$ (West 1976); Miss. Code ANN. § 97-3-17 (1972); Nev. Rev. Stat. \$200.180(1) (1979); N.M. Stat. AnN. § 30-2-5 (1978); Okla. Stat. AnN. tit. $21, \S 731$ (West 1958); S.C. Code ANN. $\$ 16-3-40(1)$, (3) (Law. Co-op. 1976); S.D. Cod- 
sions have historical significance, ${ }^{228}$ they now unnecessarily reiterate, in a defense format, the culpability requirements as to result elements of offenses. To say that a nonnegligent accident that causes a prohibited result provides a defense is simply to say that all offenses containing result elements require at least negligence as to causing the prohibited result. The culpability requirements of specific offense definitions and, in some cases, general provisions, already state such requirements of culpability as to result elements. ${ }^{229}$

Such accident or misfortune defenses are apparently designed to fill a gap created because the mistake defense does not clearly encompass all of the objective elements. "Mistake" and "ignorance," as commonly understood, describe the absence of a particular state of mind as to a circumstance element, but not as to a conduct or result element. One makes a "mistake" as to another's age or property, the obscene nature of a publication, or other circumstance elements, but one "accidentally" injures another, pollutes a stream, or interferes with a law enforcement officer. As the previous discussion demonstrates, the mistake defense provisions and the accident provisions are both unnecessary. An offense's culpability requirements alone are adequate to determine precisely the mistakes or accidents that will provide a defense. ${ }^{230}$

\section{Element Analysis in Complicity}

The most important source of criminal liability, excluding the offense definition, is the complicity liability provision, which determines when an actor will be held liable for the conduct of another. Model Penal Code section 2.06 provides two distinct forms of such

Fied LaWS ANN. § 22-16-30 (1979); Vr. Stat. AnN. tit. 14, §926 (1964); Wash. Rev. Code ANN. § 9A.16.030 (Supp. 1981); see also Sargent v. State, 518 S.W.2d 807 (Tex. Crim. App. 1975) (discussing lawful act limitation). Texas no longer employs this defense because it has adopted a modern culpability scheme.

228. See 1 M. Hale, History of the Pleas of the Crown 38 (London 1736) (an act done per infortunium is not punishable by death because will and intention as well as an act are required); 3 J.F. STEPHEN, supra note 22 , at 15-16 (describing excusable homicide as including accidental homicide).

229. Sec Chart II supra. Court decisions often contrast accident with culpability requirements. See, e.g., People v. Eveland, 81 IIl. App. 3d 97, 400 N.E.2d 1078 (1980) (death of child was not accidental but was foreseeable result of reckless act); People v. Schwartz, 64 Ill. App. 3d 989, 382 N.E.2d 59 (1978) (trier of fact must determine whether killing was by misadventure or reckless conduct); People v. Morrin, 31 Mich. App. 301, 187 N.W.2d 434 (1971) (excusable homicide because death was accidental and not criminally negligent).

230. See Model Penal Code $\S 2.04$ (1) comment 1 , at 135-36 (Tent. Draft No. 4, 1955) ("ignorance or mistake has only evidential import; it is significant whenever it is logically relevant and it may be relevant to negate the required mode of culpability"). 
liability. ${ }^{231}$ Liability under section $2.06(2)$ (a) applies where the actor's confederate is innocent or irresponsible; this may be termed "causing crime by an innocent." Liability under section 2.06(3)(a)(ii) represents the traditional form of accomplice liability.

Element analysis, that is, an attempt to determine all required elements for liability precisely, reveals that these provisions are hopelessly ambiguous in many respects and that they fail to answer important liability questions that arise in complicity situations. The objective elements for causing crime by an innocent are relatively straightforward. ${ }^{232}$ The defendant need not satisfy the objective elements of the substantive offense; the point of the provision is to hold him legally accountable when he engages in conduct that causes an innocent or irresponsible person to satisfy the objective requirements. The only significant ambiguity here is that section $2.06(2)$ (a) requires that the defendant cause another to "engage in such conduct" and thus does not expressly require that the conduct that the defendant causes another to engage in be the conduct constituting the offense, that is, the conduct under the circumstances and causing the results proscribed by the offense definition. There is no doubt, however, that the drafters intended to require this. ${ }^{233}$

231. Section 2.06 provides that:

(2) A person is legally accountable for the conduct of another person when:

(a) acting with the kind of culpability that is sufficient for the commission of the offense, he causes an innocent or irresponsible person to engage in such conduct; or

....

(c) he is an accomplice of such other person in the commission of the offense

(3) A person is an accomplice of another person in the commission of an offense if:

(a) with the purpose of promoting or facilitating the commission of the offense, he

(ii) aids or agrees or attempts to aid such other person in planning or committing it . .

Model Penal Code $\$ 2.06(2)$-(3) (Proposed Official Draft 1962). Appendix.

232. A summary of the following discussion appears in Boxes 4, 5, and 6 of Chart III,

233. The commentary to this section supports this view. The defendant is accountable for the conduct of an innocent or irresponsible person when the defendant caused the conduct to occur and has the required culpability for the crime charged. "[T]he draft proposes to determine liability by the culpability and state of mind of the defendant, coupled with the overt behavior he has caused another to perform." MODEL PENAL CODE $\$ 2.04$ (2) (a) (currently $\S 2.06(2)(a))$ comment at 18 (Tent. Draft No. 1, 1953). The commentary suggests a number of hypothetical situations that illustrate this point: One who recklessly leaves his car keys with an irresponsible individual, who is known for bad driving, should be liable for homicide if the irresponsible person uses the car and kills someone; an aggressor who provokes a victim to shoot in reasonable self-defense ought to be held liable for the death of an innocent bystander. Id. at 17 . Section 2.06 (1) also supports this view by explicitly stating that 
The culpability requirements for causing crime by an innocent are somewhat more elusive. The provision states that the defendant must act "with the kind of culpability that is sufficient for the commission of the offense."234 This requirement may well rely upon offense analysis and intend to refer to a single level of culpability, as the Code does elsewhere. ${ }^{235}$ But the language also supports an element analysis interpretation. For example, under the quoted language, an actor's causing-crime-by-an-innocent liability for homicide can be said to depend upon whether he satisfies the culpability requirements of the homicide offense. Thus, if a doctor causes an operating room nurse to undertake a procedure that will result in the death of a fetus, the doctor would not be liable unless he is at least reckless as to the fetus' status as a "human being." ${ }^{236}$ In addition, the degree of his liability would depend upon his culpability as to the result element of the substantive offense-causing the death. He would be liable for murder if he intends or knows that the procedure will cause the death, and for manslaughter if he is aware of a substantial and unjustified risk that the procedure will cause the death. ${ }^{237}$

In addition to the culpability requirements of the substantive offense, liability for causing crime by an innocent requires culpability as to causing the innocent's conduct. This is a distinct issue of fact. One may knowingly cause an innocent to engage in conduct that creates a risk of causing a prohibited result or one may engage in conduct that creates a risk of causing an innocent to engage in conduct that one knows will cause a prohibited result. For example, a surgeon may order a procedure that he knows creates an unjustifiable risk to the fetus' life. Alternatively, he may scribble an order, intending to create a risk that the order will be mistakenly interpreted as requir-

\footnotetext{
"[a] person is guilty of an offense if it [(the offense)] is committed by . . the conduct of another person for which he is legally accountable... ." MODEL PENAL CODE $\S 2.06(1)$ (Proposed Official Draft 1962) (emphasis added).

234. Model Penal Code $\$ 2.06(2)$ (a) (Proposed Official Draft 1962). Box 2 of Chart III, Appendix, reflects this requirement.

235. See notes 173-75 supra and accompanying text.

236. See Model Penal Code $\$ 2.02(3)$ (Proposed Official Draft 1962). For a discussion of the application of this section, see notes $84-87$ supra and accompanying text. One might argue that if the defendant were charged with negligent homicide under MODEL PENAL CODE $\S 210.4$ (1980), then Model Penal Code $\S 2.02$ (4) (Proposed Official Draft 1962) would require only negligence as to the fetus' status as a human being. The conflict between $\S 2.02(3)$ and $\$ 2.02$ (4) is discussed at notes $170-82$ supra and accompanying text, and a resolution of that conflict is proposed at notes 204-09 supra and accompanying text.

237. This analysis presumes homicide statutes that are patterned after MODEL PENAL CODE $\S \S 210.1-.5(1980)$.
} 
ing a procedure that he is certain will cause the death. ${ }^{238}$

Section 2.06(2) (a) does not clearly address the issue of culpability as to causing the innocent's conduct. One might construe the section to require that the actor cause the innocent's conduct with "the kind of culpability that is sufficient for the commission of the offense." Under this construction, if one interprets that phrase to refer to a single level of culpability for the offense, ${ }^{239}$ then some central culpability requirement for the offense-e.g., purpose or knowledge for murder-might be taken to be the level of culpability required as to causing the innocent to act. But element analysis militates against a construction that would require such a speculative determination of some single culpability requirement for each offense. ${ }^{240}$ An element analysis construction of this section may lead to the conclusion that because no culpability term is stated, the applicable general provision, section 2.02(3), requires recklessness as to this result-causing the conduct. ${ }^{241}$ Judicial decisions rarely address this issue; where they do, they suggest, albeit indirectly, that recklessness in causing the innocent to act is sufficient. ${ }^{242}$

The final culpability issue is whether the actual perpetrator must satisfy the culpability requirements of the substantive offense in order for the defendant to be held liable for the offense. The answer seems

238. Compare People v. Marshall, 362 Mich. 170, 106 N.W.2d 842 (1961) (defendant lent his car to another knowing that the other was drunk-i.e., he knowingly caused the other to engage in conduct that created a risk of the result, a fatal crash) with Regina v. Saunders, 75 Eng. Rep. 706 (1575) (defendant placed a poison apple where his daughter would be likely to eat it--i.e., he intentionally created a risk of causing conduct of another that he knew would cause her death).

239. The commentary suggests the following construction:

When crimes call for no more than recklessness or negligence for their commission, it should suffice, it is submitted, that one with such recklessness or negligence causes the required overt conduct by an innocent or irresponsible person; there is no reason for demanding that such conduct be caused purposely.

Model Penal Code $\S 2.04$ (2)(a) (currently $\$ 2.06(2)$ (a)) comment at 17 (Tent. Draft No. 1, 1953).

240. See note 176 supro and accompanying text.

241. See notes 84-87 supra and accompanying text. Box 1 of Chart III, Appendix, reflects this interpretation.

242. Cases most frequently arise under 18 U.S.C. $\$ 2(b)(1976)$. That section provides that one who "willfully causes an act to be done which if directly performed by him or another would be an offense . . is punishable." Id. The cases rarely address the issue of the culpability required as to causing the innocent's conduct-i.e., they rarely give content to the culpability term "willfully." It seems clear, however, that reckless causation would suffice. See, e.g., Pereira v. United States, 347 U.S. 1, 8-9 (1954) ("[w]here one does an act with knowledge that [the innocent's conduct] will follow in the ordinary course . . . or where such [conduct] can reasonably be foreseen, even though not actually intended, then he 'causes' " that conduct). 
to be a clear "no."243 Liability under section 2.06(2)(a) is imposed where the perpetrator is "innocent or irresponsible." 244 Thus, the defendant is liable even though the perpetrator does not satisfy the culpability requirements of the offense. ${ }^{245}$

As with causing crime by an innocent, accomplice liability does not require the defendant to satisfy the objective elements of the substantive offense. Section 2.06(3)(a)(ii), in contrast to section 2.06 (2) (a), does not require the accomplice to "cause" the offense, but requires only that he "aid or agree or attempt to aid" the perpetrator in planning or committing the offense. ${ }^{246}$

Section 2.06(3) (a) (ii) is somewhat broader than the common law rule, which apparently requires actual assistance or encouragement. At common law, an unsuccessful attempt to aid, one that was unknown to the perpetrator and that neither encouraged nor assisted him, would not support accomplice liability. ${ }^{247}$ The Model Penal Code's expansion of accomplice liability is consistent with its shift to a subjective view of criminality that bases an actor's liability primarily on his own conduct and culpability, rather than on the success or failure of the perpetrator. However, Section 2.06(3)(a)(ii) removes the need for the accomplice to make any contribution to the commission of the offense or to an attempt.

Most states have generally rejected the Code's extreme form of subjective criminality. They have, for example, refused to adopt the Code's suggestion that an attempt be punished to the same degree as the completed substantive offense. ${ }^{248}$ Although the actor's subjective

243. This is reflected in Box 3 of Chart III, Appendix.

244. MODEl Penal Code $\$ 2.06(2)$ (a) (Proposed Official Draft 1962).

245. The section does not define "innocent" or "irresponsible." See id. The commentary's illustrations suggest that the terms are meant to include those who are excused-i.e., a "child," a "madman," and a "drunk"-_and those who lack the requisite culpability-i.e., a doctor properly performing an appropriate emergency operation that results in the patient's death, and an agent "innocently" making false statements. See MODEL Penal CODE $\S 2.04(2)$ (a) (currently $\S 2.06(2)(a)$ ) comment at $17-18$ (Tent. Draft No. 1, 1953). A summary of this element analysis of Model Penal Code $\$ 2.06(2)$ (a) appears in Chart III, Appendix.

246. Model Penal Code $\S 2.06(3)$ (a)(ii) (Proposed Official Draft 1962). These conclusions are reflected in Boxes 4 and 5 of Chart IV, Appendix.

247. See, e.g., Wilcox v. Jeffrey, [1951] 1 All E.R. 464 (court found necessary encouragement in fact that defendant paid to hear the illegal performance and did not voice any opposition to it while in attendance); State ex rel. Martin v. Tally, 102 Ala. 25, 69, 15 So. 722, 738 (1894) (the assistance provided need not be a but-for cause of the result; it is enough that it render the act easier for the perpetrator, even if the result would have occurred without the aid). Courts often employ language that appears to require actual assistance. See, e.g., United States v. Jackson, 526 F.2d 1236 (5th Cir. 1976).

248. A large number of jurisdictions provide a lesser punishment for an attempt than for the completed substantive crime, where liability is not otherwise specified. The punish- 
culpability is the same when he attempts an offense as when he completes it, only by completion does he produce the actual harm or evil of the substantive offense. This completion, according to the conventional view, however irrational, adds to his personal culpability. To be consistent, these same states should-but frequently do not ${ }^{249}$ reject that portion of the Model Penal Code complicity provision that rests accomplice liability-i.e., liability for the full substantive offense-on an ineffective attempt or agreement to aid. Under the conventional view, only attempt or conspiracy liability would be appropriate in such a case. ${ }^{250}$

A similar issue arises in determining whether, in order to hold the accomplice liable under complicity liability provisions, the perpetrator must actually satisfy the objective elements of the offense definition-i.e., commit the offense. $\Lambda$ t common law, an accomplice's liability was seen as deriving from the perpetrator's. But again, the perpetrator's ultimate failure to commit the contemplated offense does not reduce the accomplice's subjective culpability. Not surprisingly then, nothing in Model Penal Code section 2.06(3) (a) expressly requires the perpetrator to have consummated the offense. Indeed, by permitting accomplice liability where the defendant only aids in

ment for attempts varies among jurisdictions, but the typical authorized punishment is about one-half of the punishment authorized for the substantive offense. See, e.g., CaL. PENaL Code $\S 664$ (West 1970); Colo. Rev. Stat. \$ 18-2-101 (1978); Criminal Code of 1961, § 8-4, ILL. ANN. STaT. ch. 38, § 8-4 (Smith-Hurd Supp. 1980-1981); OHIO REv. Code ANN. § 2923.02 (Page 1975). Some jurisdictions, however, follow the Model Penal Code approach. The jurisdictions below impose the same punishment for attempt and for the substantive offense, except as indicated in parentheses. CONN. GEN. STAT. ANN. \$53a-49 (West 1972) (class A felony reduced to class B); DEL. CODE ANN. tit. 11, § 531 (1979); HawaII Rev. STAT. $\$ 705-$ 502 (1976); Miss. CODE ANN. $\$ 97-3-7$ (1972) (attempted capital offense punishable by maximum of ten years imprisonment); MONT. CoDe ANN. $\$$ 45-4-103 (1981); N.H. REv. STAT. ANN. $\$ 629.1$ (1974) (attempt to commit murder reduced to class A felony); N.J. STAT. ANN. $\S 2 \mathrm{C}: 5-4$ (West 1982) (attempt to commit a crime of first degree is crime of second degree); N.D. CENT. CODE $\S 12.1-06-01$ (1976) (mitigation under special circumstances); 18 PA. Cons. STAT. ANN. $\$ 901$ (Purdon 1973); WYo. STAT. \$ 6-1-204 (Supp. 1982)

249. See, e.g., ARIz. Rev. Stat. ANn. $§ 13-303(B)$ (2) (1978 \& Supp. 1982-1983); KY. Rev. STat. § 502.020(1)(b) (1975); ME. REv. Stat. AnN. tit. 17-A, §57(3)(A) (1983); Mo AnN. Stat. $\$ 562.041$ (2) (Vernon 1979); Tex. Penal Code AnN. $\S 7.02$ (a)(2) (Vernon 1974).

250. It is unclear why a jurisdiction that imposes only attempt liability for actual assistance of an incomplete crime, see, e.g., N.J. STAT. ANN. \& 2C:5-1(c) (West 1982), would impose liability for the substantive offense where the crime is completed by the perpetrator, but the aider has only attempted to aid in its completion. See id. $\S 2 \mathrm{C}: 2-6$ (c)(1)(b). This is a particularly troublesome result where the attempt and substantive offenses are punished differently. See id. $\S 2$ C:5-4(a) (attempt to commit a crime of the first degree is a crime of the second
degree). 
"planning or committing" the offense, ${ }^{251}$ the provision seems to reject such a consummation requirement. However, Model Penal Code section 2.06(7) directly contradicts this interpretation:

An accomplice may be convicted on proof of the commission of the offense and of his complicity therein, though the person claimed to have committed the offense has not been prosecuted or convicted or has been convicted of a different offense or degree of offense or has an immunity to prosecution or conviction or has been acquitted. ${ }^{252}$

In the tradition of subjective criminality, this provision generally rejects any defense for the accomplice that is premised upon a defense of the perpetrator. ${ }^{253}$ Section 2.06(7) appears to retain a narrow exception, however, when it requires, in the language italicized, that the offense have been committed. This exception may be inconsistent with the Model Penal Code's own extreme imposition of the same punishment for an attempt as for the completed offense, ${ }^{254}$ but it accurately reflects the consensus of modern codes. ${ }^{255}$

As with causing crime by an innocent, the culpability requirements for accomplice liability are somewhat more obscure than the objective requirements. Apparently, the culpability requirement that the accomplice aid the perpetrator "with the purpose of promoting or facilitating the commission of the offense" 256 accompanies the objective element of aiding in the commission of the offense. ${ }^{257}$ Thus, the accomplice escapes liability if he is merely aware of a substantial risk or even is practically certain that he is aiding the perpetrator in the offense; accomplice liability under the Code requires that the assistance be his conscious object. ${ }^{258}$

251. Model Penal Code $\S 2.06(3)$ (a)(ii) (Proposed Official Draft 1962) (emphasis added).

252. Model Penal Code $\$ 2.06$ (7) (Proposed Official Draft 1962) (emphasis added).

253. For a complete discussion of such unconvictable confederate defenses and the modern trend toward their rejection, see 1 P. Robinson, CRIMinal LaW Defenses $\$ 82$ (1983) (forthcoming).

254. See note 248 supra and accompanying text.

255. Box 6 of Chart IV, Appendix, reflects this exception.

256. Model Penal Code $\$ 2.06(3)$ (a) (Proposed Official Draft 1962).

257. One could be even more precise by distinguishing the accomplice's culpability as to his conduct, generally not an issue, from his culpability as to whether his conduct will assist the perpetrator in committing the offense, the primary issue here.

The verb "aids," like those discussed at notes 128-33 supra and accompanying text, actually combines conduct and result elements; the actor must engage in conduct that provides aid. The significant culpability here is culpability as to that result. The Model Penal Code, for example, requires "the purpose of promoting or facilitating . . . ." MODEL PENAL CODE $\S 2.06$ (3) (a) (Proposed Official Draft 1962). Culpability as to the conduct itself is, as in most cases, generally insignificant. See notes $183-87,195-98$ supra and accompanying text.

258. "The draft [in $\S 2.06(3)(a)]$ confines the scope of liability to crimes that the accom- 
Whether purpose should be required or knowledge should suffice as the level of culpability as to aiding the perpetrator has been a matter of considerable dispute. ${ }^{259}$ Although most states have followed the Model Penal Code's lead and required purpose, ${ }^{260}$ many states have created an additional offense of criminal facilitation that imposes reduced punishment for knowing assistance of a substantive offense. ${ }^{261}$

The greatest flaw in the Model Penal Code provision, and those provisions modeled after it, is their failure to specify all of the culpability requirements of the substantive offense that the accomplice must satisfy. ${ }^{262}$ While a separate subsection of section 2.06 explains

plice had the purpose of promoting or facilitating." MODEL PENAL CODE $\$ 2.04$ (currently $\S 2.06$ ) comment 2, at 24 (Tent. Draft No. 1, 1953) (section 2.06(3)(b), which was deleted prior to the adoption of the Proposed Official Draft, see note 259 infa, provided liability for substantial facilitation provided with knowledge). Courts have construed statutes patterned after Model Penal Code $\S 2.06$ (3)(a) (Proposed Official Draft 1962) to require an intention to promote the crime. See, e.g., Leasure v. State, 385 A.2d 730, 732 \& n.2 (Del. 1978) (DeL. CODE ANN. tit. 11, § 271(2)(b) (1979) requires proof that defendant aided with the intent to promote or facilitate the commission of the offense; held trial judge's omission of the definition of intention in the context of the aiding and abetting charge was reversible error); State v. Yabusaki, 58 Hawaii 404, 408, 570 P.2d 844, 847 (1977) (evidence sufficient to establish the conscious object to promote or facilitate the burglary, as required by HAWAII REV. STAT. $\S 702-222$ (1976)); People v. Mickel, 73 III. App. 3d 16, 20, 391 N.E.2d 558, 562 (1979) (Criminal Code of 1961, § 5-2(c), ILL. ANN. STAT. ch. 38, § 5-2(c) (Smith-Hurd 1972) "requires that defendant act with the intent to promote or facilitate" the crime); Morrison v. State, 608 S.W.2d 233, 235 (Tex. Crim. App. 1980) (evidence was insufficient to show that defendant committed "some act with intent to promote or assist the commission of the offense," as required by Tex. Penal Code ANN. $\$ 7.02(a)(2)$ (Vernon 1974))

259. In the tentative draft of the Model Penal Code, the drafters suggested that accomplice liability be permitted where one knowingly provided substantial assistance. See MODEL Penal Cone $\S 2.04(3)$ (b) (Tent. Draft No. 1, 1953) (providing for accomplice liability if "acting with the knowledge that [another] person was committing or had the purpose of committing the crime, [the accomplice] knowingly, substantially facilitated its commission . . . ."). In the end, the drafters determined to require "the purpose of promoting or facilitating" for both complicity and conspiracy. See MODel Penal Code $\$ 5.03$ comment 2, at 107 (Tent. Draft No. 10, 1960). See generally id. (discussing the various interests implicated by the alternatives-purpose or knowledge).

260. See, e.g., Criminal Code of 1961, § 5-2(c), Ill. Stat. AnN. ch. 38, § 5-2(c) (SmithHurd 1972); N.J. Stat. AnN. $\$ 2$ C:2-6(c)(1) (West 1982); N.Y. Penal Law $\$ 20.00$ (McKinney 1975); 18 Pa. Cons. Stat. AnN. $\$ 306$ (Purdon 1973). Conira Ind. Code ANN. \$ 35-41-24 (West 1978); Mich. Comp. Laws ANN. $\$ 415$ (West 1968). Box 1 of Chart IV, Appendix, reflects the majority view requiring purposeful aid of the perpetrator.

261. See, e.g., ARIz. Rev. Stat. Ann. § 13-1004 (Supp. 1982-1983); N.Y. Penal LaW $\S \S 115.00, .01, .05, .08$ (McKinney Supp. 1982-1983).

262. At least one jurisdiction has so specified. See N.Y. PENAL LAW $\$ 20.00$ (McKinney 1975). That statute provides: "When one person engages in conduct which constitutes an offense, another person is criminally liable for such conduct when, acting with the mental culpability required for the commission thereof, he solicits, requests, commands, importunes, or intentionally aids such person to engage in such conduct." Id. But of. id. $\S 115.10$ (it is not 
that the accomplice must satisfy the culpability as to the result element that is required by the substantive offense, ${ }^{263}$ no analogous provision explains the culpability required for the circumstance elements of the substantive offense. For example, assume that the defendant purposely aids another to seduce a female. The offense of seduction frequently requires that the female be under 16 and that the actor be at least negligent as to that circumstance element (her being under 16). ${ }^{264}$ To be held as an accomplice to the seduction, what culpability as to the circumstance of age must be shown?

One might argue that purposefulness as to the age of the female must be shown, on the theory that such is implicit in the requirement that the defendant aid the perpetrator "with the purpose of promoting or facilitating the commission of the offense." 265 But that language was probably not intended to apply the purposeful requirement beyond the objective conduct and result elements contained in "aiding."266 For example, the existence of a special provision that

a defense to facilitation that defendant did not act with the culpable mental state required for the commission of the offense facilitated).

263. Section 2.06(4) provides that:

[W] hen causing a particular result is an element of the offense, an accomplice in the conduct causing such result is an accomplice in the commission of that offense, if he acts with the kind of culpability, if any, with respect to that result that is sufficient for the commission of the offense.

Model Penal Code $\S 2.06$ (4) (Proposed Official Draft 1962). This requirement is expressed in Box 2 of Chart IV, Appendix.

Note that by using the term "accomplice," this provision only applies to accomplice liability under $\S 2.06(2)(c)$ and $\S 2.06(3)$. It does not apply to one who is accountable for the conduct of another, under $\S 2.06(2)(a)$, because he has caused a crime by an innocent. For a construction of $\S 2.06(2)$ (a) that would require the culpability as to a result specified by the substantive offense, see notes $234-37$ supra and accompanying text.

264. See, e.g., Model Penal Code $\S \S 213.3(1)(a), .6(1)$ (1980).

265. Model Penal Code $\S 2.06(3)$ (a) (Proposed Official Draft 1962) (emphasis added). This provision is discussed at text accompanying notes 256-61 supra. For cases holding that the purpose must encompass all elements of the substantive offense, see note 268 infra.

266. See notes 256-61 supra and accompanying text. The commentary suggests that the purpose requirement was limited to culpability as to providing assistance. In discussing the provision that requires the accomplice to entertain the culpability with respect to the result that is required by the substantive offense, see text accompanying note 263 supra, the commentary states that: "This formulation serves, it is submitted, to combine the policy that accomplices are equally accountable within the range of their complicity with the policies embodied in the definitions of particular crimes." MODEL PENAL CODE $\$ 2.04$ (4) (currently $\S 2.06(4)$ ) comment at 34 (Tent. Draft No. 1, 1953) (emphasis added). In addition, the commentary, in explaining the phrase "purpose to promote or facilitate" in the context of conspiracy, addresses the impact of that phrase on the actor's culpability as to the circumstance elements of the substantive crime promoted. It concludes that "as in the Section on complicity," the draft "does not attempt to solve the problem by explicit formulation . . . ." MODEL PENal CODE $\S 5.03$ comment 2, at 113 (Tent. Draft No. 10,1960). Further, the commentary does not suggest an intent to change prior law governing the accomplice's culpability as to the substan- 
requires satisfaction of the culpability requirement as to a result element of the offense definition suggests that the purpose requirement does not apply to all of the elements of the substantive offense. Moreover, a requirement of purpose as to all circumstance elements would require a higher level of culpability as to circumstances for the accomplice than for the perpetrator. Such a requirement would bar accomplice liability in the hypothetical above unless the accomplice was aware of a high probability that the female was under $16 ;{ }^{267}$ it could well require that the accomplice's interest in aiding depend in part on the girl's youth. As a policy matter, no interest justifies such a standard for accomplice liability. ${ }^{268}$

tive offense. Prior law did not clearly require a demonstration of purpose as to each element of the substantive offense in order to establish accomplice liability. For a discussion of relevant cases, see note 272 infra. Typically, the commentary indicates when a particular proposal will affect a change. See, e.g., MODEL Penal CoDE $\$ 2.04$ (currently $\$ 2.06$ ) comment 3 at 27 (Tent. Draft No. 1, 1953) (liability for attempt to aid goes in part beyond present law). Where a jurisdiction does not define "purposeful" as to circumstances, see note 66 supra, it follows that the purpose requirement can not be construed to extend to circumstance elements.

267. The Model Penal Code defines "purposely" with respect to a circumstance element as awareness of the existence of or a belief or hope that the circumstance exists. MODEL Penal CODE $\$ 2.02(2)$ (a)(ii) (Proposed Official Draft 1962). Thus, under this definition, purpose is satisfied by demonstrating knowledge of the existence of the circumstance. See id. $\S 2.02$ (2)(b)(i) (defining knowledge with respect to circumstances as awareness of existence).

268. As the commentary states in the context of proof of intention to promote or facilitate the commission of the crime that is the object of a conspiracy, "We think it strongly arguable that such a purpose may be proved although the actor did not know of the existence of a circumstance which does exist in fact, when knowledge of the circumstance is not required for the substantive offense." MODEL Penal CODE $\$ 5.03$ comment 2, at 113 (Tent. Draft No. 10, 1960) (emphasis added).

While courts have rarely addressed this issue, where jurisdictions have interpreted complicity statutes patterned after Model Penal Code $\S 2.06(3)$ (a), they have often required purpose as to each element of the substantive offense. The opinions have done so without offering theoretical support for the requirement. In People v. Mickel, 73 Ill. App. 3d 16, 391 N.E.2d 558 (1979), for example, the court, after noting that Criminal Code of 1961, \$5-2(c) ILL. ANN. STAT. ch. 38, § 5-2(c) (Smith-Hurd 1972) requires an intent to promote or facilitate the offense one aids, held that this intention requirement precluded liability for aiding any homicide other than intentional homicide and implicitly held that the accomplice must act intentionally as to each offense element. The court's holding was based, then, merely on the language of the statute. For an Illinois appellate case reaching a different conclusion, see note 272 infra. More typically, courts do not address the issue of culpability as to the elements of the substantive offense. See, e.g., State v. White, 622 S.W.2d 939, 945 (Mo. 1981) (defendant must aid with the conscious object of causing the offense; rejecting defendant's contention that prosecution was required to establish the culpability for murder in a charge of murder based on complicity and holding that the prosecution must establish only a conscious object to cause the offense); Commonwealth v. Henderson, $249 \mathrm{~Pa}$. Super. 472, 482, 378 A.2d 393, 398 (1977) (defendant must share the intent to commit the offense); Morrison v. State, 608 S.W.2d 233, 234 (Tex. Crim. App. 1980) (defendant must have the intent to promote or
assist). 
An alternative argument is that, because the accomplice provision specifies no culpability level with respect to circumstance elements of the substantive offense, section 2.02(3)-the general gapfilling provision-supplies a requirement of recklessness. Thus, in the seduction hypothetical above, the accomplice would have to be reckless, a slightly higher culpability level than the negligence required for the perpetrator. Recklessness, at least, is the norm for minimum culpability. In the seduction example, this approach is, therefore, somewhat more defensible as a policy matter. On the other hand, where the substantive offense requires purpose or knowledge as to a circumstance, ${ }^{269}$ this view would permit accomplice liability upon proof of a lower culpability than that required by the substantive offense for the perpetrator. Such a result seems inappropriate.

A third approach, and the most appealing and logical of the three, would treat circumstance elements no differently than result elements and requires for both the same levels of culpability for accomplice liability as those required by the substantive offense definition. This third approach seems to be compelled by the fact that the degree of liability for many crimes varies with an actor's level of culpability as to a circumstance. ${ }^{270}$ To impose accomplice liability using any other formula would ignore such statutorily demanded liability distinctions. ${ }^{271}$ Unfortunately, although there is some case

269. See, e.g., N.J. STAT. ANN. $\$ 2$ C:20-6 (West 1982) (theft of lost property requires knowledge of the fact that the property is lost); MOdel Penal Code $\S 213.1$ (2)(b) (1980) (knowledge of a victim's mental defect is an element of one form of gross sexual imposition).

270. For example, the offense of burglary under the Model Penal Code is typically a felony of the third degree. If, however, the offense is perpetrated in the dwelling of another at night, it is a felony of the second degree. MOdel Penal CODE $\$ 221.1(1)-(2)$ (1980). The actor must be reckless as to the aggravating circumstances. See MODEL Penal Code \$2.02(3) (Proposed Official Draft 1962); notes 84-87 supra and accompanying text. Thus, the degree of liability is affected by the degree of culpability as to the circumstances of "dwelling" and "at night." Similarly, one's liability for one form of gross sexual imposition depends on whether the defendant knows that the woman suffers from a mental disease or a defect that renders her incapable of appraising her conduct. See MODEl PeNal CODE $\$ 213.1(2)(\mathrm{b})$ (1980). Assuming that no other offense is committed, an actor who did not know of this defect would not be liable.

271. To continue with the burglary example, see note 270 supra, requiring that the accomplice be purposeful as to all circumstance elements would defeat the legislature's distinctions with respect to the circumstance elements "dwelling" and "at night." The accomplice who is reckless as to the building's status as a dwelling may only be punished for a felony of the third degree, and he receives this punishment despite a legislative decision to impose a greater punishment under such circumstances. See note 270 supra. Similarly, in the gross sexual imposition example, see note 270 supra, applying Model Penal Code $\$ 2.02(3)$ to require only recklessness as to each element of the substantive offense may result in the conviction of a defendant who is only reckless as to a woman's mental defect for aiding in the 
law and statutory precedent, ${ }^{272}$ no language in section 2.06 supports this view. ${ }^{273}$ Nonetheless, given the difficulties inherent in each of the alternatives, this view is the only acceptable position for defining accomplice liability. 274

As seems clear from the broad language of section 2.06(7) quoted earlier, ${ }^{275}$ even if the perpetrator does not satisfy the culpability requirements of the offense definition, the accomplice may still be liable. $^{276}$ As noted previously, this provision reflects the core of subjective criminality, under which the defendant's liability for an offense is properly based on his own conduct of assistance and his own culpability, regardless of the perpetrator's culpability or lack thereof. ${ }^{277}$

commission of the offense of gross sexual imposition, even though the legislature has proscribed sexual penetration only when one knows of the victim's mental defect.

This objection applies equally to any fixed culpability level to be required as to all circumstance elements. This article has discussed statutory construction that would read in purpose or recklessness requirements as to circumstances. See notes 264-70 supra and accompanying text. A knowing standard also has been suggested by some case law. See, e.g., United States v. Crow Dog, 399 F. Supp. 228, 242 (N.D. Iowa 1975) (accomplice must have knowledge of the crime and intend its commission), affd, 532 F.2d 1182 ( 8 th Cir. 1976), cert. denied, 430 U.S. 929 (1977); Baldrige v. State, 543 S.W.2d 639, 643 (Tex. Crim. App. 1976) (knowledge of perpetrator's intent to kill is essential to a charge of aiding and abetting murder with malice).

272. See, e.g., United States v. Adreen, 628 F.2d 1236, 1245 (9th Cir. 1980) (accomplice must act "willfully and with the specific intent required for the commission of the particular crime"); United States v. Short, 493 F.2d 1170, 1172 (9th Cir.) (proof of complicity in armed robbery must encompass same elements as would be required to convict the principal as well as intention to aid), cert. denied, 419 U.S. 1000 (1974); United States v. Corbin Farm Serv., 444 F. Supp. 510, 525 (E.D. Cal.) (government "must show the same extent of knowledge on the part of [the] aider and abetter as it must show to obtain a conviction as a principal'), aff'd, 578 F.2d 259 (9th Cir. 1978); People v. Comer, 78 Ill. App. 3d 914, 916, 397 N.E. 2d 929, 931 (1979) (must prove aid with intent to promote and each element of the substantive offense); State v. Thomas, 66 A.D.2d 1001, 1001, 412 N.Y.S.2d 68, 70 (App. Div. 1978) (applying New York statute quoted at note 262 supra and requiring for complicity the culpability required for the substantive offense); N.Y. PENaL LAw $\$ 20.00$ (McKinney 1975) (requiring the same mental culpability for complicity as required for the commission of the offense).

273. The Code may fail to state a position on the issue because the drafters believed that the courts would resolve the issue under the independent law of mistake. See notes 210-30 supra and accompanying text. For the drafters' rationale for failing to address this issue in the context of conspiracy, see text accompanying note 321 infra.

274. This is the view stated in Box 2 of Chart IV. Appendix. Given the narrow scope of the conduct element proposed earlier, culpability as to conduct is unimportant, see notes 183-87, 195-98 supra and accompanying texts; note 257 supro, and is therefore not represented in Box 1 of Chart IV, Appendix.

275. See text accompanying note 252 supro.

276. Box 3 of Chart IV, Appendix, states this rule.

277. The defendant's culpability will depend, however, upon whether the harmful conduct or result actually occurs. If the conduct or result does not occur, only attempt liability is appropriate. See notes 251-55 supra and accompanying text. 
The following formulation would more clearly state the elements of liability for causing crime by an innocent and for complicity:

\section{Liability for the Conduct of Another}

(1) An actor is guilty of an offense if, acting with the culpability required for the commission of the offense, he:

(a) [recklessly/knowingly] causes an innocent or irresponsible person to commit the offense; or

(b) [knowingly] solicits another person to commit the offense; or

(c) [purposely/knowingly] aids another to commit the offense. ${ }^{278}$

(2) It is no defense to accomplice liability under Subsection (1) of this section that the perpetrator of the offense does not satisfy the culpability requirements of the offense definition.

(3) If the intended perpetrator does not satisfy the objective elements of the offense, an actor who would have been liable as an accomplice to the offense under subsection (1) if the perpetrator had satisfied the objective elements is guilty of an attempt to commit the offense.

\section{Element Analysis in Attempt}

An element analysis of Model Penal Code section 5.01(1),279 which defines attempt, reveals several important ambiguities and unanswered questions relevant to the section's requirements for attempt liability. An actor need not satisfy the objective elements of the substantive offense to be liable for attempt; ${ }^{280}$ the defendant must en-

278. The theoretical debate and the statutory ambiguities concerning these culpability requirements - culpability as to causing the innocent to commit the offense or aiding the principal-are discussed at texts accompanying notes $238-42,256-61$ supra. While recklessiy is currently required as to "causing" the innocent to commit the offense and purposely as to "aiding" another, see id., it is not clear that the culpabilities as to "causing" and "aiding" should be different from each other, or from that as to "soliciting." For this reason, "knowingly" has been added to the brackets as an option. As a practical matter, the importance of these culpability requirements will diminish significantly once it is required that the defendant satisfy the culpability requirements of the substantive offense.

279. Section 5.01(1) defines an attempt as follows:

A person is guilty of an attempt to commit a crime if, acting with the kind of culpability otherwise required for the commission of the crime, he:

(a) purposely engages in conduct which would constitute the crime if the attendant circumstances were as he believes them to be; or

(b) when causing a particular result is an element of the crime, does or onits to do anything with the purpose of causing or with the belief that it that it will cause such result without further conduct on his part; or

(c) purposely does or omits to do anything which, under the circumstances as he believes them to be, is an act or omission constituting a substantial step in a course of conduct planned to culminate in his commission of the crime.

Model Penal Code $\$ 5.01$ (1) (Proposed Official Draft 1962).

280. This is noted in Box 4 of Chart V, Appendix. 
gage in some conduct, but the precise conduct that constitutes an attempt depends upon the defendant's apprehension of the situation-that is, upon "the circumstances as he believes them to be." The attempt provision is the most obvious example of the Code's commitment to subjective criminality: Even the objective elements of attempt liability are defined by reference to the defendant's subjective perspective. This reliance upon the defendant's perspective assures that even impossible attempts will be punished. ${ }^{281}$

Model Penal Code section 5.01(1) gives three alternative subsections under which attempt liability can be imposed. Subsection (a) contemplates the case where, from his own mistaken view, the defendant has satisfied the objective elements of the substantive offense; subsection (b), applicable to offenses with a result element, punishes a defendant who believes he has done everything he need do to cause the prohibited result; and subsection (c) imposes liability on a defendant who believes he has taken a substantial step towards commission of the offense. ${ }^{282}$

While these provisions aptly describe three common factual situations in which attempts arise, and while they draw distinctions that are important under common law doctrines, ${ }^{283}$ they no longer represent conceptually significant distinctions. Only when one isolates and compares the objective elements for each subsection does it become apparent that the complex and confusing three-subsection structure of the Model Penal Code provision is unnecessary, at least as far as the objective elements are concerned. Specifically, because the objective elements of both subsections (a) and (b) by definition include the substantial step requirement of subsection (c), ${ }^{284}$ the sub-

281. See Model Penal Code $§ 5.01$ (1) (a) comments 4-5, at 30-38 (Tent. Draft No. 10, 1960) (discussing the rejection of the impossibility defense and impossibility generally). See generally 1 P. RobiNson, supra note $253, \S 85$ (1983); G. WILliaMS, supra note $7, \S 205$, at 633-35; Elkind, Impossibility in Criminal Attempts: A Theorist's Headache, 54 VA. L. REv. 20 (1968); Hughes, One Further Footnote on Attempting the Impossible, 42 N.Y.U. L. REV. 1005 (1967); Sayre, Criminal Attempts, 41 HARV. L. REV. 821, 848-55 (1928).

282. The objective elements of these subsections are summarized in Box 3 of Chart $V$, Appendix.

283. The three subsections of Model Penal Code $\$ 5.01$ (1) (Proposed Official Draft 1962) are analogous to the three most common examples of factual situations and the three most debated aspects of attempt liability: impossibility (subsection (a)); last proximate act (subsection (b)); and substantial step (subsection (c)). Indeed, the commentary is organized into subsections, some of which bear similar labels. See MODEL PENAL. CODE $\$ 5.01$, comments 4-5, at 32-39 (Tent. Draft No. 10, 1960).

284. At least one jurisdiction has adopted a statute that requires only the culpability required for the offense attempted and a substantial attempt towards its commission. See IND. CODE ANN. $§ 35-41-5-1$ (West 1978). 
stantial step requirement is itself enough to create liability for the situations contemplated by subsections (a) and (b). If the defendant believes he has completed the offense (subsection (a)) or has done everything he needed to do to cause the prohibited result (subsection (b)), he necessarily has intended to take a substantial step towards commission of the offense (subsection (c)). The revision of this provision proposed below employs only the substantial step requirement, which suffices alone to cover fully the other cases.

The primary culpability requirement of the Model Penal Code attempt provision is that the defendant have acted "with the kind of culpability otherwise required for commission of the crime."285 This phrase is similar to the phrase that appears in the provision imposing liability for causing crime by an innocent. ${ }^{286}$ As noted in the previous discussion of that provision, the phrase may contemplate offense analysis-that is, it may presume a single culpability level for each offense. But, as demonstrated above, the phrase is broad enough to encompass element analysis-that is, to require the particular culpability prescribed as to each of the objective elements by the substantive offense definition. The latter interpretation is particularly persuasive here since nowhere does the attempt provision adequately describe the culpability required with respect to the elements of the substantive offense. The provision does not explain, for example, whether liability for attempted seduction requires at least negligence as to whether the female is over 16 , as is required by the substantive offense. $^{287}$

In addition to the culpability requirements of the substantive offense, the Model Penal Code attempt provision expressly provides a purpose requirement. The general effect of this purpose requirement is to increase the level of culpability required by the substantive offense. Specifically, subsections (a) and (c) require that the actor "purposely engage[ ] in conduct which would constitute the crime" and "purposely do[ ] or omit[ ] to do anything which [is] a substantial step." 288 Subsection (b) does not have a similar requirement. It requires only that the actor "do[ ] or omit[ ] to do anything."289 The

285. Model Penal Gode $\S 5.01$ (1) (Proposed Official Draft 1962). This is reflected in Box 2 of Chart V, Appendix.

286. See id. $\S 2.06(2)$ (a) (Proposed Official Draft 1962); see note 231 and text accompanying notes $231-34$ supra.

287. For an illustration and discussion of such a statute in the context of complicity liability, see notes 264-69 supra and accompanying text.

288. Model Penal Code $\S 5.01$ (1)(a), (c) (Proposed Official Draft 1962).

289. Id. $\S 5.01(1)(\mathrm{b})$. The provision does contain purpose or belief language, but in 
purpose requirement is consistent with often-heard claims that attempt is an "intentional offense" or a "specific intent offense."290 A further question remains, however: As to which elements must the actor be purposeful? The answer to this question is ambiguous.

One interpretation of the "purposely" requirement is that it requires purposefulness only as to conduct. But in an ideal element analysis scheme, ${ }^{291}$ the actor's culpability solely as to his conduct has little or no significance if he is normal, and gives way to general excuse defenses if he is abnormal. ${ }^{292}$ According to another interpretation, the drafters intended that "purposely" apply to all elements, including all elements of the substantive offense. This is consistent with Model Penal Code section 2.02(4), which applies a prescribed culpability element to all elements of an offense. Under this interpretation, however, an actor would be liable for attempted seduction, for example, only if he were aware that the female was, or had a conscious desire that the female be, under 16. His clear, conscious disregard of a substantial risk that she was under 16 would be insufficient, ${ }^{293}$ although such disregard would be sufficient had the seduction been completed. This interpretation would raise every culpability requirement to purpose from the level prescribed in each

subsection (b), unlike subsections (a) and (c), this language refers only to culpability as to the result element of the offense attempted; it does not refer to culpability as to "doing" or "omitting" or "engaging in conduct," which would constitute the attempt. The purpose language in subsection (b) could not, therefore, be construed to raise the culpability as to circumstance elements of the substantive offense. Apparently the drafters omitted the purpose requirement here because they wished to impose attempt liability where the defendant believes, but does not hope, that his conduct will cause a particular result. MODEL PENAL Code $\$ 5.01$ comment 3, at 29 (Tent. Draft No. 10,1960). But this issue is relevant not to the issue of culpability as to the attempt, but rather to culpability as to the elements of the substantive offense. See text accompanying notes 299-301 infra.

290. As Perkins states, "The word 'attempt' means to try; it implies an effort to bring about a desired result. Hence, an attempt to commit any crime requires a specific intent to commit that particular offense." R. PERKINS, CRIMINal Law 637 (3d ed. 1961) (footnotes omitted); see, e.g., People v. Mitchell, 98 Ill. App. 3d 398, 424 N.E.2d 658 (1981) (attempted murder requires specific intent to commit murder; knowledge that death may result is insufficient for attempted murder); see also MODEL PENAL CoDE $\$ 5.01$ comment 3, at 27 (Tent. Draft No. 10, 1960); Dennis, The Law Commission Report on Attempt and Impossibility in Relation to Altempl, Conspiracy and Incitement: (I) The Elements of Altempl, 1980 CRIM. L. REV. 758, 761 (the Law Commission has adopted the common law position that attempt is a crime of "specific intent"); Sayre, supra note 281, at 841 ("[T] attempt without proof of a specific intent to effect some consequence which constitutes a crime.").

291. See notes 183-209 supra and accompanying text.

292. See notes $195-98$ supra and accompanying text.

293. For a discussion of this hypothetical in the context of complicity, see text accompanying notes $264-68$ supra. 
substantive offense-most frequently recklessness. Attempted burglary, for example, would require, among other things, proof that the actor was aware of, or consciously desired, the unlicensed nature of his entry or the building's status as a dwelling. ${ }^{294}$ The actor who consciously disregarded a substantial risk of these circumstances would not be liable, although such culpability would be sufficient if the burglary were completed. It is unlikely that the drafters intended this result. ${ }^{295}$ Thus, the first interpretation, which limits the requirement of purpose to the attempt conduct where the requirement has little effect, seems preferable. Subsection 5.01(1)(b) does not have a similar purpose requirement. Knowing would therefore be read in by section $2.02(3)$ as the culpability required to do or omit to do. ${ }^{296}$

My own speculation is that the "purpose" requirement is a remnant of offense analysis that owes its continuing existence to the following rationale: People ought not to be liable for conduct that is only an apparent and not an actual attempt to commit an offense. To avoid imposing this unjust liability, the drafters define attempt as a purposeful or intentional offense-that is, the actor must desire or intend to commit the offense. Thus, the drafters believe that the "purpose" requirement serves as an important safeguard for individuals who have not caused the evil or consummated the harmful conduct constituting the substantive offense. ${ }^{297}$ An element analysis of

294. See, e.g, Model Penal Code $\S 221.1(1)-(2)$ (1980). For a discussion of $\S 221.1$ (1)-(2), see notes $270-71$ supra and accompanying text.

295. The commentary states, "[T] he actor must have for his purpose to engage in the criminal conduct . . . but . . . his purpose need not encompass all the surrounding circumstances included in the formal definition of the substantive offense." MODEL. PENAL CODE $\S 5.01$ (1) comment 3, at 27 (Tent. Draft No. 10, 1960). The commentary suggests, however, that it is unclear whether this would be the result under prevailing law. See id. at 28. Language in several decisions is broad enough to give rise to the inference that some courts would require a demonstration that the actor's purpose also encompassed circumstance elements. See, e.g., People v. Hanley, 50 Ill. App. 3d 651, 659, 365 N.E.2d 676, 683 (1977) (in attempted rape case, defendant must intend to accomplish intercourse by force and against the woman's will). But see State v. Davis, 108 N.H. 158, 160-61, 229 A.2d 842, 844 (1967) (where statutory rape is charged, actor need only have intent to engage in intercourse with the woman; his ignorance of the female's age does not preclude liability for attempted rape). See generally Smith, Two Problems in Criminal Attempts, 70 HARV. L. REV. 422 (1957) (arguing that intention as to a result should be required but that the culpability as to a circumstance should be that required by the offense definition).

296. This interpretation is reflected in Box 1 of Chart V, Appendix. For a further discussion of the omission of the purpose requirement in subsection (b), see note 289 supra. follows:

297. The purpose requirement in the attempt provision is sometimes defended as

It has sometimes been argued that it is illogical that there should be a stricter requirement of mens rea in a preliminary offense than is necessary for the full offense. The Law Commission meets this point by saying that there is less justification for 
the attempt provision reveals, however, that attempt liability will not be imposed unless the actor satisfies all of the culpability requirements as to the various objective elements of the substantive offense. These requirements adequately protect against improper imposition of attempt liability and thus provide the safeguards that the drafters endeavored to achieve with the purpose requirement. ${ }^{298}$

The Model Penal Code attempt provision contains a second passage that increases the culpability requirements of the substantive offense. Subsection $5.01(1)(\mathrm{b})$, which appears to govern attempt liability for offenses with a result element, ${ }^{299}$ requires that the defendant act "with the purpose of causing or with the belief that his conduct will cause" the prohibited result. ${ }^{300}$ In effect, this raises the culpability as to any result to at least knowledge. ${ }^{301}$ Thus, attempt liability is barred for offenses normally requiring only recklessness or negligence, or imposing strict liability as to causing a result, unless the defendant was in fact knowing as to the result.

This limitation of culpability to at least knowledge implements the common law rule that one cannot be liable for an attempt to commit a "crime of recklessness." 302 Element analysis permits a

imposing strict liability (or negligence) if the defendant neither intended to do nor succeeded in completing the forbidden act. To this may be added the point that there is no evidence of a pressing social need to punish nonintentional attempts. Dennis, supra note 290, at 762 (italics and footnotes omitted).

298. There is authority for rejection of the "purpose" requirement in attempt. At least one state imposes liability for attempt where the actor satisfies the culpability requirements of the substantive offense and takes a substantial step towards its commission. See IND. CODE ANN. § 35-41-5-1 (West 1978); see also Harris v. State, — Ind. -, 425 N.E.2d 112 (1981) (construing § 35-41-5-1). An alternative explanation for the continued existence of the purpose requirement is that the "purposely" language grows out of a concern that there be no attempt liability for reckless offenses. See note 302 infra and accompanying text. But as the text immediately following explains, this is already accounted for under MODEL. PENAL CODE $\S 5.01$ (1)(b) (Proposed Official Draft 1962).

299. The commentary clearly indicates that $\$ 5.01(1)(b)$ is the subsection intended to apply where a result element crime is involved. MODEL PENAL CODE $\$ 5.01$ comment 3 , at 29-30 (Tent. Draft No. 10, 1960). The structure of $\S 5.01$, however, appears to allow a prosecutor to found liability on any one of the three subsections. While not intended by the drafters, nothing on the face of the statute would prevent the use of subsections (a) or (c) for offenses with result elements. Note that this problem does not occur under the revision proposed at the conclusion of this section. See text accompanying notes 306-08 infra.

300. This requirement is reflected in Box 1 of Chart $V$, Appendix.

301. "Belief" is the conditional form of "know," see MODEL PENAL CODE $\$ 2.02(7)$ (Proposed Official Draft 1962), and is required here because in an impossible attempt the actor cannot "know" that he will cause the result, since he in fact cannot. He can only "believe" that he can cause it. The provision has the additional purpose of imposing liability where the actor knows that a result will follow but does not desire that result. See Model Penal Code $\S 5.01$ comment 3, at 29 (Tent. Draft No. 10, 1960).

302. See, e.g., People v. Viser, 62 Ill. 2d 568, 581, 343 N.E.2d 903, 910 (1975) (there is no 
somewhat more precise definition of the scope of this exclusion from attempt liability. Driving with bald tires ("reckless driving") might be seen as a "crime of recklessness" (a classic offense analysis characterization) for which, then, attempt liability is barred. Yet reckless driving does not require recklessness as to any result element. The offense has no result element: The reckless driver need not in fact create a risk. The offense requires only conduct (driving) under a particular circumstance (with bald tires). Thus, if one were stopped in a car with bald tires just before pulling out of a driveway, liability for attempted reckless driving would not be barred by the Model Penal Code provision. Professor Glanville Williams persuasively argues for the propriety of attempt liability for such an offense. ${ }^{303}$

On the other hand, reckless homicide (manslaughter) is an offense that requires recklessness as to the result - causing death. If $X$ shoots at pigeons on the roof of a railway car, thereby risking death to the passengers, he will be liable for reckless homicide if the risk comes to fruition and he hits and kills a passenger. If, under the same circumstances, he is stopped just before he pulls the trigger, he should not be liable for attempted reckless homicide. Accordingly, subsection 5.01(1) (b) bars such liability and requires that he at least be aware (or believe) that there is a substantial certainty that his conduct will cause the death. Such knowledge, of course, makes the crime attempted murder, not attempted reckless homicide.

The Code properly bars liability for attempted reckless homicide because reckless homicide takes into account not only the risk-creating activity, but also the resulting harm. In the absence of the resulting harm, the risk-creating activity is deemed less culpable and hence carries a lower degree of liability. Reckless endangerment, which punishes pure risk-taking, is commonly a misdemeanor, while reckless homicide is a second degree felony. ${ }^{304}$ Since the degree of liability for attempt is generally proportional to the degree of liability for the substantive offense attempted, ${ }^{305}$ liability for attempted reckless homicide would improperly increase the actor's liability, based upon the presence of a harm that did not in fact occur. Liability for at-

such criminal offense as an attempt to achieve an unintended result). See generally $W$. LAFAVE \& A. SCOTT, supra note $7, \S 59$, at 429-30; Smith, supra note 295 , at 434 .

303. G. WILliaMS, supra note 7, § 199, at 619-20; see also W. LAFAVE \& A. SCOTT, supra note 7, § 59, at 429-30; J. SMITH \& B. Hogan, CRIMINal LaW 191-92 (3d ed. 1973).

304. Compare MOdel Penal CODE $\S 211.2$ (1980) (reckless endangerment is a misdemeanor) with id. $\S 210.3(1)$ (a) (manslaughter is a second degree felony).

305. See note 248 supra. 
tempted reckless endangerment, that is, attempting to engage in riskcreating conduct, would be more appropriate in this case.

A definition of attempt reflecting element analysis and avoiding the unnecessary three-subsection approach of the Model Penal Code might be drafted as follows:

\section{Definition of Attempt}

(1) An actor is guilty of an attempt to commit an offense if, acting with the culpability required for commission of the offense, he engages ${ }^{306}$ in conduct that would constitute the offense or a substantial step toward completion of the offense if the circumstances were as he believes or hopes them to be.

(2) When causing a particular result is an element of the offense, the actor, to be liable under Subsection (1), must have acted with the purpose of causing or with the belief that his conduct will cause such result. 307

To avoid any possible questions, a subsection could be added to expressly provide that an actor who believes that he has completed the conduct constituting the offense, or believes that he has completed the last act needed to cause the criminal result, has satisfied the substantial step requirement of the definition. ${ }^{308}$

\section{E. Element Analysis in Conspiracy}

An element analysis of Model Penal Code section 5.03(1), ${ }^{309}$ which defines conspiracy, reveals many ambiguities concerning issues central to the definition of the requirements for conspiracy liability. The objective elements present little difficulty. The defendant need not satisfy the objective elements of the offense, i.e., commit the of-

306. The "purposely" language is omitted as unnecessary. See notes 289-98 supra and accompanying text.

307. The Model Penal Code's omission language ("does or omits to do anything") in its attempt provision is omitted here and later in the sentence. The Code generally intends conduct to include both acts and omissions. See MODEL PEnAL CoDE $\$ 1.13$ (5) (Proposed Official Draft 1962) ("conduct" defined as an act or omission). Technically, the Code's solu. tion is not an adequate one because the term "conduct" is not always used as it is here. See 1 P. ROBINSON, supra note $253, \$ 86$ (c)(1).

308. The Model Penal Code has a provision describing in greater detail what may be held to constitute a substantial step. See MODEL PENal CODE $\$ 5.01$ (2) (Proposed Official Draft 1962). This proposed subsection could easily be added to that provision.

309. Section 5.03(1) defines conspiracy as follows:

A person is guilty of conspiracy with another person or persons to commit a crime if, with the purpose of promoting or facilitating its commission, he:

(a) agrees with such other person or persons that they or one or more of them will engage in conduct which constitutes such crime or an attempt or solicitation to commit such crime....

Id. $§ 5.03(1)$. 
fense. Nor must any member of the conspiracy do so. Conspiracy can therefore be used to punish preparatory conduct. The required conduct consists of the agreement that one or more of the conspirators will commit the offense and an overt act by one of the conspirators in pursuance of the conspiracy. ${ }^{310}$ The overt act element, which is sometimes said to be an evidentiary rather than a substantive element, ${ }^{311}$ is not always required. ${ }^{312}$

The agreement requirement deserves special explanation. Traditional case law required that both members of a two-member conspiracy agree. An "agreement" was necessarily bilateral. That is, for the defendant to be convicted of conspiracy, his co-conspirator had to have agreed with him. ${ }^{313}$ Under the Model Penal Code's subjective view of criminality, an actor's liability should be determined on the basis of his own view of things. Thus, the drafters expressly adopted a unilateral concept of agreement, requiring only that the defendant believe that he has entered into an agreement with the coconspirator. ${ }^{314}$ Perhaps to reflect this unilateral agreement concept,

310. Boxes 4, 5, and 6 of Chart V1, Appendix, summarize these objective requirements.

311. See Hyde v. United States, 225 U.S. 347, 388 (1912) (Holmes, J., dissenting) (The overt act is simply evidence that the conspiracy has passed beyond words; it is no more a part of the offense than is the fact that the prosecution is initiated within the period of the statute of limitations.). The Hyde majority, however, viewed the requirement as an element of the offense. Id. at 359. Others contend that the overt act has substantive significance reflecting the well-established doctrine that an act is required and that one is not punishable for evil thoughts alone; those who view the act as an evidentiary device find satisfaction of the act requirement in the criminal agreement. See MOdel Penal Code $\$$ 5.03(5), comment at 141 (Tent. Draft No. 10, 1960). See generally W. LAFave \& A. ScotT, supra note 7, § 62, at 476-79.

312. See, e.g., State v. LaPlume, 118 R.I. 670, 677, 375 A.2d 938, 941 (1977) (overt act is not an element of conspiracy). Contra TENN. CODE ANN. § 39-1102 (1975) (abrogating common law rule and requiring an overt act); cf. N.J. STAT. ANN. $\S 2$ C:5-2(d) (West 1982) (same); Model Penal Code \$ 5.03(5) (Proposed Official Draft 1962) (overt act not required for a conspiracy to commit a felony of the first or second degree).

313. See, e.g., Archbold v. State, - Ind. - 397 N.E.2d 1071 (1979) (co-conspirator was police officer who lacked criminal intent; the requisite intent was therefore not established); Regle v. State, 9 Md. App. 346, 264 A.2d 119 (Ct. Spec. App. 1970) (insanity of sole coconspirator precluded the agreement necessary for the crime); Regina v. O'Brien [1955] 2 D.L.R. 311,312 (Can.) (Since one of the conspirators did not have the intention to carry out the crime, he could not be a party to the conspiracy, and therefore his co-conspirator "could not alone be found guilty of the crime"); $f$. Garcia v. State, 271 Ind. 510,394 N.E.2d 106 (1979) (applying the unilateral standard for conspiracy under the new Indiana code, IND. Code ANN. § 35-41-5-2 (West 1978)). See generally Model Penal Code § 5.03(1) comment 2, at 104 (Tent. Draft No. 10, 1960).

314. The co-conspirator's intention to agree is irrelevant. The defendant "has conspired, within the meaning of the definition, in the belief that the other party was with him " Model Penal Code $\$ 5.03(1)$ comment 2, at 105 (Tent. Draft No. 10, 1960); see People v. Schwimmer, 66 A.D.2d 91, 411 N.Y.S.2d 922 (App. Div. 1978) (holding that under 
section 5.03(1)(a) defines an actor's liability for conspiracy by requiring that he "agree [ ] with such other person or persons," rather than following the more traditional form of defining conspiracy, which would require that "two or more persons" agree. ${ }^{315}$ Model Penal Code section 5.04 also furthers this unilateral view of conspiracy by eliminating a defense based on a co-conspirator's nonliability. ${ }^{316}$

The culpability requirements, again, present the greatest difficulty in the definition of conspiracy. Certain state of mind elements are implicit in the agreement requirement noted above. The term "agree" is commonly understood to include an "intent to agree." 317

The requirement that the defendant "agree[ ] with [others] that ... one . . . of them will engage in conduct which constitutes such crime" might be interpreted as requiring that the defendant have some culpable state of mind as to the substantive offense. The provision, however, does not specify whether the conspirator must agree as to just the bare conduct or must also agree as to the circumstances and result that make such conduct criminal. While the law rarely requires that an actor know that his conduct is criminal, ${ }^{318}$ many of the purposes of criminal liability and punishment would seem at least to demand that an actor know or have strong cause to know of the circumstances or results that make the conduct criminal. ${ }^{319}$ Of course, each of these circumstances and results may not require knowledge but rather simply the culpability level sufficient to establish liability for the substantive offense. The commentary to the Model Penal Code provision recognizes that requiring something less than knowledge of a circumstance may be appropriate where the substantive offense requires less than knowledge of the attendant circumstances. ${ }^{320}$ As to precisely what is required, however, the com-

New York's unilateral approach to conspiracy, the individual's belief in agreement is sufficient to establish that element), aff $d, 47$ N.Y.2d 1004, 394 N.E.2d 288, 420 N.Y.S.2d 218 (1979).

315. Model Penal Code $\S 5.03(1)$ (a) (Proposed Official Draft 1962) (emphasis added). Compare id. and N.J. STAT. ANN. $\$ 2$ C:5-2(a)(1) (West 1982) (both using the phrase "he agrees with" another person) with 18 U.S.C. $\$ \S 23,84,241,351$ (d) (1976) and R.I. GEN. LAWS $\S 11-43-13$ (1981) (all using the phrase "two or more persons" agree or conspire).

316. Model Penal Code $\S 5.04(1)$ (a)-(b) (Proposed Official Draft 1962).

317. See, e.g., Regina v. O'Brien, [1955] 2 D.L.R. 311,313 (Can.) ("It is, of course, essential that the conspirators have the intention to agree . . . .") (italics omitted)). This requirement is stated in Box 1 of Chart VI, Appendix.

318. See, e.g., Model Penal Code $\$ 2.09$ (Proposed Official Draft 1962).

319. One who has no reason to be aware of the circumstances or results rendering the conduct criminal is neither deterrable nor blameworthy. Nor is there any special deterrent or rehabilitative purpose to be served, since there is no reason to think that the offense will recur.

320. The commentary provides that: 
mentary admits that the "Draft does not attempt to solve the problem by explicit formulation . . . but affords sufficient flexibility for satisfactory decision as such cases may arise. [W] think it wise to leave the issue to interpretation." 321 But such an approach to defining criminal liability can be criticized for providing somewhat less than the legality principle demands. ${ }^{322}$ The ambiguous language of the conspiracy provision coupled with the ambivalent language of the commentary indicates a need for clarification, which the interpretation recommended here can provide.

Model Penal Code section 5.03(1) requires that the defendant have entered the conspiracy (by "agree[ing] with [co-conspirators]") "with the purpose of promoting or facilitating" the commission of the offense that is the objective of the conspiracy. ${ }^{323}$ Like the section's "agrees with [others] that . . . one . . . of them will engage in conduct which constitutes such crime" language, this requirement also states an independent element that may imply that some of the culpability requirements of the object offense are required as well. For example, to require that the conspirator have "the purpose of promoting . . . commission [of the offense]" may mean that the conspirator must consciously desire the circumstances or the results that make the substantive offense criminal. But, as with attempt liability, requiring purpose as to all elements of the substantive offense seems

\footnotetext{
Although the agreement must be made "with the purpose of promoting or facilitating" the commission of the crime, we think it strongly arguable that such a purpose may be proved although the actor did not know of the existence of a circumstance which does exist in fact, when knowledge of the circumstance is not required for the substantive offense.

Model Penal Code $\S 5.03(1)$ comment 2, at 113 (Tent. Draft No. 10, 1960).

321. Id.

322. See notes 95-98 supro and accompanying text.

323. Box 1 of Chart VI, Appendix, reflects this requirement. There has been considerable dispute over whether this conspiratorial purpose may be inferred from an actor's knowledge of the illicit object of the conspiracy. In United States v. Falcone, 311 U.S. 205 (1940), the Supreme Court held that knowledge of a purchaser's illegal use of a product was insufficient to establish an inference of intent to facilitate a conspiracy. Id. at 208-10. In Direct Sales Co. v. United States, 319 U.S. 703 (1943), however, the Court held that proof of the sale of large quantities of controlled substances for profit with knowledge of the illicit distribution of those substances was sufficient to to establish the intent required for conspiracy. In People v. Lauria, 251 Cal. App. 2d 471, 59 Cal. Rptr. 628 (1967), the court held that knowledge of the illicit object combined with either proof of a special interest in the success of that criminal object or proof of a particularly aggravated object was sufficient to give rise to an inference of the requisite intent. Id. at $482,59 \mathrm{Cal}$. Rptr. at 635 . While this dispute deals only with a matter of proof rather than the formal requirements of liability, it is analogous to the substantive dispute over whether purposeful or knowing assistance should be required for accomplice liability. For a discussion of the complicity issue, see notes 259-60 supra and accompanying
text.
} 
indefensible as a policy matter. Conspiracy to commit statutory rape would require that the conspirators be aware of or desire that the woman be under the prescribed age. ${ }^{324}$ One who was aware of a substantial risk of the existence of that circumstance would have a defense. $^{325}$ In order to prevent this effect, this "purpose" requirement should apply only to the conduct element; only the level of culpability required by the object offense should be required as to circumstance and result elements. ${ }^{326}$

As was the case in attempt liability, it may well be appropriate to require a higher culpability as to a result element than is required by the object offense, at least if the object offense never occurs. In other words, no liability should attach for an unsuccessful conspiracy to commit those crimes that require only recklessness or less as to their result for the same reasons that no liability should attach for attempt to commit crimes that require only recklessness or less as to their result. ${ }^{327}$ For example, when a conspiracy contemplates conduct that creates a risk of death but no death occurs, it is more appropriately treated as a conspiracy to commit reckless endangerment than as a conspiracy to commit reckless homicide. But when the proscribed result does occur-as it never does in the attempt context-conspiracy to commit reckless homicide is appropriate. ${ }^{328}$ Mine owners who conspire to create a substantial and unjustified risk of death to miners in order to save money, should, if a miner actually dies, incur liability for conspiracy to commit reckless homicide. ${ }^{329}$

324. See Model Penal Code § 2.02(2)(a)(ii) (Proposed Official Draft 1962) (defining "purposeful" as to a circumstance); text accompanying note 66 supra. For a discussion of the raising of the culpability requirements as to circumstance above that required by the offense definition in the context of attempt, see notes 293-95 supra and accompanying text.

325. Model Penal Code $\$ 2.02(2)$ (c) (Proposed Official Draft 1962) (defining "recklessness" as to a circumstance); text accompanying note 74 supra. Thus, the actor could not be convicted of conspiracy to commit the substantive offense of statutory rape even though he was more culpable as to the victim's age than is required by the offense definition.

326. These conclusions are reflected in Box 2 of Chart VI, Appendix.

327. For a discussion of attempts to commit crimes requiring recklessness as to a result, see notes 304-05 supra and accompanying text. Case law supports a similar limitation for conspiracy. See, e.g., People v. Hamp, 110 Mich. App. 92, 312 N.W.2d 175 (1981) (one cannot conspire to commit second degree murder; conspiracy requires intent to promote a plan and a plan requires foreknowledge).

328. This conclusion is reflected in Box 2 of Chart VI, Appendix.

329. While many jurisdictions prohibit conviction for both the object offense and conspiracy, see, e.g., Model Penal Code $\S 1.07(1)(a)$, (4)(b) (Proposed Official Draft 1962), many others permit conviction for both, see, e.g., People v. Steele, 193 Colo. 187, 563 P.2d 6 (1977) (conviction of murder and conspiracy to commit murder permitted); Commonwealth v. Torbeck, $266 \mathrm{~Pa}$. Super. 535, 405 A.2d 948 (1979) (conspiracy does not merge with substantive offenses); State v. Leonardo, 119 R.I. 17, 375 A.2d 1338 (1977) (convictions for second 
The language of section 5.03(1) gives little guidance in determining the culpability requirements for conspiracy, especially with respect to the culpability required as to the object offense. ${ }^{330}$ On these culpability issues, the conspiracy provision fails miserably to implement element analysis.

Under Model Penal Code provision 5.04(1)(b), the defendant's liability does not depend upon a co-conspirator's culpability. ${ }^{331}$ This is contrary to the common law rule, which requires that at least one other conspirator be convictable, ${ }^{332}$ but is consistent with the Code's subjective view of criminality.

The following formulation would resolve most of the issues raised by the preceding element analysis of the Model Penal Code conspiracy provision:

\section{Definition of Conspiracy}

(1) An actor is guilty of conspiracy ${ }^{333}$ to commit a crime if, acting with the culpability required for commission of the object of-

degree murder and conspiracy to commit murder permitted); Bell v. Commonwealth, 220 Va. 87, 255 S.E.2d 498 (1978) (conspiracy conviction does not merge with the substantive offense); LA. Rev. Stat. ANN. \$ 14.26(a) (West Supp. 1982) (conviction for either conspiracy or the completed offense does not bar prosecution of the other).

330. The Model Penal Code attempt provision at least had a special subsection to deal with the result element problem. See notes 299-302 supra and accompanying text.

331. Model Penal Code § 5.04(1)(b) (Proposed Official Draft 1962); see, e.g., People v. Schwimmer, 66 A.D.2d 91, 411 N.Y.S.2d 922 (App. Div. 1978) (defendant could be convicted under New York's unilateral conspiracy statute even though his two co-conspirators were a police officer and an informant), affd, 47 N.Y.2d 1004, 394 N.E.2d 288, 420 N.Y.S.2d 218 (1979). The Model Penal Code's rejection of a defense based on a co-conspirator's lack of culpability could be more comprehensive, however. See 1 P. ROBINSON, supra note 253, $\S$ 82(e), (f)(2). Compare Model Penal Code $\S 5.04(1)$ (b) (Proposed Official Draft 1962) (rejecting the unconvictable confederate defense for conspiracy) with id. $\$ 2.06$ (7) (rejecting the unconvictable confederate defense for complicity).

This rule is reflected in Box 3 of Chart VI, Appendix.

332. See Martinez v. People, 129 Colo. 94, 267 P.2d 654 (1954) (defendant cannot be convicted of conspiracy if the only ather conspirator is acquitted; therefore, judge's charge to the jury instructing it to find both defendants either guilty of conspiracy or innocent was approved); State v. Littlejohn, 264 N.C. 571, 142 S.E.2d 133 (1965) (if all other conspirators are acquitted, one lone conspirator cannot be convicted); State v. McElray, 71 R.I. 379,46 A.2d 397 (1946) (plea of nolo contendre by co-conspirator amounts to a guilty plea; defendant's conspiracy conviction may therefore stand); State v. Jackson, 7 S.C. 283 (1876) (effect of nolle prosequi as to one of two indicted coconspirators is to leave an indictment charging only one conspirator, which cannot stand); KY. REV. STAT. § 506.070(3) (1975) ("[a] defendant cannot be convicted of conspiracy if all of his co-conspirators have been acquitted or discharged under circumstances amounting to an acquittal"). See generally Cousens, Agreement as an Element in Conspiracy, 23 VA. L. REV. 898 (1937).

333. The Model Penal Code phrase "conspiracy with another person or persons," MODEL Penal Code § 5.03(1) (Proposed Official Draft 1962) (emphasis added), is dropped as being inconsistent with the unilateral view of conspiracy that is demanded by the Code's subjective view of criminality. 
fense, he agrees with another person or persons that one or more of them will engage in conduct that would, under the circumstances as he believes them to be ${ }^{334}$ constitute such crime or an attempt or solicitation to commit such crime.

(2) When causing a particular result is an element of the object offense and such result does not occur, the actor, to be liable for conspiracy under Subsection (1), must have the purpose or belief that the conduct contemplated by the agreement will cause such result.

\section{SUMMARY AND CONCLUSION}

The early common law's vague notion of "wickedness" gradually gave way to a requirement of a specific state of mind for criminal liability. The concept of mens rea inevitably meant a different state of mind for each offense-mentes reae. But even more profound was the subsequent Model Penal Code innovation that replaced this "offense analysis" approach with an approach recognizing that different objective elements of an offense could have different accompanying culpable state of mind requirements. This modern "element analysis" approach provides, for the first time, a statement of the minimum requirements for liability that is sufficiently clear and precise to satisfy the demands of the legality principle. Because element analysis comprehensively defines liability, it permits legislatures to properly reclaim from the courts the authority to define criminal offenses.

Despite these recent dramatic developments, most American courts have failed to take note of the modern criminal code shift to element analysis. Dulled by generations of offense analysis, courts ignore general code provisions that, together with offense definitions, define every objective and culpability element required for liability. They continue to rely upon their judge-made law of mistake and accident, properly rendered obsolete by modern culpability schemes, and continue to define unstated culpability requirements according to their own view of the public policy interests. The result is that in nearly every criminal case in the United States the statement of the

334. The phrase "under the circumstances as he believes them to be" is added to punish an impossible conspiracy to commit a crime, just as impossible attempts are punished. See note 281 supra and accompanying text. While it is not apparent from the face of the statute, this result is intended by the Model Penal Code drafters. See MODEL PENAL Code $\$ 5.05$ comment 3, at $179 \mathrm{n} .26$ (Tent. Draft No. 10, 1960) ("'s]ince Section 5.03(1) treats conspiracy to.attempt the commission of a crime as a conspiracy to commit that crime, it carries the attempt solution [to impossibility] over to conspiracy"). It is also demanded by the Code's
subjective view of criminality. 
law defining the offense charged suffers a significant risk of inaccuracy.

While it does not explain or excuse the slow judicial re-education, the Model Penal Code's implementation of element analysis is admittedly haphazard and, in many respects, seriously flawed. So too are the criminal codes of most states, modeled as they are after the Code. Yet the virtues of element analysis make it worth salvaging; the feasibility of such a task is confirmed by the proposals made here for revised statutes governing the definition of offenses and revised formulations of complicity, attempt, and conspiracy, the major general provisions imposing liability. 
Appendix: Element Analysis Summaries

Chart III: Causing Crime by an Innocent, Model Penal Code Section 2.06(2)(a) .................... 759

Chart IV: Accomplice Liability, Model Penal Code Section 2.06(3) (a)(ii) ........................... 760

Chart V: Definition of Attempt, Model Penal Code Section $5.01(1) \ldots \ldots \ldots \ldots \ldots \ldots \ldots \ldots \ldots \ldots \ldots . \ldots . \ldots . \ldots 1$

Chart VI: Definition of Conspiracy, Model Penal Code Section $5.03(1) \ldots \ldots \ldots \ldots \ldots \ldots \ldots \ldots \ldots \ldots \ldots 2$

Chart III: Element Analysis of Model Penal Code $\$ 2.06(2)(\mathrm{a})$, Causing Crime by an Innocent

Liability of the defendant for causing crime by an innocent requires proof of:

\begin{tabular}{|c|c|c|c|}
\hline & $\begin{array}{c}\text { Additional } \\
\text { Elements by } \\
\text { Defendant }\end{array}$ & $\begin{array}{l}\text { Elements of the } \\
\text { Substantive } \\
\text { Offense by } \\
\text { Defendant } \\
\end{array}$ & $\begin{array}{c}\text { Elements by } \\
\text { Innocent }\end{array}$ \\
\hline $\begin{array}{l}\text { Culpability } \\
\text { Elements }\end{array}$ & $\begin{array}{l}\text { reckless as to } \\
\text { causing conduct } \\
\text { of innocent (?) } \\
(\S 2.02(3))\end{array}$ & $\begin{array}{l}\text { "with the kind of } \\
\text { culpability that is } \\
\text { sufficient for } \\
\text { commission of the } \\
\text { offense" } \\
(\$ 2.06(2)(a))\end{array}$ & \begin{tabular}{l}
\multicolumn{1}{c}{ none } \\
("innocent or \\
irresponsible," \\
$\S 2.06(2)(\mathrm{a})$ )
\end{tabular} \\
\hline $\begin{array}{l}\text { Objective } \\
\text { Elements }\end{array}$ & $\begin{array}{l}4 / \text { "causes an } \\
\text { innocent ... to } \\
\text { engage in [the] } \\
\text { conduct } \\
\text { [constituting the } \\
\text { offense]" (?) } \\
(\$ 2.06(2)(a))\end{array}$ & none & $\begin{array}{l}6 \\
\text { conduct } \\
\text { [constituting the } \\
\text { offense] (?) } \\
(\$ 2.06(2)(a))\end{array}$ \\
\hline
\end{tabular}

The material in Chart III is discussed at the text accompanying the following notes:

Box 1 - notes 238-42

Box 2 - notes 234-37

Box 3 - notes 243-45

Boxes 4, 5, and 6 - notes $232-33$ 
Chart IV: Element Analysis of Model Penal Code $\$ 2.06(3)$ (a)(ii), Accomplice Liability

Accomplice liability of the defendant requires proof of:

\begin{tabular}{|c|c|c|c|}
\hline & $\begin{array}{c}\text { Additional } \\
\text { Elements by } \\
\text { Defendant }\end{array}$ & $\begin{array}{c}\text { Elements of the } \\
\text { Substantive } \\
\text { Offense by } \\
\text { Defendant } \\
\end{array}$ & $\begin{array}{l}\text { Elements by } \\
\text { Perpetrator }\end{array}$ \\
\hline $\begin{array}{l}\text { Culpability } \\
\text { Elements }\end{array}$ & $\begin{array}{l}\text { "with the purpose } \\
\text { of promoting or } \\
\text { facilitating the } \\
\text { commission of the } \\
\text { offense" } \\
(\S 2.06(3)(a))\end{array}$ & $\begin{array}{l}\text { culpability as to } \\
\text { result as required } \\
\text { by substantive } \\
\text { offense }(\S 2.06(4)) \\
\text { culpability as to } \\
\text { circumstance } \\
\text { elements as } \\
\text { required by } \\
\text { substantive } \\
\text { offense (?) }\end{array}$ & $\begin{array}{c}\text { none } \\
(\S 2.06(7))\end{array}$ \\
\hline $\begin{array}{l}\text { Objective } \\
\text { Elements }\end{array}$ & $\begin{array}{l}\text { "aids or agrees or } \\
\text { attempts to aid } \\
\text { [the perpetrator] } \\
\text { in planning or } \\
\text { committing [the } \\
\text { offensel" } \\
(\S 2.06(3)(\mathrm{a})(\mathrm{ii}))\end{array}$ & none & $\begin{array}{l}\text { "proof of } \\
\text { commission of the } \\
\text { offense" } \\
(\S 2.06(7))\end{array}$ \\
\hline
\end{tabular}

The material in Chart IV is discussed at the text accompanying the following notes:
Box 1 - notes 256-61
Box 2 - notes 262-74
Box 3 - notes 275-77
Box 4 - notes 246-50
Box 5 - note 246
Box 6 - notes 251-55 
Chart V: Element Analysis of Model Penal Code \$ 5.01(1), Definition of Attempt

Liability of the defendant for an attempt requires proof of:

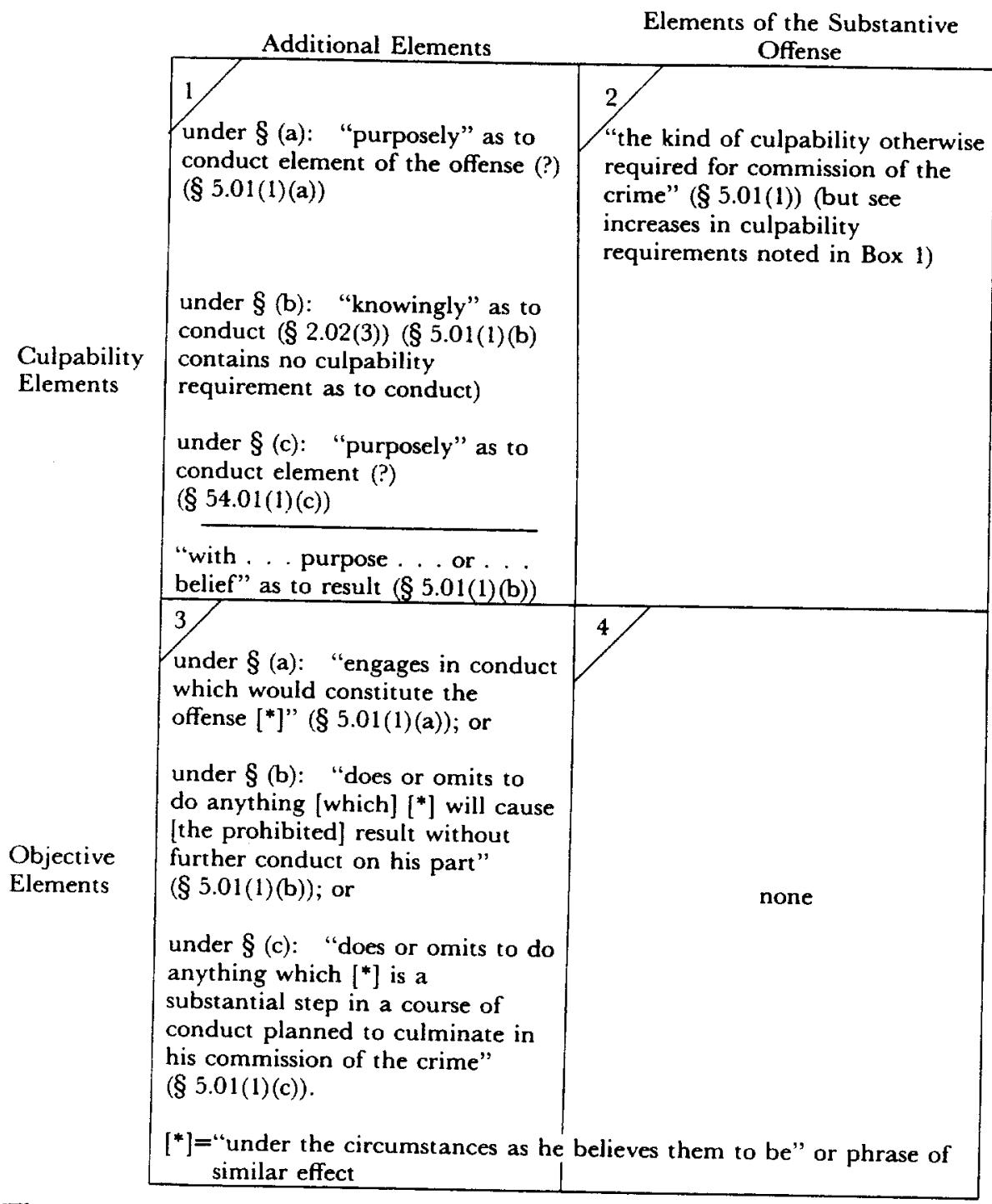

The material in Chart $\mathrm{V}$ is discussed at the text accompanying the following notes:
Box 1 - notes 288-305
Box 2 - notes 285-87
Box 3 - notes 280-84
Box 4 - note 280 
Chart VI: Element Analysis of Model Penal Code $\$ 5.03(1)$,

\section{Definition of Conspiracy}

Liability of the defendant for conspiracy requires proof of:

\begin{tabular}{|c|c|c|c|}
\hline & $\begin{array}{c}\text { Additional Elements } \\
\text { by Defendant }\end{array}$ & $\begin{array}{c}\text { Elements of the } \\
\text { Object Offense by } \\
\text { Defendant }\end{array}$ & $\begin{array}{c}\text { Elements by Co- } \\
\text { Conspirators }\end{array}$ \\
\hline & $\begin{array}{l}\text { intention to agree } \\
\text { (implicit in objective } \\
\text { requirement of } \\
\text { agreement) }\end{array}$ & $\begin{array}{l}\text { "purposely" as to } \\
\text { conduct element of } \\
\text { object offense(?) } \\
(\S 5.03(1))\end{array}$ & $\begin{array}{l}\text { none } \\
\text { (defense of co- } \\
\text { conspirator does not }\end{array}$ \\
\hline $\begin{array}{l}\text { Culpability } \\
\text { Elements }\end{array}$ & $\begin{array}{l}\text { "with the purpose of } \\
\text { promoting or } \\
\text { facilitating [the] } \\
\text { commission [of an } \\
\text { offense]" ( } \$ 5.03(1)) \\
\text { (see Box } 2 \text { for }\end{array}$ & $\begin{array}{l}\text { "knowing" as to } \\
\text { result element if } \\
\text { result does not occur; } \\
\text { culpability as to } \\
\text { result as required by } \\
\text { object offense if result } \\
\text { does occur (?) }\end{array}$ & defendant, $\S 5.04(1))$ \\
\hline & purpose requirement) & $\begin{array}{l}\text { culpability as to } \\
\text { circumstance } \\
\text { elements as required } \\
\text { by object offense(?) }\end{array}$ & \\
\hline $\begin{array}{l}\text { Objective } \\
\text { Elements }\end{array}$ & $\begin{array}{l}\text { "agrees with [co- } \\
\text { conspirators] that } \\
\text { will engage in } \\
\text { conduct which } \\
\text { constitutes such }\end{array}$ & none & $\begin{array}{l}\text { "overt act in } \\
\text { pursuance of . . . } \\
\text { conspiracy" (by any } \\
\text { conspirator) } \\
(\S 5.03(5))\end{array}$ \\
\hline & crime" $(\S 5.03(1)(\mathrm{a}))$ & & $\begin{array}{l}\text { (co-conspirator need } \\
\text { not agree) }\end{array}$ \\
\hline & & & $\begin{array}{l}\text { (defense of co- } \\
\text { conspirator does not } \\
\text { provide a defense to } \\
\text { defendant, } \S 5.04(1) \text { ) }\end{array}$ \\
\hline
\end{tabular}

The material in Chart VI is discussed at the text accompanying the following notes:

Box 1 - notes 317,323

Box 2 - notes $318-30$

Box 3 - notes 331-32

Box 4 - notes $310,313-16$

Boxes 5 and 6 - notes $310-12$ 